\title{
A Summary Description of the Flammable Gas Tank Safety Program
}

\author{
G. D. Johnson \\ D. J. Sherwood
}

Date Published

October 1994

Prepared for the U.S. Department of Energy Office of Environmental Restoration and Waste Management

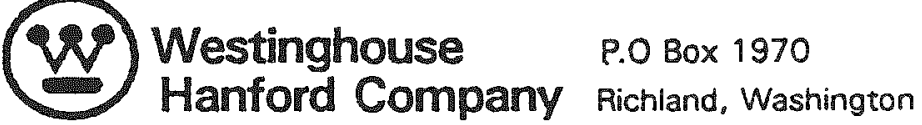

Hanford Operations and Engineering Contractor for the

U.S. Department of Energy under Contract DE-ACO6-87RL10930

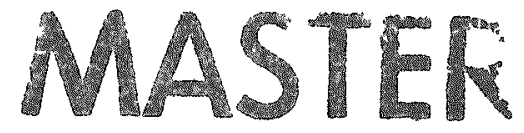

Approved for Public Release 


\section{DISCLAIMER}

This report was prepared as an account of work sponsored by an agency of the United States Government. Neither the United States Government nor any agency Thereof, nor any of their employees, makes any warranty, express or implied, or assumes any legal liability or responsibility for the accuracy, completeness, or usefulness of any information, apparatus, product, or process disclosed, or represents that its use would not infringe privately owned rights. Reference herein to any specific commercial product, process, or service by trade name, trademark, manufacturer, or otherwise does not necessarily constitute or imply its endorsement, recommendation, or favoring by the United States Government or any agency thereof. The views and opinions of authors expressed herein do not necessarily state or reflect those of the United States Government or any agency thereof. 


\section{DISCLAIMER}

Portions of this document may be illegible in electronic image products. Images are produced from the best available original document. 



\section{EXECUTTVE SUMMARY}

Radioactive liquid waste may produce hydrogen as a result of the interaction of gamma radiation and water. In tanks containing organic chelating agents, additional hydrogen gas as well as nitrous oxide and ammonia may be produced by thermal and radiolytic decomposition of these organics. Several high-level radioactive liquid waste storage tanks, located underground at the Hanford Site in Washington State, are on a Flammable Gas Watch List. Some contain waste that produces and retains gases until large quantities of gas are released rapidly to the tank vapor space. Tanks nearly filled to capacity have relatively little vapor space; therefore if the waste suddenly releases a large amount of hydrogen and nitrous oxide, a flammable gas mixture could result. The most notable example of a Hanford waste tank with a flammable gas problem is tank 241-SY-101. Upon occasion, waste stored in this tank has released enough flammable gas to burn if an ignition source had been present inside of the tank. Several other Hanford waste tanks exhibit similar behavior although to a lesser magnitude. Because this behavior was not adequately addressed in safety analysis reports for the Hanford Tank Farms, an unreviewed safety question was declared, and in 1990, the Flammable Gas Tank Safety Program was established to address this problem. The purposes of the program are as follows:

1. : Provide safety documents to fill gaps in the safety analysis reports.

2. Resolve the safety issue by acquiring knowledge about gas retention and release from radioactive liquid waste and developing mitigation technology.

This document provides the general logic and work activities required to resolve the unreviewed safety question and the safety issue. 
This page intentionally left blank. 
CONTENTS

1.0 BACKGROUND ................................ . . . . .

2.0 THE SAFETY ISSUE $\ldots \ldots \ldots \ldots \ldots \ldots \ldots \ldots \ldots \ldots \ldots . \ldots \ldots \ldots$

3.0 FLAMMABLE GAS TANK SAFETY ISSUE RESOLUTION . . . . . . . . . 3-1

3.1 EVALUATING THE PROBLEM . . . . . . . . . . . . . . . 3-1

3.2 IMPLEMENTING THE ZERO OPTION $\ldots \ldots \ldots \ldots \ldots \ldots . \ldots . . . . .3-\ldots$

3.3 IMPLEMENTING MTTIGATION . . . . . . . . . . . . . . . . . . . . . . 3-9

3.4 IMPLEMENTING THE RESOLUTION . . . . . . . . . . . . . . . . . . . 3-9

4.0 PROGRAM ACTIVTTIES ....................... . . . .

4.1 CHARACTERIZATION AND EVALUATION ........... 4-3

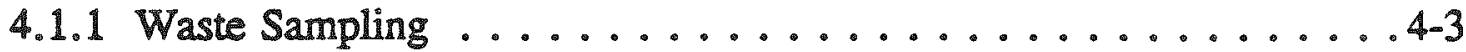

4.1.2 Gas Monitoring .................... . . . . . .

4.1.3 Evaluating Waste Behavior .............. 4-12

4.2 TECHNOLOGY ......................... . . . . . . . . . . . .

4.2.1 Laboratory Studies .................... 4-13

4.2.2 Developing Tank Model Applications . . . . . . . . . . . . 4-16

4.2.3 Developing Techniques for Characterizing

Chelators and Chelator Fragments . . . . . . . . . . . 4-16

4.2.4 Developing Sampling Techniques ............ . 4-17

4.3 SAFETY DOCUMENTATION AND UNREVIEWED

SAFETY QUESTION RESOLUTION . . . . . . . . . . . . . . 4-18

4.4 EQUIPMENT AND INSTRUMENTATION UPGRADES . . . . . . . . . . 4-19

4.4.1 Ventilation Upgrades . . . . . . . . . . . . . . . . 4-23

4.4.2 Farm Tank Monitor and Control System . . . . . . . . . 4-23

4.4.3 Gas Monitoring . . . . . . . . . . . . . . . 4-23

4.4.4 Temperature Measurement . . . . . . . . . . . . . . . 4-24

4.4.5 Waste Surface Level Measurement Upgrade . . . . . . . . . . . . 4-24

4.5 MTtigation . . . . . . . . . . . . . . . . . . . . . . . . . . . . . 4-24

4.6 RELATIONSHIP BETWEEN WORK ACTIVITIES AND PROGRAM LOGIC . . . . . . . . . . . . . . . . 4 4-25

5.0 PROGRAMMATIC WORK PRIORITY $\ldots \ldots \ldots \ldots \ldots \ldots$. . . . . . . .

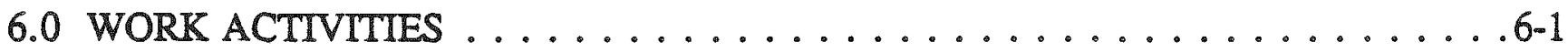

7.0 REFERENCES .............................

APPENDIX A PROGRAM DRIVERS . . . . . . . . . . . . . A A-1 


\section{LIST OF FIGURES}

3-1 Flammable Gas Tank Safety Issue Resolution Logic . . . . . . . . . . . . . . . 3-2

3-2 Level 2 Logic Diagram for 1.0 Evaluate the Problem . . . . . . . . . . . . . 3-3

3-3 Level $3 / 4$ Logic Diagram for 1.0 Evaluate the Program . . . . . . . . . . . . 3-4

3-4 Level 3/4 Logic Diagram for 3.0 Implement Mitigation . . . . . . . . . . . 3-6

3-5 Level 3/4 Logic Diagram for 4.0 Implement Resolution . . . . . . . . . . . . 3-7

3-6 Level 2 Logic Diagram for 2.0 Implement Zero Option . . . . . . . . . . . 3-8

3-7 Level 2 Logic Diagram for 3.0 Implement Mitigation . . . . . . . . . . . . . 3-10

3-8 Level 3/4 Logic Diagram for 3.0 Implement Mitigation . . . . . . . . . . . 3-11

3-9 Level 2 Logic Diagram for 4.0 Implement Resolution . . . . . . . . . . . . 3-12

3-10 Level 3/4 Logic Diagram for 4.0 Implement Resolution . . . . . . . . . . . 3-13

4-1 Hydrogen Monitoring System (Closed Cabinet) . . . . . . . . . . . . . 4-9

4-2 Hydrogen Monitoring System (Open Cabinet) . . . . . . . . . . . . 4-11

4-3 Universal Sampler . . . . . . . . . . . . . . . . . . . 4-20

$4-4$ Operation of the Universal Sampler $(1$ of 2$) \ldots \ldots \ldots \ldots \ldots . \ldots . \ldots .21$

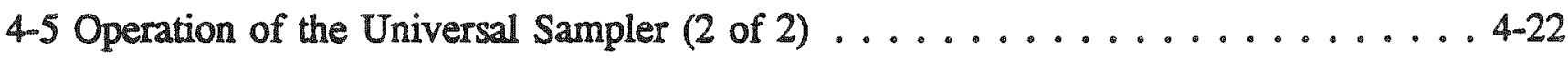




\section{LIST OF TABLES}

1-1. Minimum Volume Percent of Gas in Air Capable of Supporting Combustion (Lower Flammability Limit) . . . . . . . . . . . . . . . . . 1-1

2-1 Flammable Gas Watch List Tanks ... . . . . . . . . . . . . 2-1

4-1 Data Requirements $\ldots \ldots \ldots \ldots \ldots \ldots \ldots \ldots \ldots . \ldots \ldots . . \ldots \ldots$

$4-2$ Core Sample Analyses $\ldots \ldots \ldots \ldots \ldots \ldots \ldots \ldots \ldots . . . . . . . .64$

4-3 Data Priority and Uncertainties for Retained Gas

Sampler System . . . . . . . . . . . . . . . . . . . . . . 4-18

4-4 Mitigation Options ........................ . . . . . . .

4-5 Relationship of Work Activities and Program Logic . . . . . . . . . . . . 4-30

5-1 Double-Shell Tank Ranking $\ldots \ldots \ldots \ldots \ldots \ldots \ldots \ldots \ldots . \ldots \ldots$

5-2 Scoring Double-Shell Tanks for Work Prioritization . . . . . . . . . . 5-2

$5-3$ Single-Shell Tank Ranking . . . . . . . . . . . . . . . . 5-3

5-4 Scoring Single-Shell Tanks for Work Prioritization . . . . . . . . . . . . 5-4

5-5 Summary of Hanford High-Level Radioactive

Liquid Waste Tanks . . . . . . . . . . . . . . . . . . . . 5-5

5-6 Scheduled Activities for the Flammable Gas Tank Safety Program . . . . . . . . . . . . . . . . . . . 5 5-

6-1 Work Activities for the Flammable Gas Tank Safety Program 


\section{LIST OF TERMS}

DNESB

DOE

LFL

MIT

SHMS

TMACS

UFL

USQ
Defense Nuclear Facilities Safety Board

U.S. Department of Energy

lower flammability limit

multi-function instrument tree

Standard Hydrogen Monitoring System

Tank Monitor and Control System

upper flammability limit

unreviewed safety question 


\subsection{BACKGROUND}

Potentially dangerous gases are often evolved from industrial processes. The primary hazards associated with small levels of gas are toxicity and combustion. Regular inspection of storage facilities, proper work controls and procedures, and adequate ventilation ensure that dangerous accumulations of gas are avoided or dealt with promptly.

Protection of hazardous areas from explosions has been a concern since the industrial revolution. Passive methods, which emphasize preventing an ignition source from reaching the gas, have been used historically-the supposition being that a flammable mixture of gas is present. The lower flammability limit (LFL) is the minimum concentration of a flammable gas in air that will support combustion. Typically 1 to 10 percent of such a gas in air is flammable. Table 1-1 gives values of the LFL in terms of the volume percent of gas in air for a selection of flammable gases. There is also an upper flammability limit (UFL) because if insufficient oxygen is present in a gas mixture, then combustion cannot be supported.

Table 1-1. Minimum Volume Percent of Gas in Air Capable of Supporting Combustion (Lower Flammability Limit).

\begin{tabular}{|l|c|}
\hline \multicolumn{1}{|c|}{ Gas } & Mintmerm volume percent \\
\hline Hydrogen & 4.0 \\
\hline Ammonia & 15.0 \\
\hline Methane & 5.0 \\
\hline Acetylene & 2.5 \\
\hline Butane & 1.9 \\
\hline Naphthalene & 0.9 \\
\hline Carbon monoxide & 12.5 \\
\hline
\end{tabular}

Radioactive liquid waste tends to produce hydrogen as a result of the interaction of $\gamma$-radiation and water. If the waste contains organic chelating agents, additional hydrogen gas, as well as nitrous oxide and ammonia, can be produced by thermal and radiolytic decomposition of these organics. Several high-level radioactive liquid waste storage tanks, located underground at the Hanford Site in Washington State, contain waste that retains the gases being produced in them until large amounts are suddenly released to the tank vapor space. Tanks nearly filled to capacity have relatively little vapor space; therefore, if the stored waste rapidly releases hydrogen and nitrous oxide, a flammable gas moisture may result. The most notable example of a Hanford waste tank with a flammable gas problem is 
tank 241-SY-101. Waste stored in this tank has released upon occasion enough flammable gas to burn if an ignition source had been present inside of the tank. Several other Hanford waste tanks exhibit similar behavior although to a lesser magnitude.

Ignition of a flammable gas mixture in a waste tank could lead to a release of radionuclides to the atmosphere through risers in the tank dome.* At sufficiently high concentrations of flammable gases, the mixture will detonate. The resulting explosion could cause permanent damage to the tank as well as emission of radioactive effluents. A severe explosion might preclude further containment of the waste.

Although the tendency of Hanford high-level radioactive liquid waste to generate and retain flammable gas was recognized as a serious problem by 1979 , this problem did not receive adequate attention. Combustion of flammable gas mixtures containing the oxidizer nitrous oxide was not considered in the Safety Analysis Report of worst-case accidents. An investigation of this phenomena in 1990 resulted in a Flammable Gas Watch List for 25 Hanford waste tanks and an unreviewed safety question (USQ).*** The condition of these tanks was declared an unreviewed safety question because of the potential radiological consequences from a waste release following ignition of an accumulated mixture of nitrous oxide and hydrogen, an event that had not been analyzed in any previous safety analysis.

Actions taken under the U.S. Department of Energy (DOE) Order 5480.5, Safety of Nuclear Facilities (DOE 1986), for a USQ will normally culminate in an updated safety analysis report and new operating restrictions. Interim operating restrictions have been implemented through Interim Operational Safety Requirements to reduce ignition sources and the potential for sparks. As a result, the following activities are restricted for Flammable Gas Watch List tanks:

- Waste transfers into and out of tanks

- Waste core sampling

- In-tank photography

* Risers provide a path from the tank dome to ground level so that instruments can be inserted into the tank.

*winitially, corporate reports and letters were reviewed to find taaks that exhibited slurry growth, a possible manifestation of gas retention in liquid. This resulted in 5 double-shell tanks and 15 single-shell tanks being placed on the Flammable Gas Watch List. Subsequent criteria resulted in the addition of 2 more single-shell tanks, for a total of 22 tanks. Because the vapor spaces of 5 Watch List tanks are vented through tank 241-SX-109, it was also added to the Watch List. The waste surface level in tank 241-AW-101 increased and later decreased, with pressure spikes accompanying both these changes. As a result, tank 241-AW-101 was added to the Watch List. Finally, an organic Watch List tank, 241-U-107, was recently added to the Flammable Gas Watch List because it also exhibited slurry growth. A new method is being developed for determining which tanks should be included on this list. 
- Work in the primary tank dome space or on associated ventilation/exhaust systems

- Work in the tank annulus or on associated annulus peripheral equipment

- Work in the vicinity of the tank or exhaust systems

Additional requirements were imposed on the following activities:

- Hydrogen/flammable gas monitoring

- Increased supervision

- Management approval of waivers for any of the special requirements or restrictions

Also, on November 5, 1990, the United States Congress passed Public Law 101-510, Section 3137, "Safety Measures for Waste Tanks at Hanford Nuclear Reservation," which addresses safety issues concerning the handling of high-level nuclear waste. This law which directs the Secretary of the DOE to take the following actions:

- Identify those tanks that "...may have a serious potential for release of highlevel waste due to uncontrolled increases in temperature or pressure..."

- Ensure that "...continuous monitoring to detect a release or excessive temperature or pressure..." is being carried out

- "...develop action plans to respond to excessive temperature or pressure or a release from any tank identified..."

- Restrict additions of high-level nuclear wastes to the identified tanks unless no safer alternative exists, or the serious potential for a release of high-level nuclear waste is no longer a threat.

This law also directs the DOE Secretary to report to Congress "... on actions taken to promote tank safety, including actions specifically taken pursuant to this section of the law, and the Secretary's timetable for resolving the outstanding issues on how to handle the waste in such tanks." 
This page intentionally left blank. 


\subsection{THE SAFETY ISSUE}

The Hanford high-level radioactive liquid waste storage tanks on the Flammable Gas Watch List are shown in Table 2-1.

Table 2-1. Flammable Gas Watch List Tanks.

\begin{tabular}{|c|c|c|}
\hline \multicolumn{2}{|c|}{ Single-shell tanks } & Double-shell tanks \\
\hline $101-\mathrm{A}$ & $105-\mathrm{SX}$ & $103-\mathrm{AN}$ \\
\hline $101-\mathrm{AX}$ & $106-\mathrm{SX}$ & $104-\mathrm{AN}$ \\
\hline $103-\mathrm{AX}$ & $109-\mathrm{SX}$ & $105-\mathrm{AN}$ \\
\hline $102-\mathrm{S}$ & $110-\mathrm{T}$ & $101-\mathrm{SY}$ \\
\hline $111-\mathrm{S}$ & $103-\mathrm{U}$ & $103-\mathrm{SY}$ \\
\hline $112-\mathrm{S}$ & $105-\mathrm{U}$ & $101-\mathrm{AW}$ \\
\hline $101-\mathrm{SX}$ & $107-\mathrm{U}$ & \\
\hline $102-\mathrm{SX}$ & $108-\mathrm{U}$ & \\
\hline $103-\mathrm{SX}$ & $109-\mathrm{U}$ & \\
\hline $104-\mathrm{SX}$ & & \\
\hline
\end{tabular}

The waste stored in these tanks tends to be viscous with non-uniform temperatures and fluctuating surface levels. Temperature profiles and surface levels can be correlated with gas retention and release. Double-shell tank 241-SY-101 retains so much of the gas generated in its waste that, when the gas is released, violent waves are produced and flammable gas mixtures are occasionally measured. When the gas is released, the waste surface level can drop about one-foot. This type of behavior must be prevented or mitigated.

Tanks 241-AW-101, 241-SY-103, 241-AN-103, 241-AN-104, and 241-AN-105 give clear indications of similar behavior but to a much lesser degree.* Single-shell tanks however, do not have the same problem. They were added to the Flammable Gas Watch List because at some past time the waste stored in them exhibited a phenomenon called slurry growth. Slurry growth is a gradual increase in waste volume associated with the generation and retention of gas in the waste, the generation of a low-density condensed phase (e.g., foam), or both. The current approach for single-shell tanks is to install equipment for monitoring the gases in the tank dome spaces and take additional actions, if necessary.

*For example, tank 241-AW-101 contains about 4,001,168 liters (1,057,000 gallons) of slurry and 317,974 liters (84,000 gallons) of sludge for a waste surface level of about $1041 \mathrm{~cm}$ ( $410 \mathrm{in}$.). Surface level drops of from 1 to $5 \mathrm{~cm}(0.5$ to $2 \mathrm{in}$.) are similar to those that occur in the other double-shell tanks. 
The safety issue for the Flammable Gas Watch List tanks is evident in the following:

- The potential for igniting flammable gases such as hydrogen-air and/or hydrogen-nitrous oxide which could result in a release of radioactive material.

- The potential for releasing waste material due to a large pressure pulse during a gas release event.

Figure 2-1 illustrates the conditions in which a release can occur.

Figure 2-1. Mechanisms for Releasing Material from a Flammable Gas Watch List Tank.

FACTORS THAT CAUSE A RELEASE TO THE ENVRONMENT, AND ROUTESMETHODS OF RELEASE

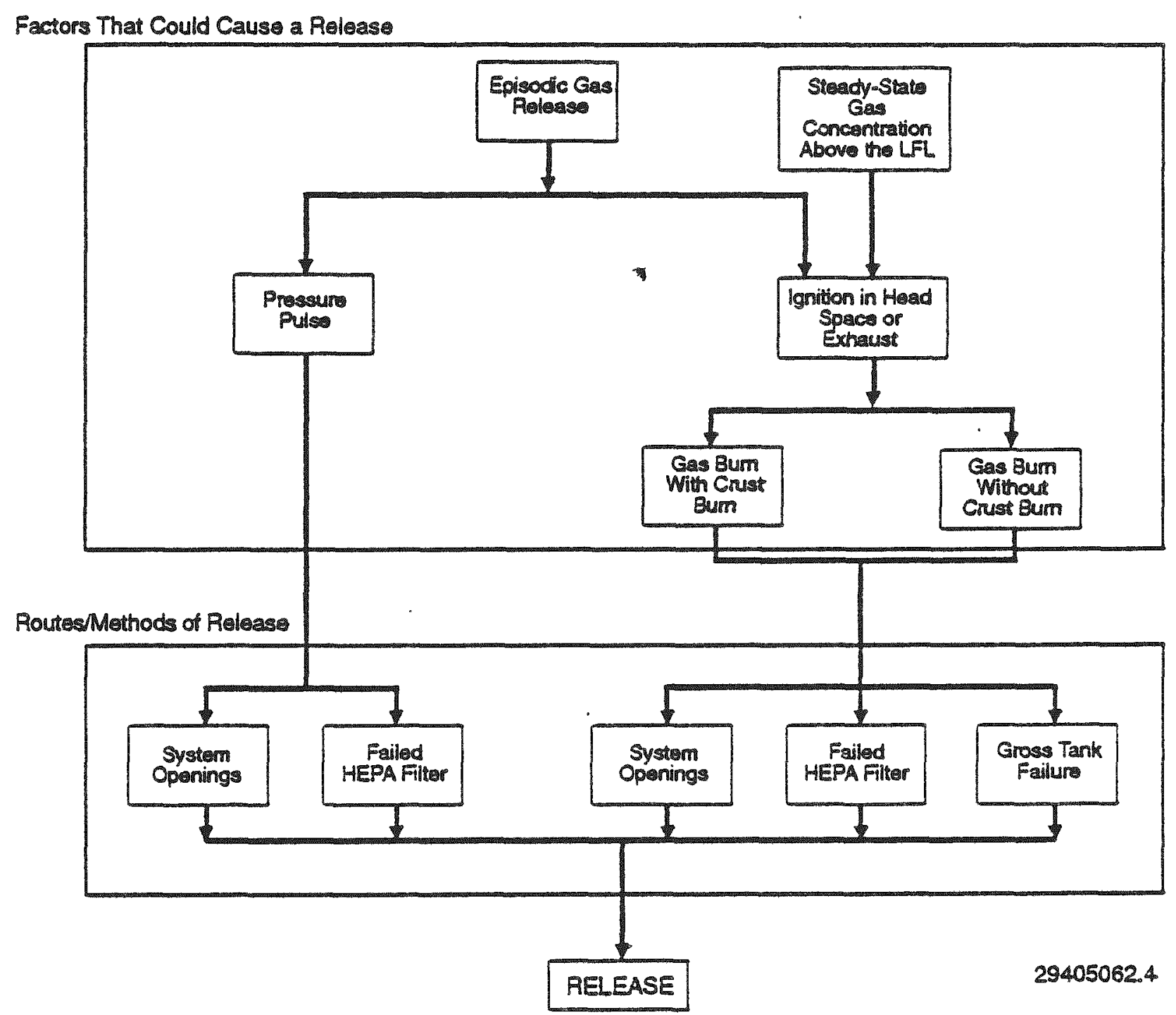


The major objective of this program is to develop and implement methods for controlling the retention and periodic release of flammable gases so that Hanford high-level radioactive waste tanks are maintained in as stable a condition as possible. Two additional objectives are to ensure that Tank Farm operations do not lead to conditions that could create an accident and to upgrade the monitoring instrumentation on the tanks. 
WHC-SD-WM-SD-019 Rev。0

This page intentionally left blank. 


\subsection{FLAMMABLE GAS TANK SAFETY ISSUE RESOLUTION}

An approach to resolve the flammable gas safety issue is shown in Figure 3-1. After evaluating the problem, one or more options can be selected to resolve the safety issue:

$\begin{array}{ll}\text { - } & \text { Mero option" } \\ \text { - } & \text { Mitigation } \\ \text { - Resolution. }\end{array}$

The options lead to removing one or more tanks from the Flammable Gas Watch List by controlling or eliminating the hazard. The option selected depends on the type of behavior exhibited by the tank(s). Important terms are defined as follows:

- Mitigation: Actions which prevent the episodic release of flammable gases.

- Zero Option: In-situ safe storage of waste without further treatment. Review of historical records and modification of administrative controls will always be a part of this option.

- Pretreatment: The process used to prepare waste for treatment.

- Disposal: Actions to isolate waste from the biosphere for the foreseeable future, with no intent of retrieval. Deliberate action is required to regain access to the waste.

- Remediation: Actions to safely store, maintain, treat, and dispose of tank waste forms.

The paragraphs below provide the details of the logic for resolution of the flammable gas issue. Figures 3-2 through 3-10 provide details for the options given in Figure 3-1.

\subsection{EVALUATING THE PROBLEM}

The process of evaluating the flammable gas tank safety issue is illustrated in Figure 3-2.

Work priorities are developed from a review of historical data, synthetic waste studies, laboratory tests, analytical modeling, and sensitivity analyses (see Figure 3-3, 1.1.1 and 1.1.2), when direct information about the behavior of tank waste is unavailable. Data from actual waste samples and tank monitoring will be obtained as equipment is developed or otherwise becomes available (for example, temperature, pressure, waste surface level). 


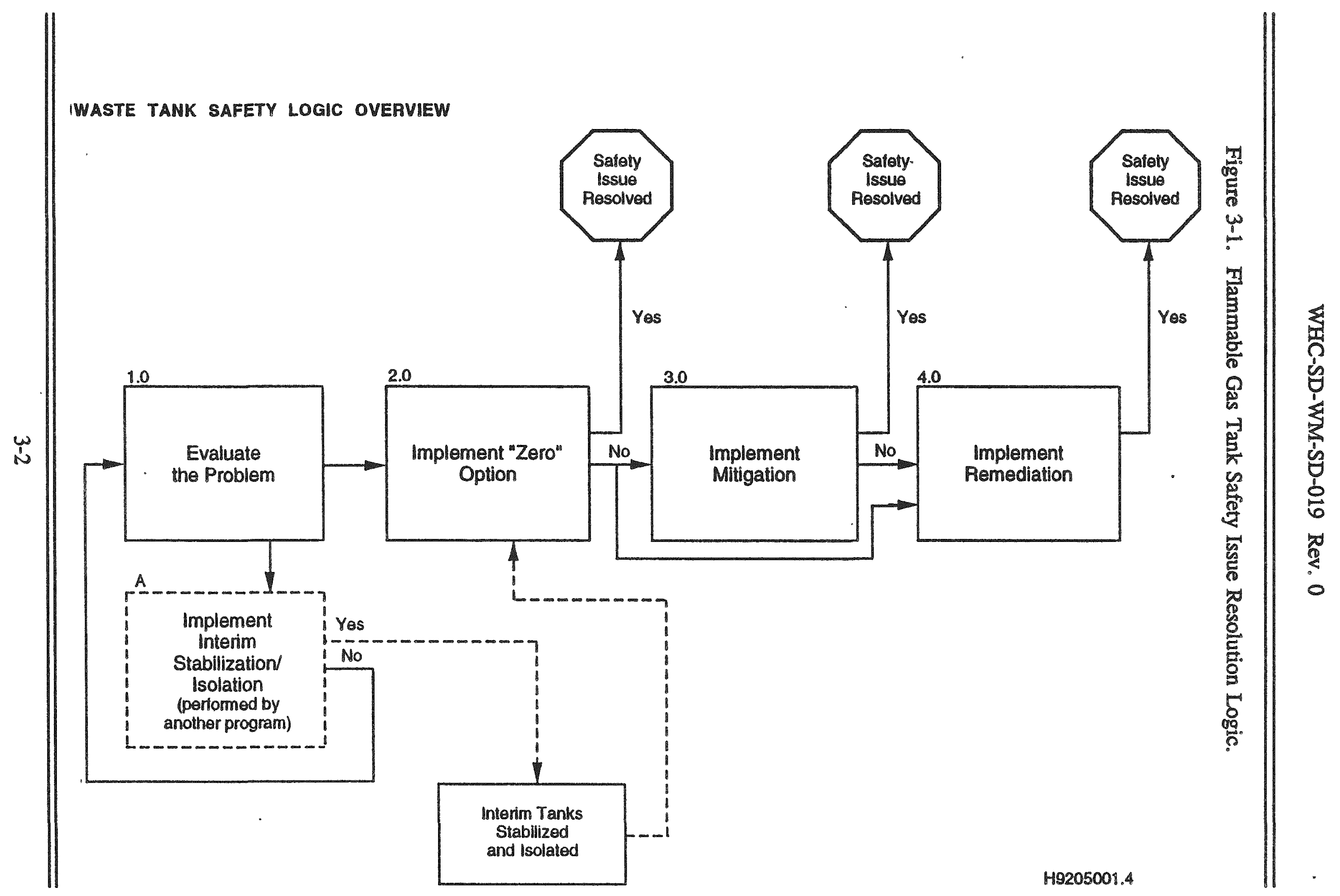


LOGIC FOR WASTE TANK SAFETY ISSUE

RESOLUTION IN NETWORK FORMAT

(BY TANK OR GROUPS OF TANKS)

1.0 EVALUATE AND DEFINE THE PROBLEM

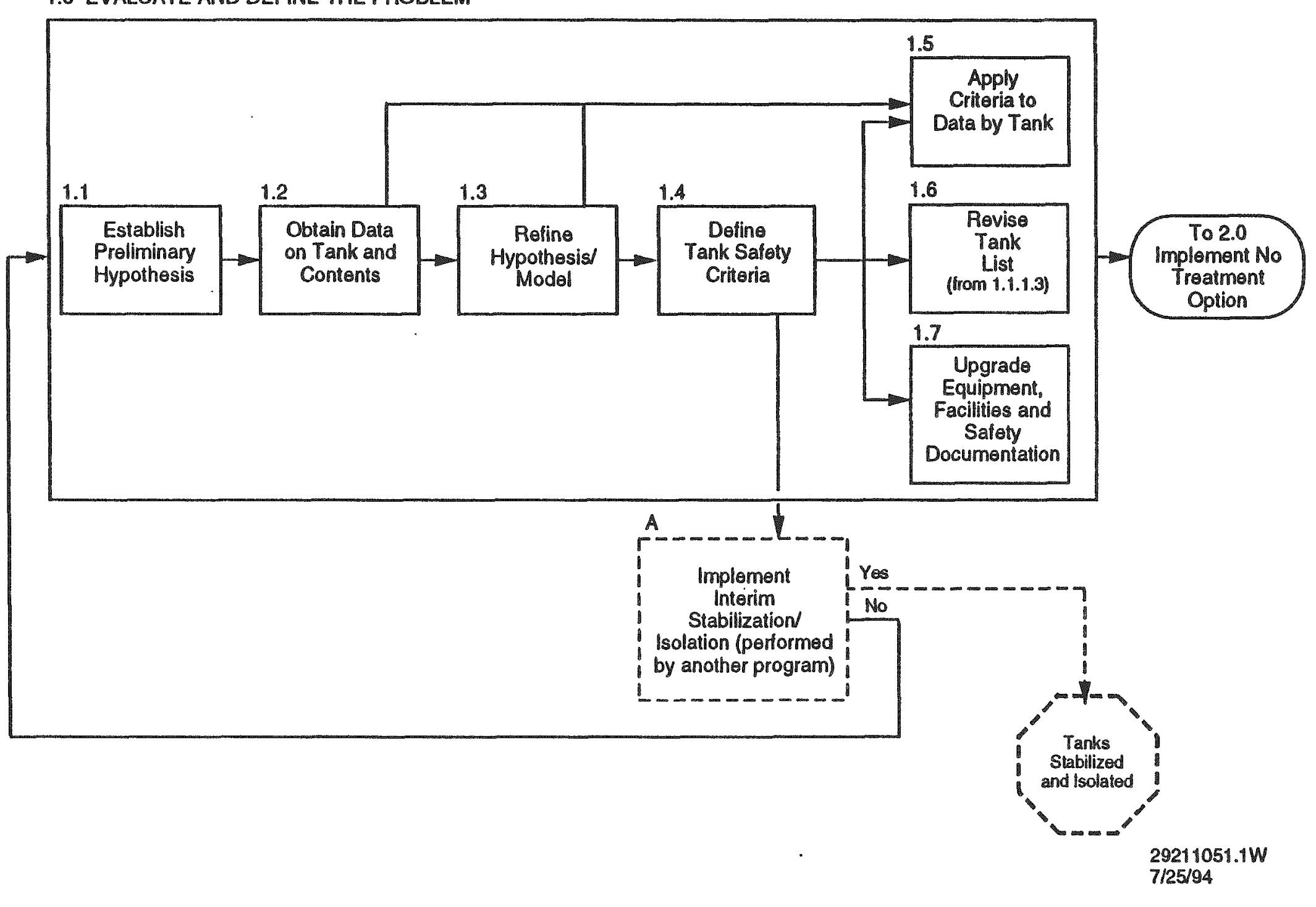


LOCIC FOP WASTE TANK SAFETY ISSUE RESOLUTION

WN NETWORK FORMAT

(BY TANK OR GROUPS OF TANKS)

\subsection{EVALUATE THE PROBLEM}

1.1 Establish Proliminary Hypothosis

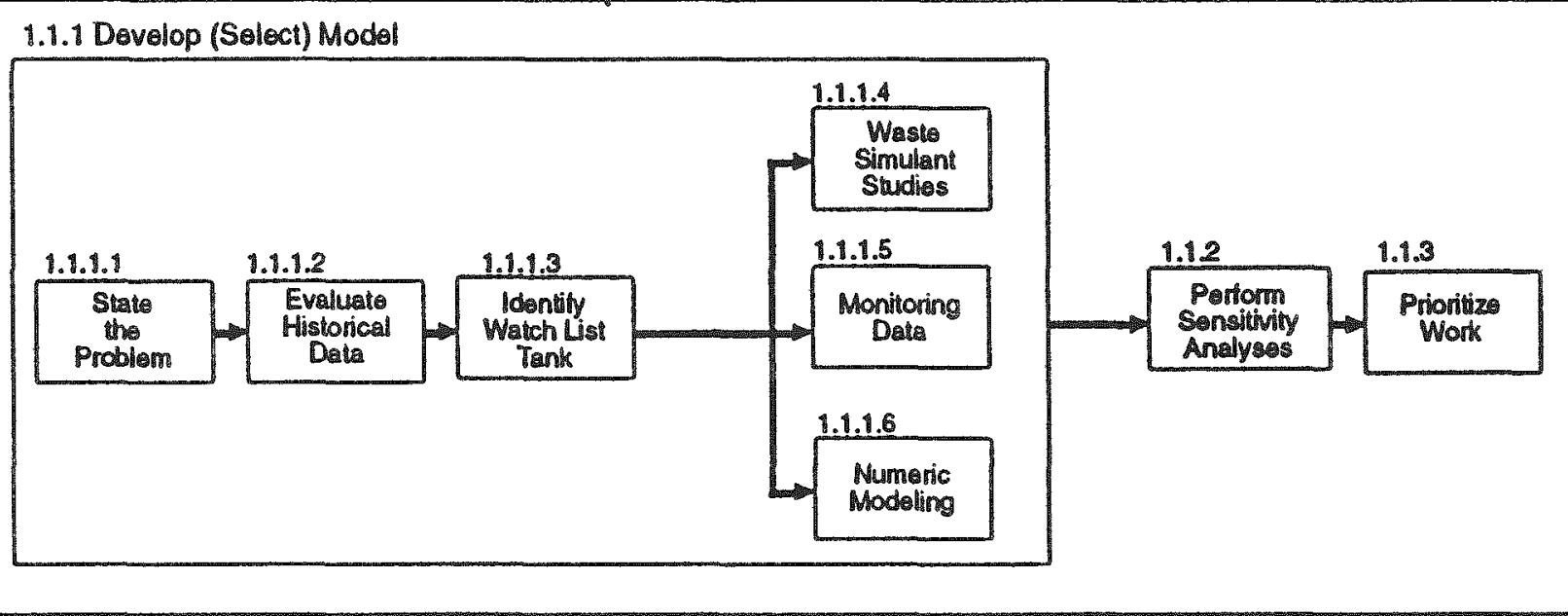

1.2 Obtain Data on Tank anid Contents

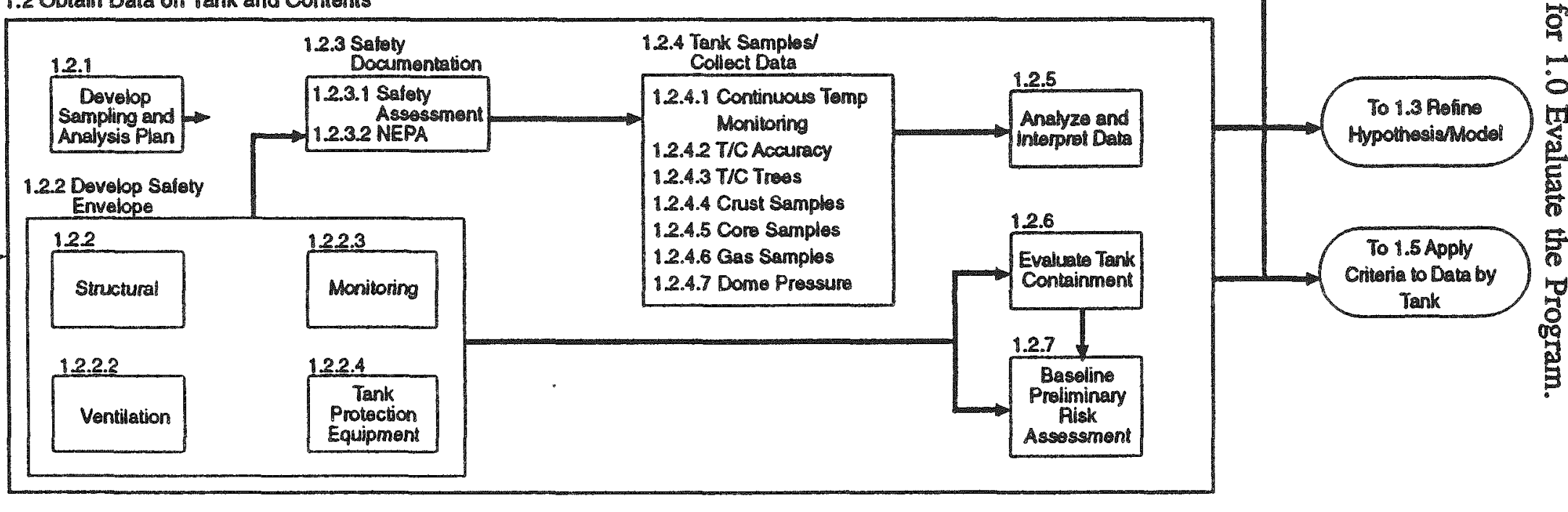


Results from sampling each waste tank could validate a preliminary hypothesis about the behavior of waste in a tank, but additional studies and sampling may be required before a quantitative understanding or model of waste behavior is developed.

A model for the behavior of Flammable Gas Watch List tanks may be used to improve criteria for operating the tanks (see Figure 3-4) and to determine whether it is safe to stabilize and isolate single-shell tanks that have not already been stabilized and isolated. Other applications for this information are as follows (see Figure 3-5).

- Task 1.5 - Apply Criteria to Data by Tank. This task will redefine the safety envelope based on technical evaluations, hazards reassessment, and probable risk assessment.

- Task 1.6 - Revise Tank List. This task will revise the list of tanks with safety issues requiring resolution. Tanks will be added or removed based on documentation approved by the appropriate authority.

- Task 1.7 - Upgrade Equipment, Facilities and Safety Documentation. This - task will upgrade gas monitors, instrumentation, and ventilation. It will also redefine the safety envelope and determine control limits.

After evaluating tank behavior decisions can be made on the appropriate option to resolve the safety issue.

\subsection{IMPLEMENTING THE ZERO OPTION}

The zero option (see Figure 3-6) involves minimal risk tanks. The appropriate disposition for each tank will be based on redefining the safety envelope, revising the Flammable Gas Watch List, and establishing work controls. Possible dispositions include the following:

- Remove tanks from the Watch List and take no further action because they are inherently or passively safe.

- Remove tanks from the Watch List after completing upgrades, redefining the safety envelope, and determining work controls consistent with zero option safety criteria developed in Task 1.4 (see Figure 3-4).

- Determine that the zero option is not viable in which case mitigation or remediation will be required to resolve the safety issue.

Most tanks will be dispositioned in this manner. 
LOGIC FOR WASTE TANK SAFETY ISSUE RESOLUTION IN NETWORK FORMAT

(BY TANK OR GROUPS OF TANKS)

1.0 EVALUATE THE PROBLEM (CONTINUED)

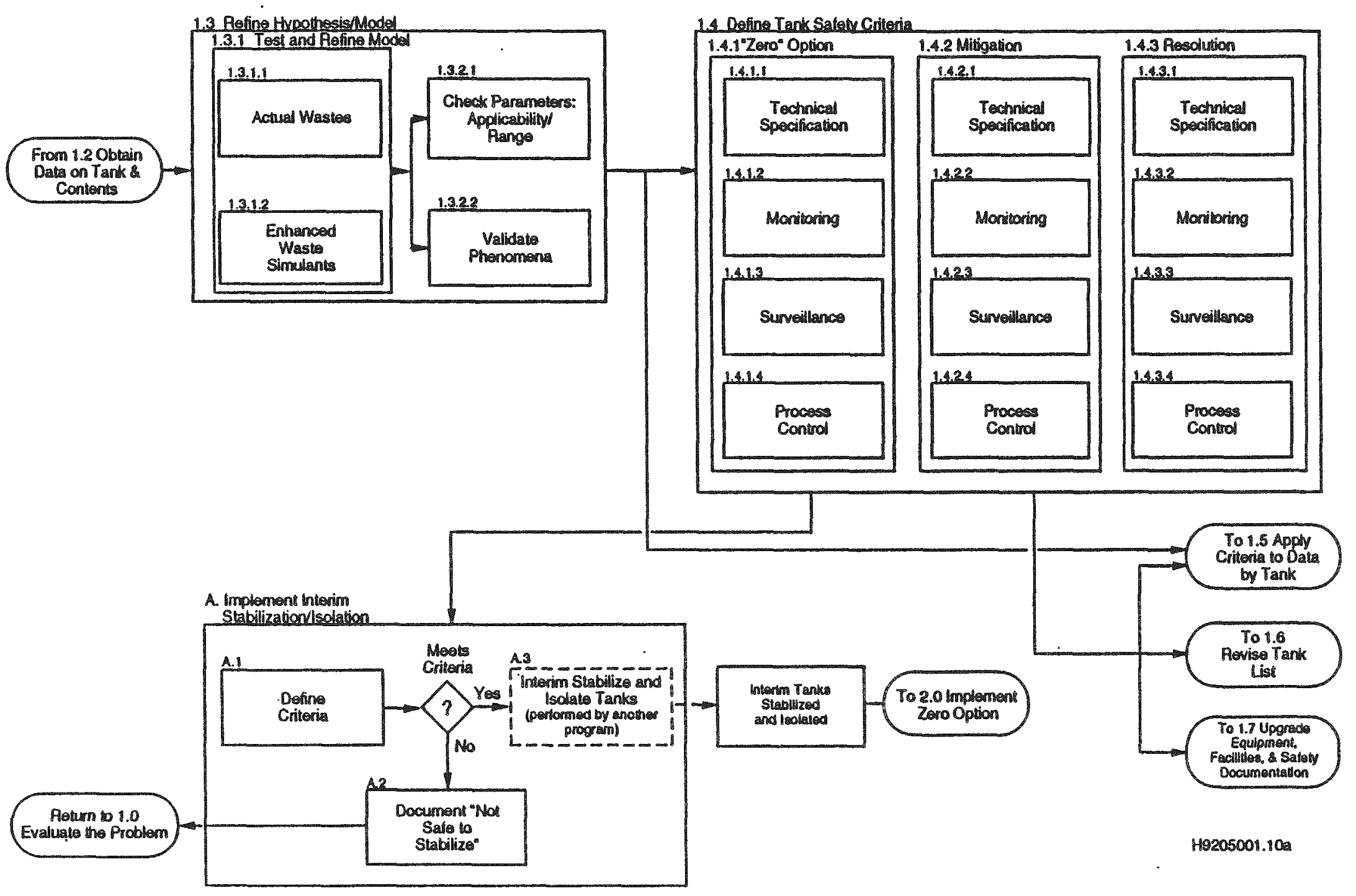


LOGIC FOR WASTE TANK SAFETY ISSUE RESOLUTION

IN NETWORK FORMAT

(BY TANK OR GROUPS OF TANKS)

1.0 EVALUATE THE PROBLEM (CONTINUED)

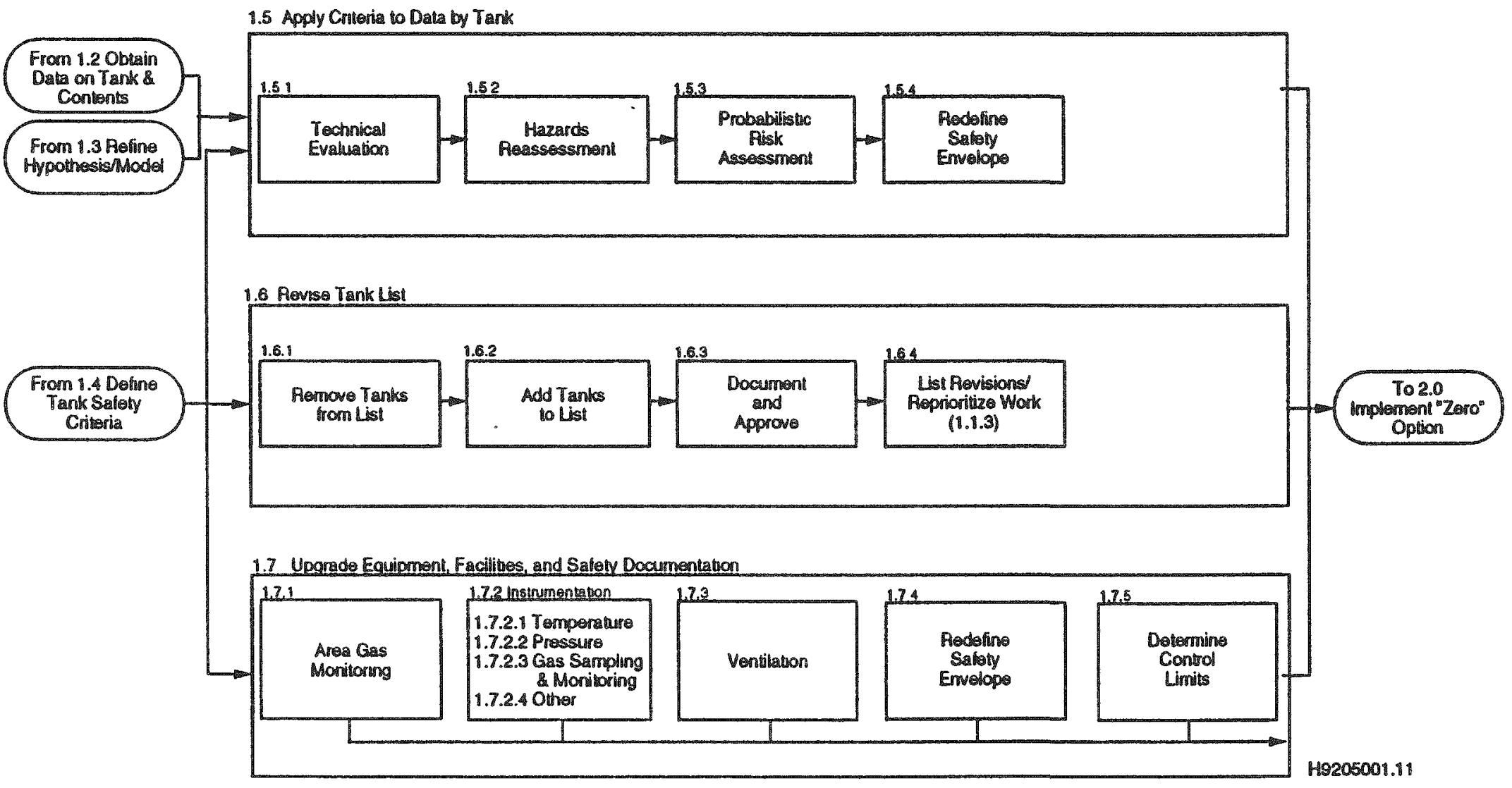

1.7 Uporade Equipment, Facilines, and Salemy Documentanon

\begin{tabular}{|c|c|c|c|c|}
\hline 1,21 & 1.72 ingtrumentation & & 124 & \\
\hline $\begin{array}{l}\text { Arsa Cos } \\
\text { Monitorng }\end{array}$ & \begin{tabular}{|l|} 
1.7.2.1 Tomperaure \\
1.7.2.2 Pressure \\
1.7.2.3 Gas Sampling \\
\& Monitoring \\
1.7.2.4 Other
\end{tabular} & Ventilauon & $\begin{array}{l}\text { Pedofine } \\
\text { Salioty } \\
\text { Emvelope }\end{array}$ & $\begin{array}{l}\text { Determine } \\
\text { Control } \\
\text { Limits }\end{array}$ \\
\hline
\end{tabular}




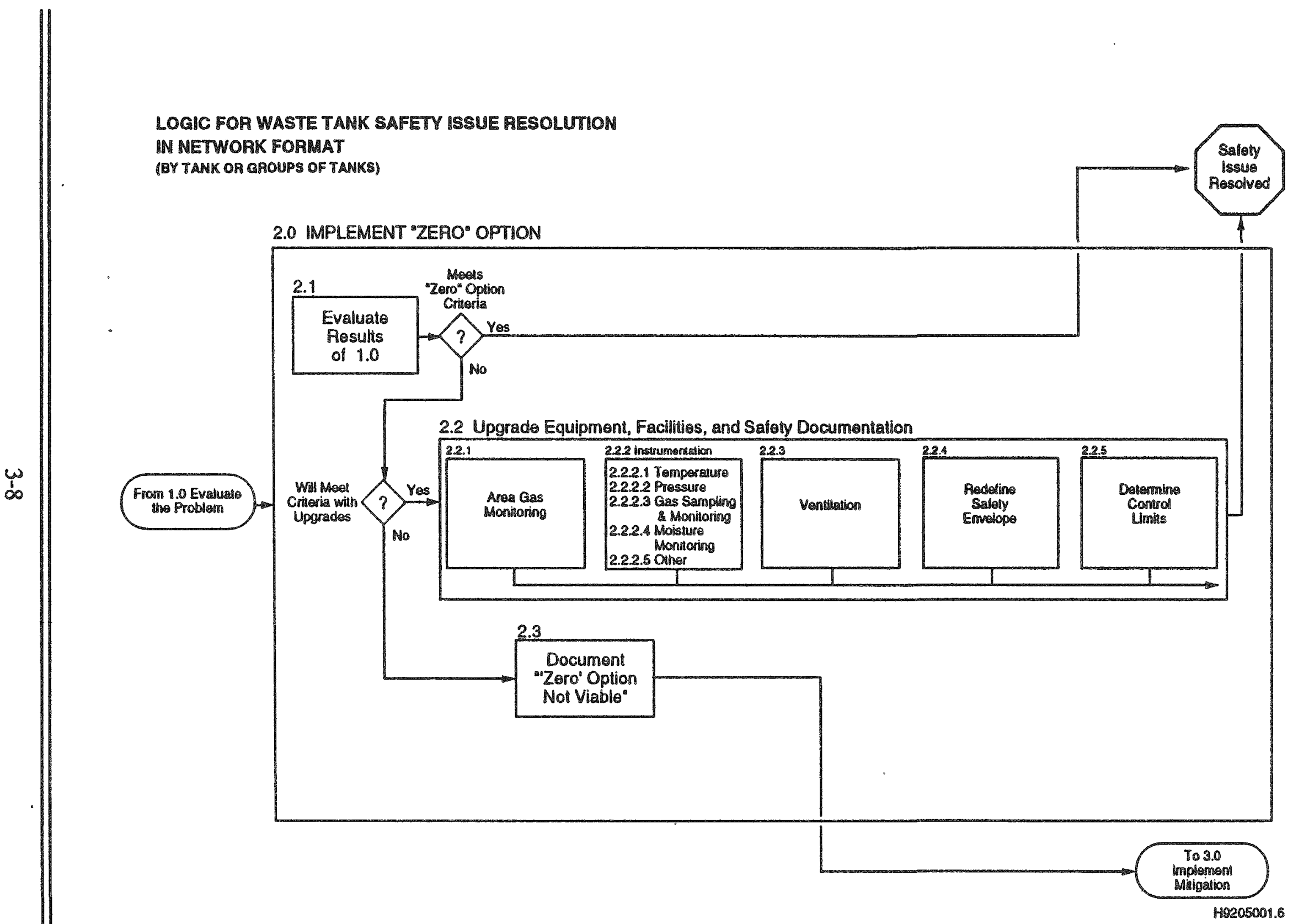




\subsection{IMPLEMENTING MUTIGATION}

Events leading to a hazardous situation occur in sequence. If these events or combinations of events can be eliminated, the consequences of the hazard will be eliminated or reduced to an acceptable level. The mitigation option (Figure 3-7) applies to tanks where a hazard can be controlled or eliminated by in-tank treatment, for example, operation of a mixer pump in tank 241-SY-101. The first step taken to resolve the safety issue is therefore to identify events (see Figures 3-7 and 3-8) leading to an undesirable situation. Sometimes postulated events can be evaluated in the laboratory; otherwise engineering judgment and analysis is the only evaluation tool.

In the unlikely event that tanks other than 241-SY-101 require mitigation, several approaches may be examined. The most important criteria for selecting a particular approach relate to the effects that it might have upon the final treatment of the waste, the rapidity with which it could be implemented, its potential for success and cost.

Implementing a mitigation approach (see Figure 3-8) begins with a scaled proof of concept to validate laboratory scale testing. An important part of this evaluation deals with the impact of the approach on the integrity of the tank and on the final disposal of its waste. Once a scaled proof of concept is demonstrated, design and fabrication can begin. Safety and environmental documentation will be prepared at the same time, and permission to operate in the affected tanks will be secured. When these tasks have been completed, the mitigation approach can be implemented.

After the selected option has been implemented, tank sampling or data monitoring will indicate whether the tank is actually mitigated or not. If so, then the safety issue is resolved. The tank can be removed from the Flammable Gas Watch List and managed as a tank with no safety issue. If mitigation is not sufficient to resolve the safety issue, then further resolution steps will be required.

\subsection{IMPLEMENTING THE RESOLUTION}

The resolution path (see Figure 3-9) applies to tanks where the hazard cannot be controlled or eliminated by in-tank treatment of waste. To resolve the safety issue, the waste must be removed from the tank and transferred to another location for treatment and storage. Except for the last step, the logic steps for implementing resolution in Figures 3-9 and 3-10 are identical to the steps for implementing mitigation (see Figures 3-7 and 3-8) step. 
LOGIC FOR WASTE TANK SAFETY ISSUE

RESOLUTION IN NETWORK FORMAT

(BY TANK OR GROUPS OF TAMKS)

3.0 IMPLEMENT MITIGATION

$$
3.1
$$

3.3

Identify
Pathway to

.2

Evaluato

Hazard

Approarmine

Proempt Path

Aporoaches

by Criteria
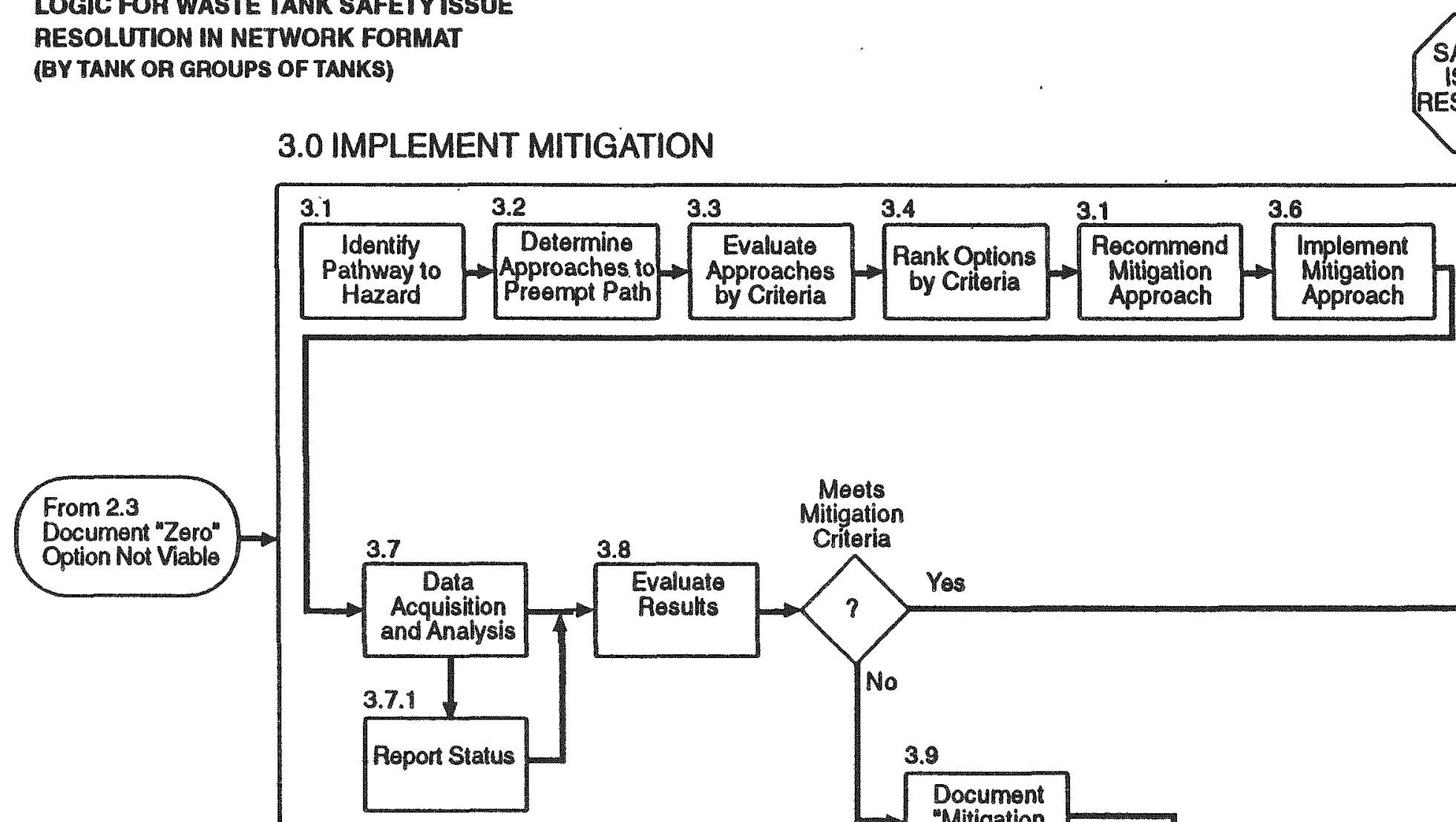

Meots

Criteria

Yos

No

To 4.0

Implement

Resolution

29405062.1 
LOGIC FOR WASTE TANK SAFETY ISSUE RESOLUTION

IN NETWOAK FORMAT

(BY TANK OR GROUPS OF TANKS)

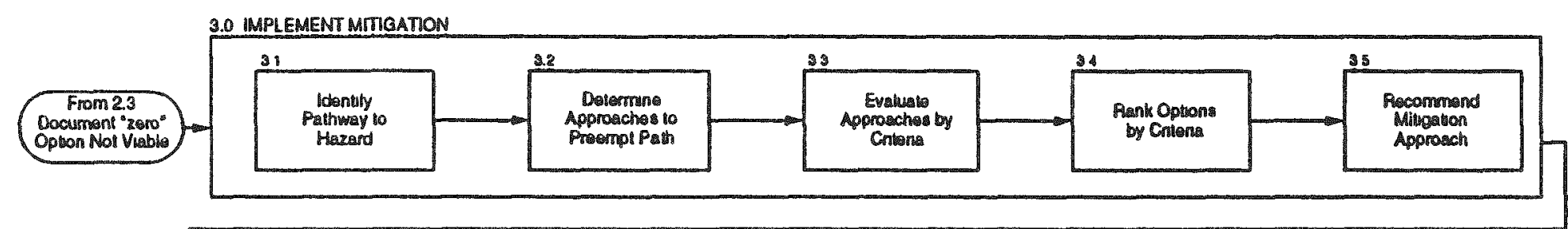

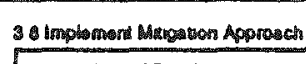

20.1 scand Proo

$$
\begin{aligned}
& 2011 \\
& \text { Ethecess }
\end{aligned}
$$

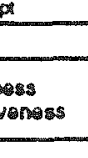

0.012

$\stackrel{\omega}{\rightleftarrows}$
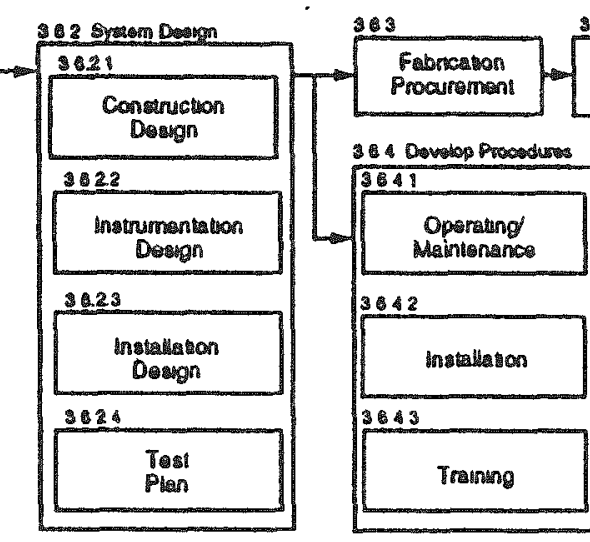

2013

Assams impacion
Tank Integny

3014

Aralyze Scaling

3015

Asanss impact on
Funal Dusposal

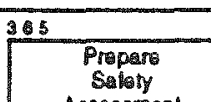

Assasment

906 Propare

Assessinent

39

Modidyl
Enhance

Contannent 
LOGIC FOP WASTE TANK SAFETY ISSUE RESOLUTION

IN NETWORK FORMAT

(BY TANK OR GROUPS OF TANKS)

\subsection{IMPLEMENT RESOLUTION}

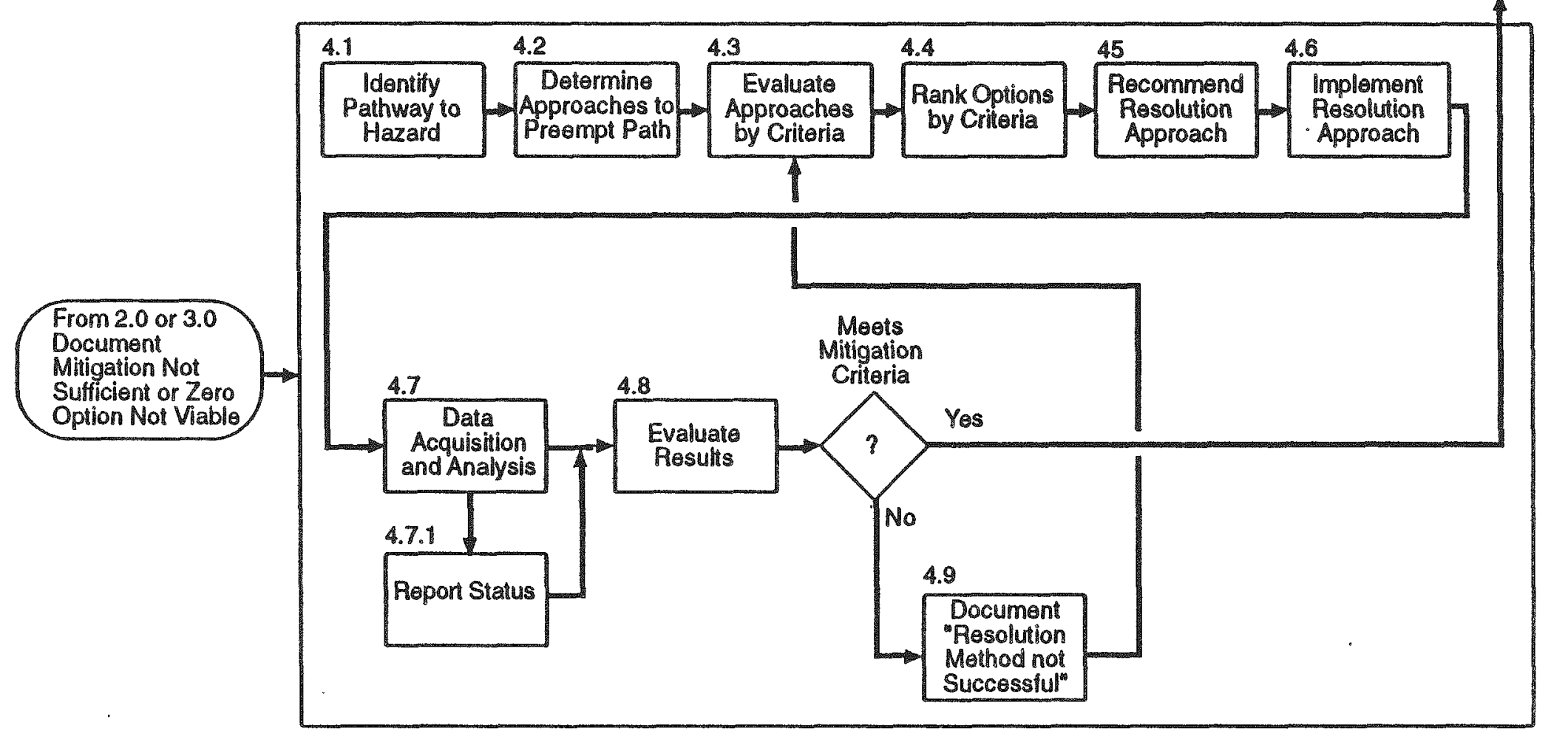


LOGIC FOR WASTE TANK SAFETY ISSUE RESOLUTION

W NETWORK FORMAT

(BY TANK OR GROUPS OF TANKS)
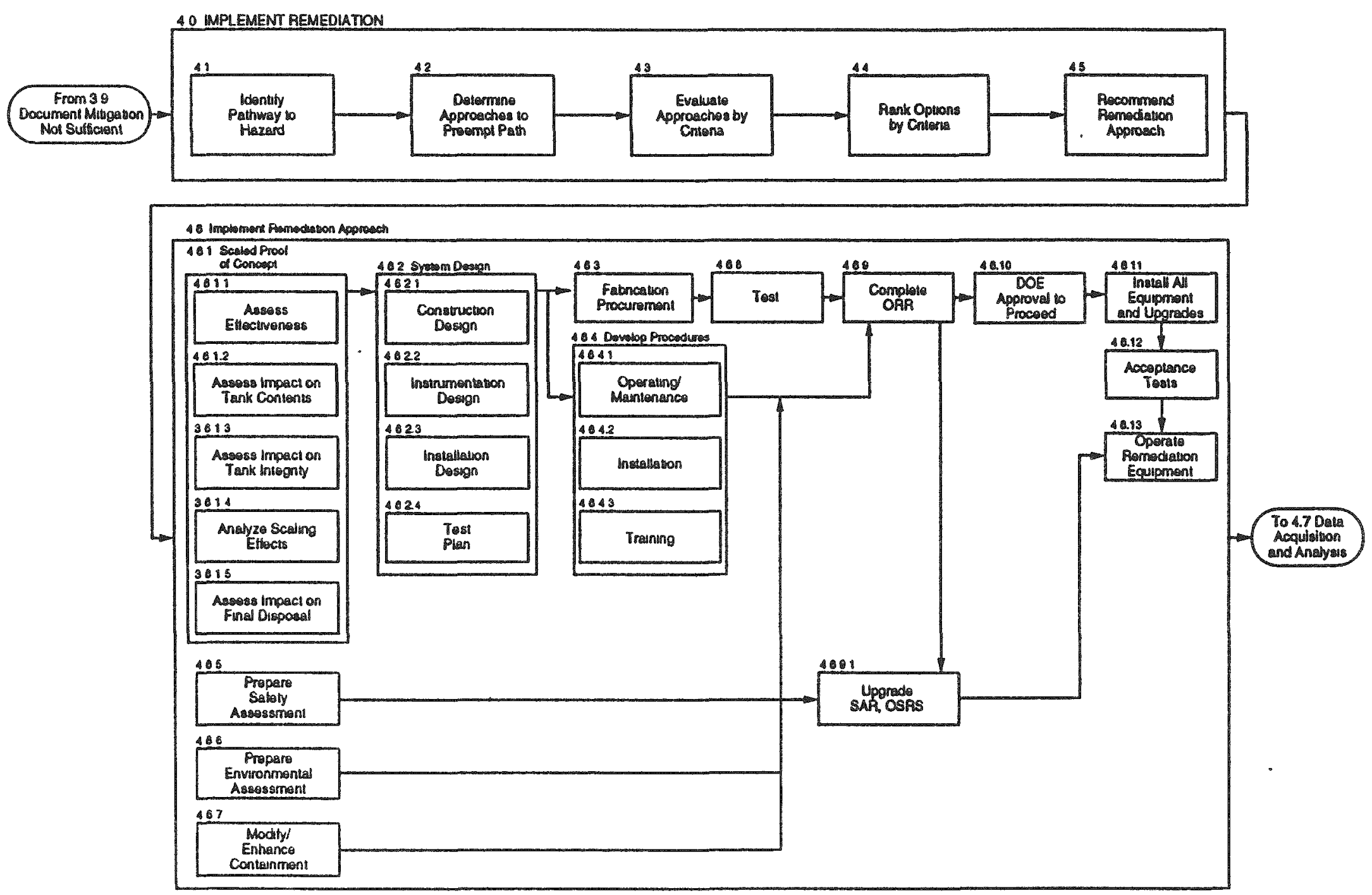
This page intentionally left blank. 


\subsection{PROGRAM ACTIVITIES}

The process by which safety issues are to be resolved includes evaluating the problem, then selecting one or more of the following options as appropriate:

- Storing the waste without further treatment (zero option)

- Taking action within designated tanks to treat waste and reduce the severity of the safety issue (mitigation option)

- Taking action outside of designated tanks to store, maintain, treat, and dispose of waste.

Resolving the safety issue for a tank is progressively more difficult and costly as the number of options required increase. It is expected that the safety issue for most of the 25 Flammable Gas Watch List tanks will be resolved by the first or second option shown above. For the remaining Watch List tanks, resolution will be accomplished by in-tank treatment of the waste or by removing the waste for storage in another tank with or without treatment.

Program activities for the Flammable Gas Tank Safety and the Hydrogen Mitigation Programs have been grouped into the five categories listed below. The categories are discussed in detail in the sections that follow.

- Characterization and evaluation

- Technology

- Safety documentation and unreviewed safety question resolution

- Equipment and instrumentation upgrade

- Mitigation.

\section{Characterization and Evaluation}

Data must be obtained to enhance our understanding of the causes of gas retention by highlevel radioactive liquid waste. This includes historical information, waste characterization data, and evaluation of gases in the tank dome spaces. Detailed evaluations of this information will be used to interpret the behavior of waste in the Flammable Gas Watch List tanks. 


\section{Technology}

The technologies used will include the following:

- Laboratory studies using synthetic waste to determine the chemical and physical mechanisms of gas generation and retention in Watch List tanks

- Development of tank models to simulate gas release phenomenon and evaluate strategies for mitigation of flammable gas releases

- Development of analytical techniques to characterize chelators and chelator fragments in tank waste

- Development of waste sampling techniques.

\section{Safety Documentation and Unreviewed Safety Question Resolution}

Safety analyses are required for tank-intrusive activities, such as sampling and instrumentation upgrades. Reports will be prepared to document how tanks are removed from the Watch List. The primary focus of this activity is closure of the unreviewed safety question. The work scope includes the following:

- Preparing hazard assessments and probabilistic risk assessments

- Defining tank safety criteria

- Redefining tank safety envelopes

- Compiling documents that support the Interim Safety Basis

- Recommending resolution/closure of the unreviewed safety question for the various tanks.

\section{Equipment and Instrumentation Upgrades}

The following upgrades will be funded: the multi-functional instrument tree, the temperature monitoring and control system, gas monitoring cabinets, surface-level detectors, closedcircuit TV cameras, modular exhausters, inlet filters, data acquisition and control systems, and removal and disposal of any damaged, inoperable, or interfering equipment from the waste tanks. 


\section{Mitigation}

The primary focus is to develop and implement a method to reduce the severity of the hazard posed by episodic releases of flammable gas mixtures in tank 241-SY-101. An ongoing program to mitigate gas release events in this tank has been successful to date. Four options are being evaluated: mixing, dilution, heating, and sonic agitation.

\subsection{CHARACTERIZATION AND EVALUATION}

To resolve the safety issues, it is necessary to understand the chemical and physical properties of waste material in the Flammable Gas Watch List tanks. This can be accomplished by retrieving* and analyzing waste samples from the tank in question. Data requirements for safety analyses, mitigation actions, and modeling activities are described in Table 4-1.

\subsubsection{Waste Sampling}

Samples of the liquid and slurry layers beneath the crust must be collected and analyzed to understand the mechanisms by which hydrogen and other gases are generated, stored, and periodically released from the waste. A detailed analytical chemistry plan has been prepared for core samples taken from tank 241-SY-101. Table 4-2 summarizes the analyses conducted on waste samples. The majority of these analyses will be performed by the Westinghouse Hanford Company. Support will be provided by the Pacific Northwest Laboratory for the following types of characterization: organic compound analyses, radionuclide analyses, gas phase analysis, and characterization of physical properties. The organic characterization will include analyses for volatile and semivolatile organics as well as chelators and their degradation products. The analyses for volatile and semivolatile compounds will be performed by gas chromatography/mass spectrometry. Analytical methods for the chelators are not yet in place (see Section 4.2.3). The gas phase analysis will determine nonhydrocarbon gases and hydrocarbons. The analyses for the nonhydrocarbon gases and light hydrocarbons will be performed by quantitative mass spectrometry.

*Methods for retrieving waste samples include auger sampling, core drilling, and removal of crust material adhering to existing instruments and other equipment taken from the tanks. 
Table 4-1. Data Requirements. (2 sheets)

\begin{tabular}{|c|c|}
\hline Requtirements & Description \\
\hline \multirow[t]{3}{*}{ Modeling } & $\begin{array}{l}\text { Evaluate crust characteristics and composition supporting the evaluation of } \\
\text { gas release mechanisms. Crust characteristics include the following: } \\
\text { Composition (anions, cations, organics, radionuclides) } \\
\text { Density } \\
\text { Percent water } \\
\text { Differential scanning calorimetry (performed from ambient to } 450^{\circ} \mathrm{C} \text { ) } \\
\text { Thermal conductivity } \\
\text { Porosity" (i.e., permeability) }\end{array}$ \\
\hline & $\begin{array}{l}\text { Evaluate liquid layer thermal and rheological properties supporting the } \\
\text { development of a thermohydraulic model of the tank. The properties } \\
\text { include the following: } \\
\text { Composition } \\
\text { Solids settling rate } \\
\text { Density (solids and liquid phases) } \\
\text { Specific heat } \\
\text { Thermal conductivity } \\
\text { Shear stress vs. shear rate rheogram } \\
\text { Surface tension } \\
\text { Gas generation rate and composition } \\
\text { Coefficient of thermal expansion }\end{array}$ \\
\hline & $\begin{array}{l}\text { Evaluate slurry layer thermal and rheological properties supporting the } \\
\text { development of a thermohydraulic model of the tank. The properties } \\
\text { include the following: } \\
\text { Composition } \\
\text { Solids settling rate } \\
\text { Percent settled solids } \\
\text { Density } \\
\text { Thermal conductivity } \\
\text { Specific heat } \\
\text { Particle size distribution } \\
\text { Shear strength } \\
\text { Shear stress vs. shear rate rheogram } \\
\text { Gas generation rate and composition } \\
\text { Coefficient of thermal expansion } \\
\text { Surface tension }\end{array}$ \\
\hline
\end{tabular}


Table 4-1. Data Requirements. (2 sheets)

\begin{tabular}{|c|c|}
\hline Requatrements & Description \\
\hline Safety Analysis & $\begin{array}{l}\text { Characterize physical and chemical properties of the crust to support } \\
\text { modeling of crust movement during gas generation and migration and to } \\
\text { assess the potential consequences of a gas explosion. } \\
\text { Quantitatively identify toxicological components and aerosols in the crust, } \\
\text { liquid, and slurry layers for analysis of the consequences of an explosion. } \\
\text { Identify reactive materials (chemicals) in the crust to evaluate the potential } \\
\text { for a secondary crust reaction. }\end{array}$ \\
\hline Mitigation & $\begin{array}{l}\text { Evaluate waste characteristics supporting the development of mixing, } \\
\text { heating, dilution and sonic mitigation options. Waste characteristics } \\
\text { include the following: } \\
\text { Specific gravity } \\
\text { Solids settling rate } \\
\text { Percent settled solids } \\
\text { pH } \\
\text { Weight percent and volume percent of centrifuged solids } \\
\text { Shear stress vs. shear rate rheogram } \\
\text { Particle size distribution } \\
\text { Shear strength } \\
\text { Composition (anions, cations, organics, radionuclides) }\end{array}$ \\
\hline
\end{tabular}

Further methods development is required. 
Table 4-2. Core Sample Analyses.

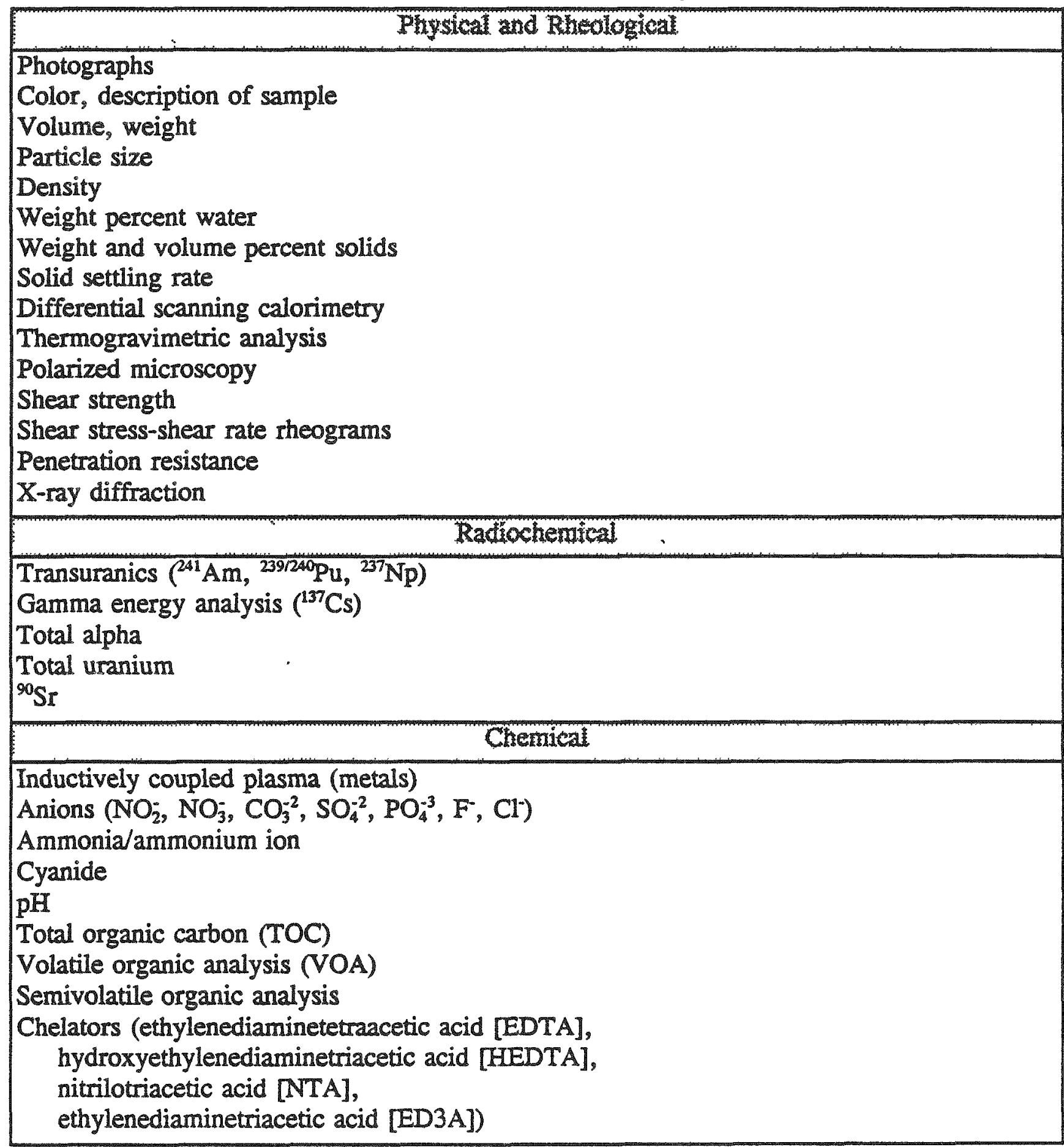


The radionuclide analyses will determine concentrations of ${ }^{268} \mathrm{Am},{ }^{99} \mathrm{Tc},{ }^{129} \mathrm{I},{ }^{239} \mathrm{Pu},{ }^{90} \mathrm{Sr}$, ${ }^{137} \mathrm{Cs}$, and ${ }^{237} \mathrm{~Np}$. These analyses involve conventional ion-exchange separations and solvent extraction separation followed by alpha energy analysis for the americium and neptunium. The physical property characteristics will include measurements of density, shear strength, solid settling rate, and percent settling of solids.

In 1991, a detailed data specification was developed for waste characterization activities. This data specification was used for preparing data quality objectives for the Flammable Gas Tank Safety program.

\subsubsection{Gas Monitoring}

A Standard Hydrogen Monitoring System (SHMS) has been designed and used at tank 241-SY-101. This system provides real-time analysis of hydrogen using dual chemical diffusion instruments made by the Whitaker Corporation. The system also has plumbing capabilities to grab samples at periodic intervals. Analysis of grab samples is performed at the Pacific Northwest Laboratory with a high-resolution mass spectrometer. Efforts are underway to include a gas chromatograph into the standard hydrogen monitoring system. Standard hydrogen monitoring system cabinets will be placed on each of the 25 Flammable Gas Watch List tanks. Figures 4-1 and 4-2 are photographs of a standard hydrogen monitoring system.

\subsubsection{Evaluating Waste Behavior}

The scope of this work is to gather and analyze data obtained from Tank Farm operations, waste sampling, gas monitoring, and relevant literature. It is important to analyze this data to determine trends and correlations, to provide an interpretation of processes occurring within the tank, and to highlight the need for additional data. Typical activities are as follows:

- Analyze recent and historical surface level and waste temperature data

- Interpret core sample and gas monitoring data

- Assess whether the information available on waste properties and behavior is sufficient or requires enhancement. 
WHC-SD-WM-SD-019 Rev. 0

This page intentionally left blank. 
WHC-SD-WM-SD-019 Rev. 0

Figure 4-1. Hydrogen Monitoring System (Closed Cabinet).

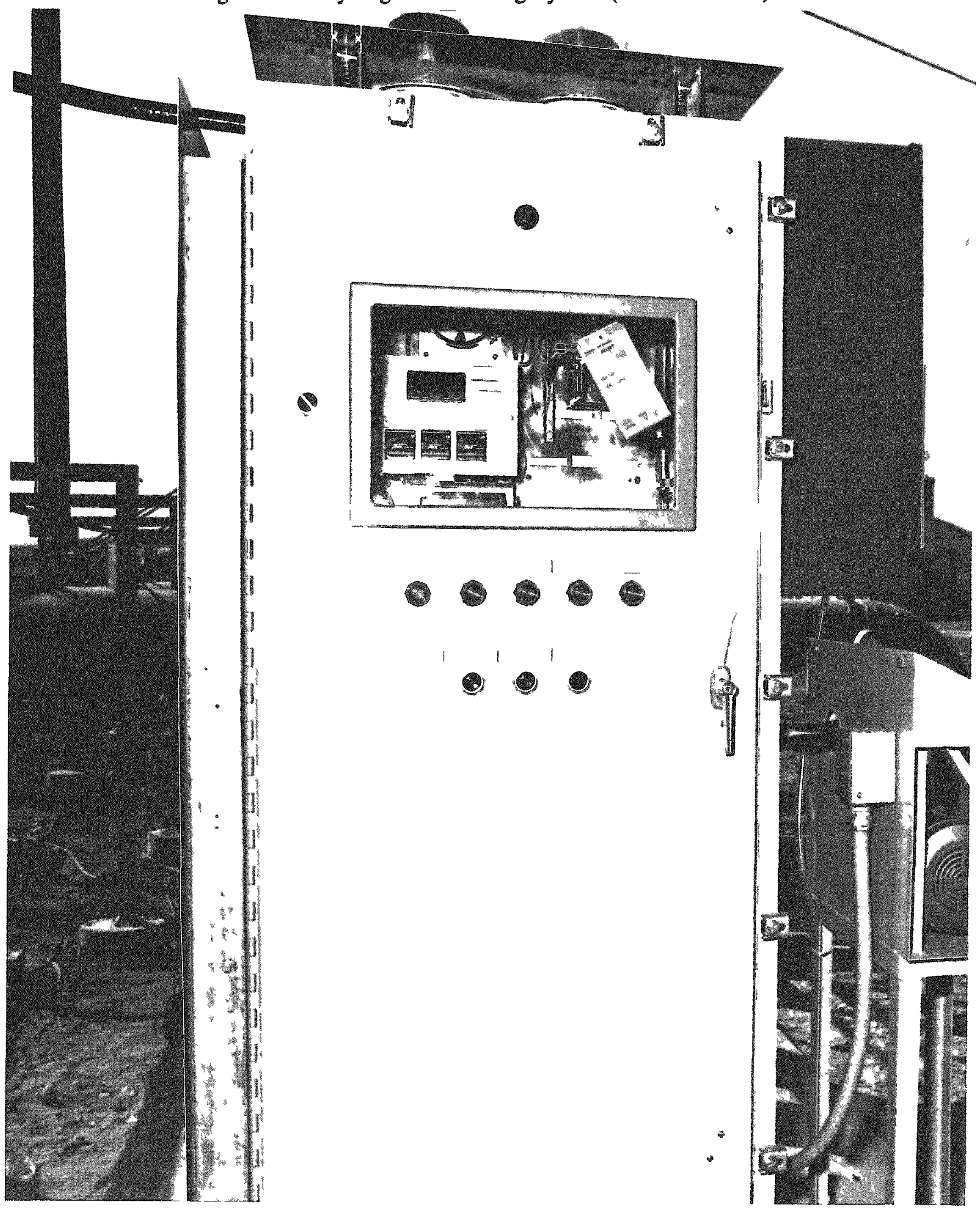


WHC-SD-WM-SD-019 Rev. 0

This page intentionally left blank. 
WHC-SD-WM-SD-019 Rev. 0

Figure 4-2. Hydrogen Monitoring System (Open Cabinet).
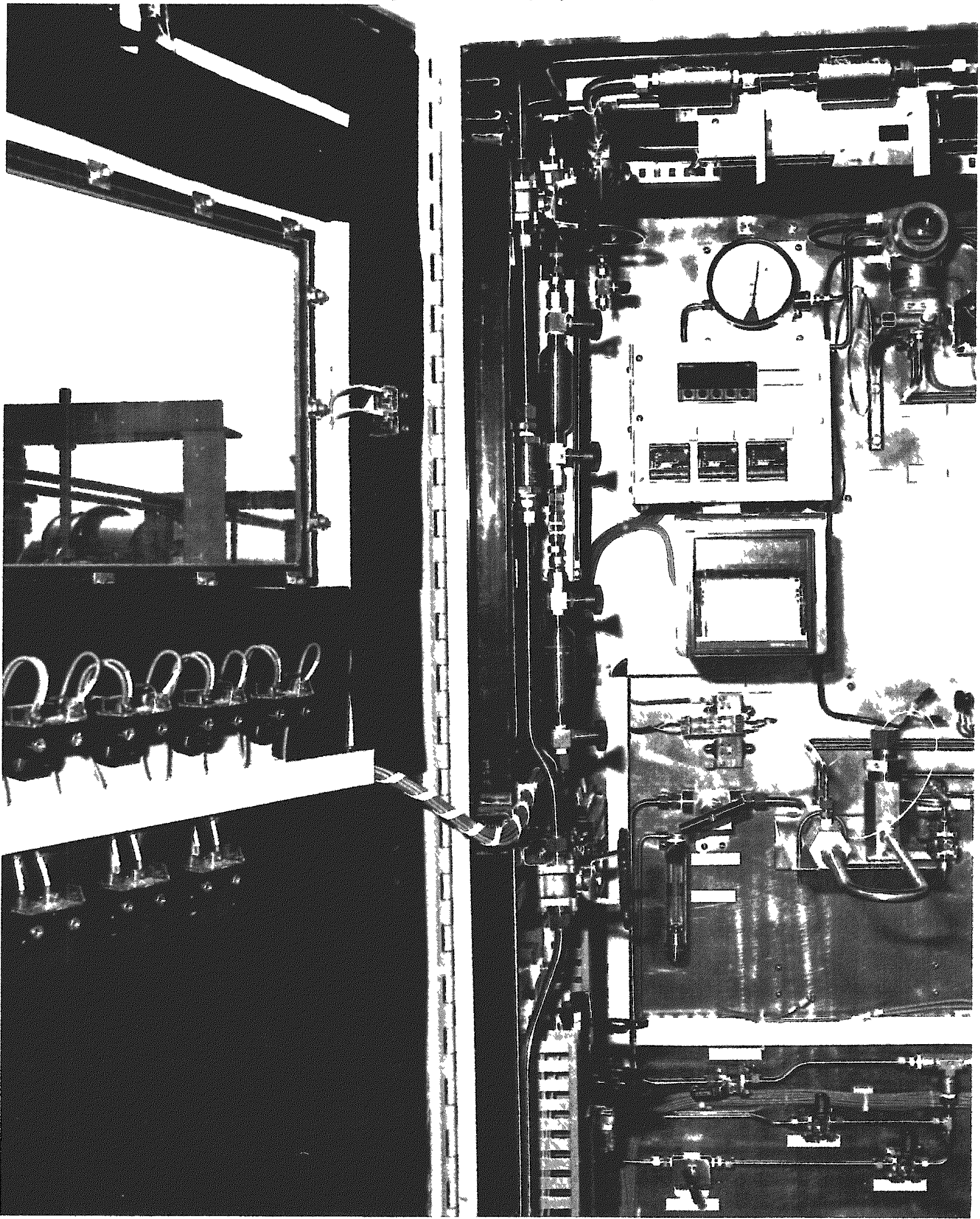
WHC-SD-WM-SD-019 Rev. 0

This page intentionally left blank. 


\subsection{TECHNOLOGY}

\subsubsection{Laboratory Studies}

Laboratory studies with synthetic and actual waste samples are essential for understanding the mechanisms for gas generation, retention, and release. In addition, the studies provide information for safety analyses and for engineering of mitigation options.

4.2.1.1 Gas Generation Reaction Mechanisms and Kinetics. This task will determine the stoichiometry, mechanisms, and kinetics of the gas-generating reactions. Experimental studies will determine the basic information about physical and chemical reactions in the waste, for example:

- The important parameters affecting gas generation

- The chemical mechanisms producing reactive gases such as $\mathrm{H}_{2}, \mathrm{~N}_{2} \mathrm{O}$ and $\mathrm{NH}_{3}$

- The part that radiation plays in gas generation.

4.2.1.2 Stoichiometry, Kinetics, and Mechanisms of Reactions. This task will investigate the stoichiometry, mechanisms, and kinetics of gas-generating reactions in Hanford waste.

The following approach will be used:

- Reaction stoichiometries will be determined by using simple systems of critical reactants (e.g., $\mathrm{NaNO}_{2}$ and HEDTA). The goal will be to identify and determine the amount of gaseous, solid, and soluble organic and inorganic products produced per mole of reactants.

- Reactivities of functional groups present in the reactive complexants will be isolated by using simple model compounds and isotopic tracers. For example, HEDTA is a reactive complexant; composed of alcohol, amine, and carboxylate groups. The reactivities of these groups will be investigated using simple molecules and ${ }^{13} \mathrm{C},{ }^{2} \mathrm{H}$ (deuterium), and ${ }^{15} \mathrm{~N}$ labeled functional groups.

- Functional groups in the reactive complexants will be traced with isotopic labels, and their behavior will be determined. The behavior will be compared with the model compounds.

- Reaction kinetics will be investigated using pseudo first-order conditions to allow examination of the effect of changing the concentration of one particular reactant. Each of the critical reactants or factors will be investigated.

- Parameters for the Arrhenius equation will be determined by running reactions over a range of temperatures. 
Various measurements will be taken to follow the process of the reaction in these experimental studies. These measurements include the volume and composition of gas produced, the increase in system pressure resulting from gas production, and the composition of the reactants.

4.2.1.3 Radiation Effects. Hanford tank wastes are highly alkaline to prevent excess corrosion of the steel liners. They have also been stored for many years thereby being exposed to high radiation doses. In such an environment, many reactions can occur that will change the chemical nature of the waste constituents. Researchers at the Argonne National Laboratory have conducted detailed evaluations on the effects of irradiation on Hanford waste; their results are summarized below.

The research goal was to examine the mechanisms of radiolytic and radiolytically induced thermal generation of gases in solutions and slurries simulating Hanford waste. Because the radioactive isotopes in the tanks are predominantly beta and gamma emitters, a ${ }^{60} \mathrm{Co}$ gamma source accurately simulates their radiolytic effects. The radiolytic sources for $\mathrm{H}_{2}$ are $\mathrm{e}_{\mathrm{aq}}^{-}$and its predecessors and $\mathrm{H}$ atoms. Direct radiolysis of the water generates some $\mathrm{H}_{2}$ (generation rate, or $\mathrm{G}$, for $\mathrm{H}_{2}$ is $\mathrm{G}=0.03$ of $\mathrm{H}_{2}$ molecules per $100 \mathrm{eV}$ of energy absorbed by water), and an additional amount comes from the hydrogen abstraction reaction $\mathrm{H}+\mathrm{RH} \rightarrow \mathrm{H}_{2}+\mathrm{R} \bullet$; the added yield correlates well with the rate constants measured for hydrogen abstraction. Nitrate scavenges $\mathrm{e}_{\mathrm{aq}}^{-}$and its predecessors, whereas nitrite $\left(\mathrm{No}_{2}^{-}\right)$is the major $\mathrm{H}$-atom scavenger. Computer modeling shows that if nitrate is above $0.5 \mathrm{M}$, and nitrite is above $2 \mathrm{M}$, the addition of other scavengers will have little effect on the yield of $\mathrm{H}_{2}$.

Generating nitrous oxide $\left(\mathrm{N}_{2} \mathrm{O}\right)$ requires the presence of organic molecules; however, the nitrogen atoms in $\mathrm{N}_{2} \mathrm{O}$ come from inorganic sources $\left(\mathrm{NO}_{2}^{-}, \mathrm{NO}_{3}^{-}\right)$. The dependence of the $\mathrm{N}_{2} \mathrm{O}$ yield on the dose rate suggests that it is produced by a first-order reaction of a radiolytic intermediate competing with a second-order reaction of the same intermediate. As the temperature increases, the first-order reaction speeds up and becomes dominant. Oxygen is efficiently destroyed in the presence of organic molecules. Small yields of ammonia were measured, and they increased linearly with dose indicating ammonia is produced from radiolysis of an intermediate. The nitrogen in $\mathrm{NH}_{3}$ comes from organic chelators such as EDTA.

Gas yields in solution depend only weakly on temperature (for temperatures less than $60^{\circ} \mathrm{C}$ ). The yield of $\mathrm{H}_{2}$ in slurries at $30^{\circ} \mathrm{C}$ is significantly lower than in solution. As the temperature increases, more of the solids are soluble, and the yields approach those in solution.

The rate of thermal gas generation increases upon preirradiation, reaches a maximum (at approximately $20 \mathrm{Mrad}$ ), then declines. Therefore, the known radiolytic degradation products of chelators (NTA, IDA, glycolate, glyoxylate, formaldehyde, formate, oxalate, and hydroxylamine) were examined for their roles in the thermal generation of $\mathrm{H}_{2}$ and $\mathrm{N}_{2} \mathrm{O}$ at 
$60^{\circ} \mathrm{C}$. Among the degradation products, only glyoxyate and formaldehyde generated $\mathrm{H}_{2}$ at significant rates. Hydroxylamine generated $\mathrm{N}_{2} \mathrm{O}$ and $\mathrm{N}_{2}$ at significant rates with standard waste simulants.

Formaldehyde is a proposed intermediate for the production of hydrogen from chelators. The rate of hydrogen evolution from formaldehyde has been measured under experimental conditions and at temperatures relevant to waste tank conditions. Rate constants and activation energies for formaldehyde and glyoxylate have been determined. The fraction of formaldehyde producing $\mathrm{H}_{2}$ increased with decreasing formaldehyde, thereby increasing $\left[\mathrm{OH}^{-}\right]$and increasing temperature.

Minor waste constituents showed no catalytic effects on gas generation rates. In solution or slurry, only radiolytically produced Pd intermediate (possibly metallic Pd) strongly retains $\mathrm{H}_{2}$, but it does not reduce the rate of its generation. Radiolytic yields of $\mathrm{N}_{2} \mathrm{O}$ are strongly reduced by $\mathrm{Cr}$ (III) but not by other minor components. "Loose" and "tight" gases have been found in irradiated slurry. "Loose" gas can be removed by bubbling; "tight" gas can be released only by dissolution of the slurry. It is estimated that only 10 percent of the degradation of organics must produce formaldehyde to account for the $\mathrm{H}_{2}$ yield in tank 241-SY-101.

Some conclusions are as follows: $\mathrm{NO}_{2}$ is the major oxidizing radical, and its reaction products probably include glyoxylate and formaldehyde as thermal precursors for $\mathrm{H}_{2}$ and hydroxylamine for $\mathrm{N}_{2} \mathrm{O}$. About 30 percent of the $\mathrm{H}_{2}$ comes from radiolytic reactions and the rest from thermal reactions.

4.2.1.4 Testing Samples of Actual Wastes. Tests will be conducted on waste retrieved from tanks (e.g., tanks 241-SY-101 and 241-SY-103) to determine gas generation kinetics and gas solubility for $\mathrm{NH}_{3}, \mathrm{~N}_{2} \mathrm{O}$ and $\mathrm{N}_{2}$. The effects of heating and dilution on gas production will also be evaluated.

4.2.1.5 Gas Retention Studies. The rheological behavior of tank waste is critical to characterizing its tendency to retain and periodically release gas. Early investigations concluded that gas bubbles are retained by the waste slurry which has settled to the bottom of the tank (sludge). Physical mechanisms responsible for the retention of these bubbles are not well understood, but the yield strength and viscosity of the waste are expected to be the most important properties contributing to these mechanisms. The presence of gas bubbles in the sludge is also expected to affect its physical properties, but there are no literature data available to asses these effects. Objectives of these studies include the following: explaining the mechanisms contributing to gas bubble retention and release from waste sludge, understanding how bubbles affect the sludge physical properties pertinent to bubble retention, developing correlations of these physical properties to include in computer models, for example, and collecting experimental data on the physical properties of simulated sludges with bubbles, for example, viscosity and yield strength. 
Gas bubbles being released from waste in tank 241-SY-101 cause or are caused by waste motion. Accordingly, dynamic properties of the sludge, such as its rheology, are important to the release mechanism. In contrast, the mechanisms for bubble retention appear to depend more on the forces acting on bubbles in stagnant sludge, for example, surface tension.

\subsubsection{Developing Tank Model Applications}

Analytical evaluations support safety analyses, enhance an understanding the processes responsible for episodic gas releases, and support development of mitigation methods.

4.2.2.1 Thermo-Physical Modeling. Existing computer codes that model convective turnover of a fluid do not account for all of the phenomena needed to explain the physical processes taking place in tank 241-SY-101. For instance, bubble formation and dynamics are needed to simulate the periodic gas release in the tank. The mathematical models that describe these processes, as well as sludge rheological properties, are programmed into a computer code that describes simultaneous interactions of fluid dynamic forces in the waste tank during a gas release event. Computer programs will need to be validated against measurements made in the tank and in model systems.

4.2.2.2 Gas-Flow Model. Computer models have been developed to describe the transport and distribution of vented slurry gases within the tank dome and throughout the ventilation system of a tank farm. This model has been used to estimate the amount of gas required to reproduce the pressure pulses observed in tank 241-SY-101 after gas release events. The model calculates hydrogen concentration as a function of time in the tank and ventilation system. This model has been used to simulate each gas release event that has occurred in tank 241-SY-101 since April 1990.

\subsubsection{Developing Techniques for Characterizing Chelators and Chelator Fragments}

Chelators and chelator fragments are the major organic reactants responsible for hydrogen and nitrous oxide generation in Hanford radioactive liquid waste. Analytical methods exist for some of these organic analytes; but other nonvolatile, polar, and high molecular weight compounds (such as chelators and chelator fragments) are not amenable to Environmental Protection Agency-accepted methodology (gas chromatography or gas chromatography/mass spectrometry). Nonvolatile components will require advanced organic analytical techniques in order to determine their identity and concentration in tank waste. Determination of the organic species may be amendable to techniques such as supercritical fluid chromatography/ mass spectrometry, liquid chromatography/mass spectrometry, microcolumn, and ion bombardment. Organometallics can be analyzed by liquid chromatography/mass spectrometry-ICP/mass spectrometry which will enable the organic moiety and the associated metal to be determined simultaneously. 
Considerable progress has been made in identifying organic compounds in tank 241-SY-101 waste samples. Chelators, chelator fragments, and several carboxylic acids have been measured in the core segment samples using derivatization gas chromatography/mass spectrometry. The major components detected were ethylenediaminetetraacetic acid (EDTA), nitroso-iminodiacetic acid (NIDA), nitrilotriacetic acid (NTA), citric acid, succinic acid, and ethylenediaminetriacetic acid (ED3A). In all six samples analyzed, the highest concentrated chelator was EDTA.

The combined techniques of derivatization gas chromatography/mass spectrometry and liquid chromatography have accounted for approximately 71 to 93 percent of the total organic carbon which amounts to 1 percent of the tank waste.

\subsubsection{Developing Sampling Techniques}

It is not clear why high-level radioactive liquid waste stored in some Hanford waste tanks retains gas while waste stored in other tanks does not. It is reasonable to expect that a waste sample captured from a Flammable Gas Watch List tank with the retained gas "intact" could shed some light on this issue.

The Retained Gas Sampler work package will fund development and deployment of equipment for sampling waste in a Flammable Gas Watch List tank to measure the composition and fraction of gas in the waste. Two key parts to this system are:

1. A device to be inserted into a tank that is capable of capturing and isolating part of the stored waste

2. Laboratory equipment to remove, measure, and analyze the gaseous constituents of the waste

Waste samples obtained with the Retained Gas Sampler will allow measurements of gas concentrations in all states of matter in tank waste to be made. Some gas will be in the gas phase; the rest will be dissolved in the liquid phase and adsorbed in the solid phase. The Flammable Gas Tank Safety Program is interested in obtaining the following information with the Retained Gas Sampler.

The Retained Gas Sampler design is produced from by modifying the Universal Sampler, (see Figure 4-3). After a sample is taken, it will be extruded from the sampler and placed into an extractor system where the waste can be manipulated and gas removed from it for analysis. Figures 4-4 and 4-5 show the operations of the Universal Sampler. 
Table 4-3. Data Priority and Uncertainties for Retained Gas Sampler System.

\begin{tabular}{|l|c|c|c|}
\hline \multicolumn{1}{|c|}{} & & \multicolumn{3}{c|}{ Rejative uncertainty } \\
\hline Void fraction & $3.0 \%$ & $100 \%$ & $20 \%$ \\
\hline Hydrogen & $30.0 \%$ & $17 \%$ & $3 \%$ \\
\hline Nitrogen & $30.0 \%$ & NA & $20 \%$ \\
\hline Nitrous Oxide & $30.0 \%$ & NA & $20 \%$ \\
\hline Ammonia & $5.0 \%$ & NA & $20 \%$ \\
\hline Other minor gases $\mathrm{CCH}_{2}, \mathrm{CO}_{2}, \mathrm{CO}$ & $0.5 \%$ & NA & $100 \%$ \\
\hline
\end{tabular}

\subsection{SAFETY DOCUMENTATION AND UNREVIEWED SAFETY QUESTION RESOLUTION}

Several different types of documents have been prepared for the Flammable Gas Tank Safety issue: safety assessments, topical reports, criteria for adding and removing tanks from the Watch List, as well as documents to resolve the unreviewed safety question. The Interim Safety Basis is a review and evaluation of existing documentation, including safety assessments, safety analysis reports, justifications for continued operation, and old and new safety reports. In some cases, topical reports may be required to address certain aspects of the safety issue. These topical reports, in turn, are used to support safety analyses conducted for specific work activities. Examples of such topical reports are as follows:

Tank 241-SY-103 Hazard Assessment, WHC-SD-WM-SAR-061, G. L. Fox, Jr., et al., October 1993.

Flammable Gas Safety Issue Review: Tank 241-SY-101, WHC-EP-0578, D. E. Simpson, et al., September, 1992.

Tank 241-SY-101 Crust Burn Analysis, WHC-SD-WM-SAR-046, G. L. Fox, Jr., et al., June, 1992.

Response of Tank 241-SY-101 to a Postulated Hydrogen Burn, WHC-SD-WM-TI-426, G. L. Fox, Jr., et al., July 1990. 
Criteria have been developed to evaluate and disposition the Flammable Gas Watch List tanks. These tanks may be assigned to a category where operating restrictions are reduced or eliminated, or recommendations will be made for tank characterization activities preceding removal from the Watch List. Activities include the following:

- Collecting data relevant to hydrogen generation and release

- $\quad$ Reviewing the cause for each tank being on the Watch List and determining whether the cause is still valid

- Preparing a report documenting the review results and recommending a change of category or the collection of additional information and surveillance data.

A technical basis will be prepared for evaluating the unreviewed safety question for Flammable Gas Watch List tanks. Activities include collecting and evaluating available data, performing technical evaluations of key issues, and documenting this work as appropriate. Specific tasks for this activity include the following:

- Updating and maintaining a comprehensive database on the Flammable Gas Watch List tanks based on historical documents and process data

- Evaluating tank data for gas composition, pressure spikes and chemistry as they relate to safety issue resolution

- Updating the unreviewed safety question screening evaluation and safety evaluation for the Flammable Gas Watch List tanks in the AW and SY Tank Farms using updated Watch List criteria and the unreviewed safety question database

- Providing general guidelines for resolving the unreviewed safety question for all Flammable Gas Watch List tanks

- Preparing specific documentation for resolving the unreviewed safety question. The approach will be to close the unreviewed safety question on the 241-SY Tank Farm first, then the remaining tanks

\subsection{EQUIPMENT AND INSTRUMENTATION UPGRADES}

The Flammable Gas Tank Safety Program is buying new equipment for the Hanford tank farms to upgrade ventilation and monitoring systems. 
Figure 4-3. Universal Sampler.
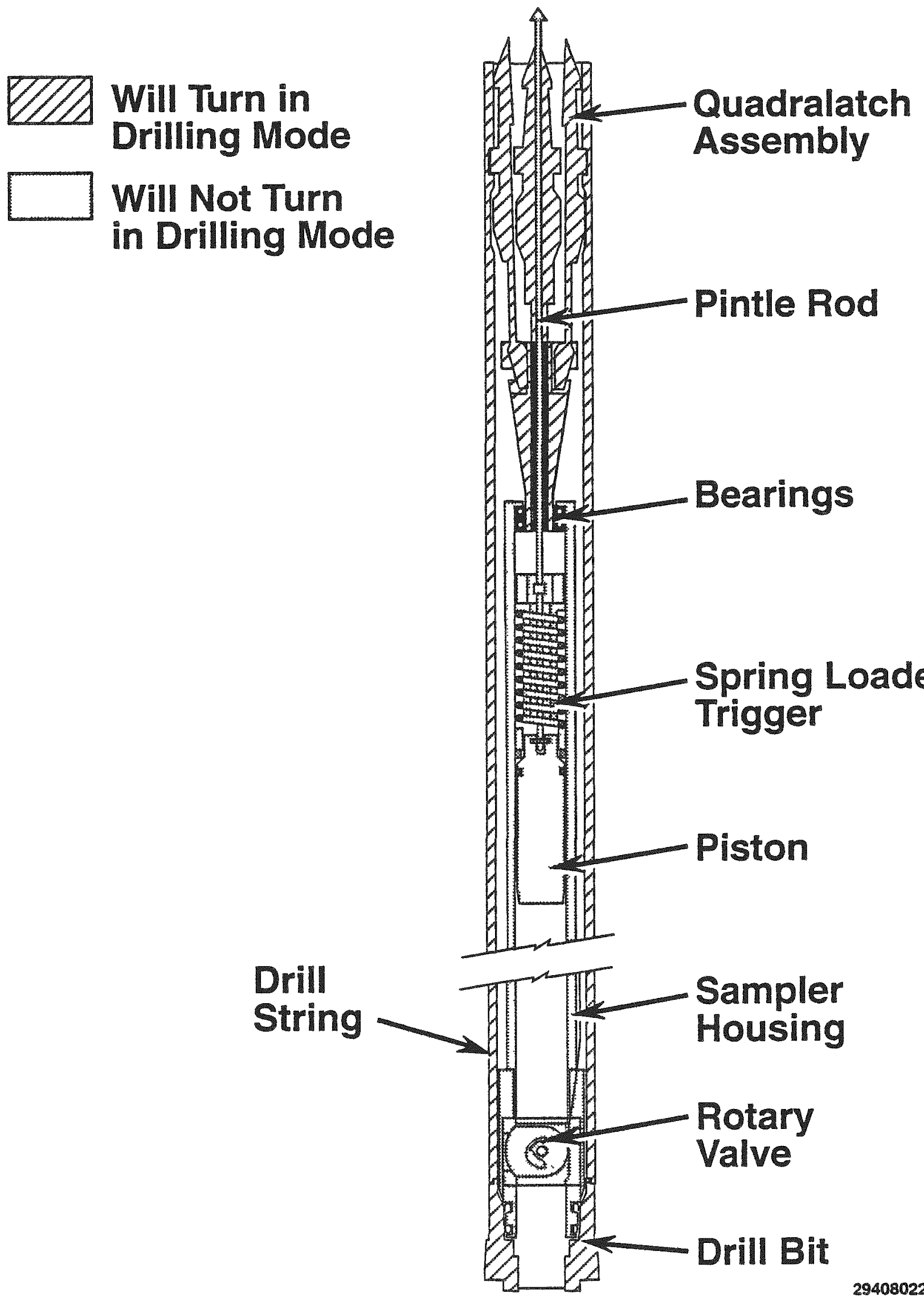

Will Not Turn in Drilling Mode 


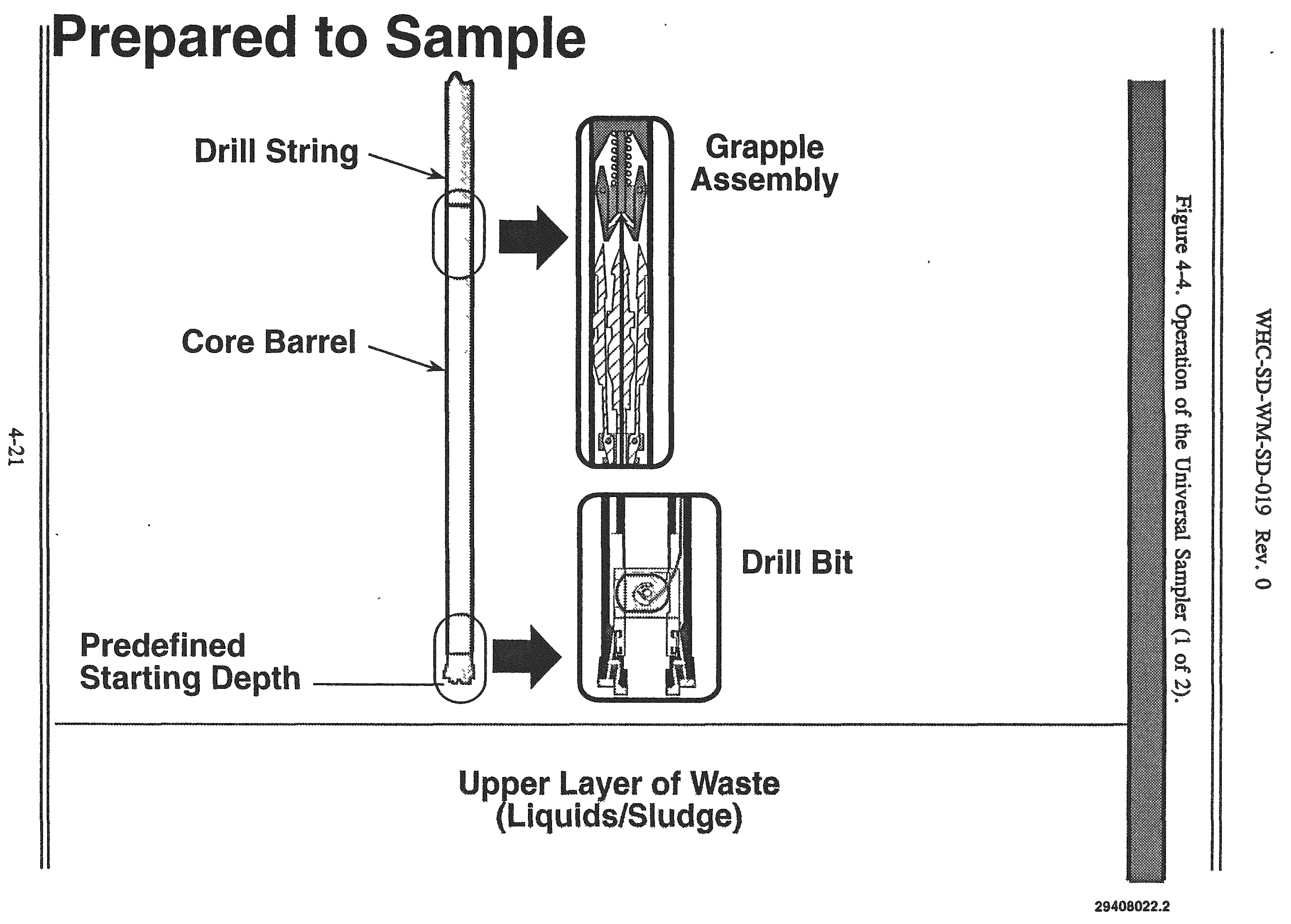




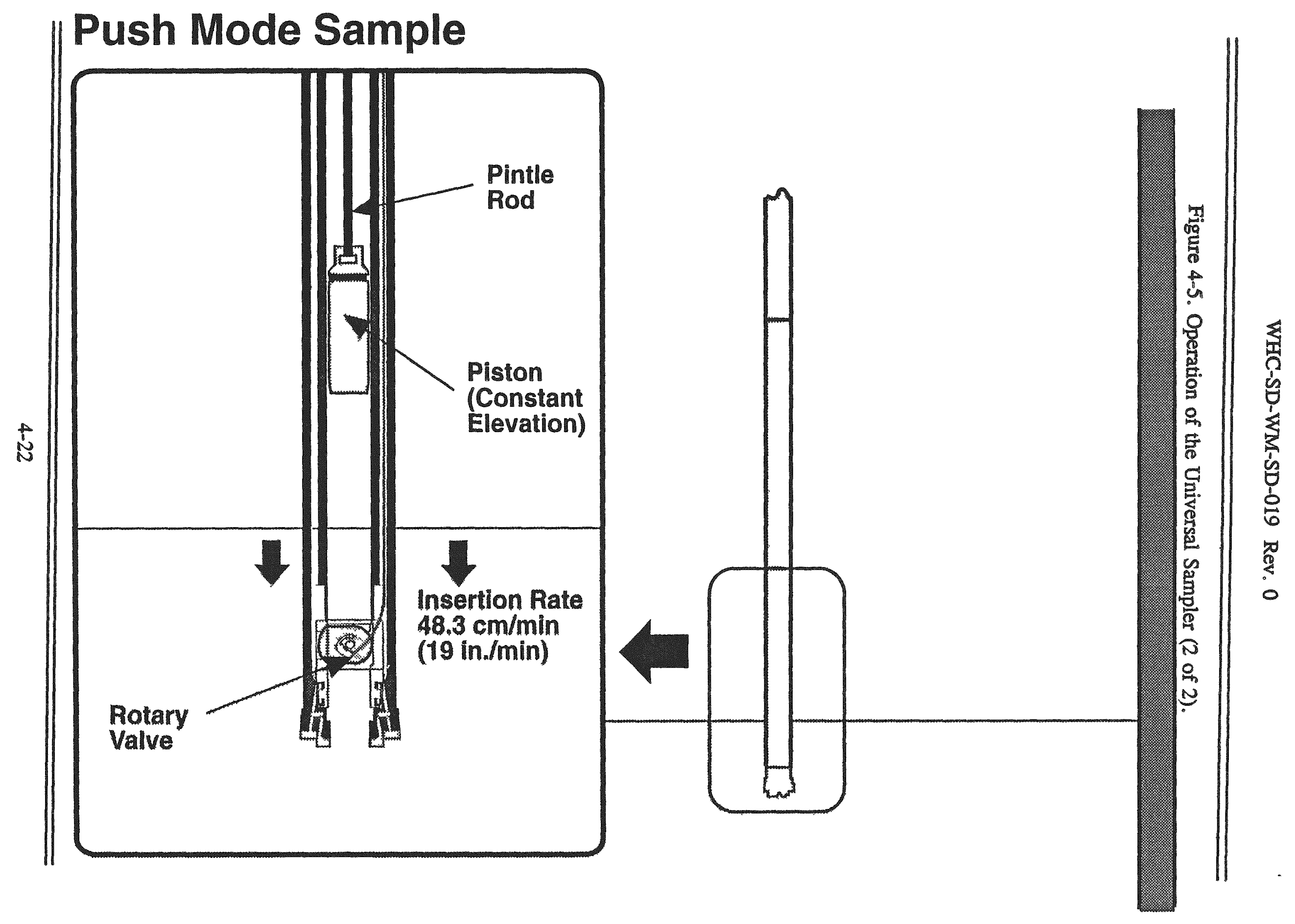




\subsubsection{Ventilation Upgrades}

Permanent inlet filters will be designed, fabricated, and installed on tanks 101-SY, 102-SY, and 103-SY to improve the ventilation system for the 241-SY Tank Farm. These assemblies will enable increased flow, filter possible emissions during tank pressurization, and provide better flow and pressure control. The work includes writing procedures and coordinating Job control system documents and project engineering. A spark-resistant fan will be designed and built to replace the existing fan in the 241-SY Tank Farm primary ventilation system. The backup exhauster at the 241-SY Tank Farm will also be replaced. Similar upgrades are planned for the 241-AW and 241-AN Tank Farms.

\subsubsection{Farm Tank Monitor and Control System (TMACS)}

The TMACS will be installed in the 241-SY and 241-AN Tank Farms, as well as in other Hanford Site tank farms by the tank farm upgrades. In the 241-AN Tank Farm, selected intank and structural temperature elements will be connected to the system. In the 241-SY Tank Farm, in-tank and structural temperature elements, as well as other parameters, will be connected. The parameters are vent flow (101-SY), tank pressure (101-SY), and hydrogen concentration (101-SY and 103-SY). These instruments and sensors will be monitored on a continuous basis by the TMACS.

This expansion of the TMACS consists of installing local signal conditioning equipment at or near each tank. The signal conditioners will communicate via a shared cable with a central computer. The signal conditioners accept standard instrumentation and allow for future expansion.

\subsubsection{Gas Monitoring}

The Standard Hydrogen Monitoring System (SHMS) monitors hydrogen evolved from waste. (Air, nitrous oxide $\left[\mathrm{N}_{2} \mathrm{O}\right]$, ammonia $\left[\mathrm{NH}_{3}\right]$, water vapor, carbon dioxide $\left[\mathrm{CO}_{2}\right]$, carbon monoxide [CO] and other gaseous constituents may also be present.) The system includes hydrogen-specific monitors, a grab sampler to identify other gaseous constituents, and the gas-sampling system (tubing, valving, vacuum pumps, etc.) that supports the operation of the instrumentation. The system uses Whitaker electrochemical cells and is located in an environmentally controlled cabinet near the tank.

A SHMS will be installed on each Flammable Gas Watch List tank. For tanks with active ventilation, the SHMS will be connected to the ventilation header; for tanks with passive ventilation, sampling probes will be installed in the dome space. Each SHMS will eventually be connected to the TMACS. 


\subsubsection{Temperature Measurement}

The Multi-Function Instrument Tree (MIT), designed by the Los Alamos National Laboratory, will be installed in all double-shell tanks on the Flammable Gas Tank Watch List. The MIT can contain up to 24 thermocouples spaced vertically along the tree (depending upon the liquid and sludge levels within a waste tank) and can sample the vapor space from three locations above the waste to determine the differential pressure between the tank and atmosphere. In addition, the MIT can insert a validation probe down the assembly center to verify the temperature at any level.

\subsubsection{Waste Surface Level Measurement Upgrade}

The existing waste surface-level instrument is a reel-type conductivity gauge with a lengthy history of maintenance problems. The gauge uses a probe that is lowered to contact the waste surface. Because the probe contacts the waste, crystal grows on it which interferes with its ability to detect the change in conductivity that marks the surface. The raising and lowering action causes mechanical wear resulting in repair and upkeep problems. In addition, the gauge requires a constant instrument air purge to prevent moisture from interfering with the conductivity sensing. In many single-shell tank farms, this is the only use of instrument air, which is expensive.

Waste tank surface-level monitoring needs for the Hanford tank farms have been assessed, and available technologies examined for applicability. Surface level measuring technologies which have been examined include radar, conductivity, buoyancy/tension wire, and optical/laser. The buoyancy/tension wire gauge is considered the best option available. It will operate on non-conductive liquids or solids, and it requires no air purge. The build up of salt precipitates on the buoyancy float, and the effect of precipitates on the measured surface level is minimal.

\subsection{MUTIGATION}

Considerable effort has gone into methods for evaluating and resolving the episodic gas release behavior being exhibited in tank 241-SY-101. The following criteria are appropriate:

- Maintaining the tank dome space at a value less than 25 percent of the lower flammability limit

- Maintaining a negative pressure in the dome space

- Preventing uncontrolled reactions of the gas and waste

- Maintaining tank integrity 
- Maintaining disposal and retrieval options

- Preventing unacceptable releases of toxic or radiological substances

- Preventing unacceptable alteration of crust and/or liquid waste properties

- Preventing excessive build-up of gas in the slurry

- Maintaining and operating the mitigation equipment with ease

- Minimizing overt actions (i.e., be passive to the maximum extent that is possible).

The selection of any near-term mitigation option also must consider the following:

- Availability

- Reliability

- Impact on long-term remediation

- Surveillance options.

A variety of options have been proposed. Table 4-4 provides a short list of features for each option, the possible approaches to affect the option, the information required for evaluating the option, the potential issues that require resolution, and the means by which the program will acquire the requisite data and analyses to solve the issues and provide the knowledge required for the evaluation studies.

For more detailed information about the migigation program, see WHC-EP-0550, Tank 101-SY Flammable Gas Mitigation Test Project Plan (Lentsch 1992).

\subsection{RELATIONSHUP BETWEEN WORK ACTIVITIES AND PROGRAM LOGIC}

Table 4-5 provides a brief summary of how work activities relate to specific elements of the program logic. 
Table 4-4. Mitigation Options. (4 sheets)

\begin{tabular}{|c|c|c|c|c|c|}
\hline Option & $\therefore$ Features & Alpproaches & Reguired lnowledges & (4. & Mernit to obthin linovledge \\
\hline $\begin{array}{l}\text { Circulation of } \\
\text { tank contents }\end{array}$ & $\begin{array}{l}\text { Promote continuous release } \\
\text { of gas } \\
\text { Retard crust buildup } \\
\text { Dissolve crust }\end{array}$ & $\begin{array}{l}\text { Pump waste; options } \\
\text { include bottom-to-top } \\
\text { and bottom only } \\
\text { Mechanical stirring }\end{array}$ & $\begin{array}{l}\text { Physical properties of waste } \\
\text { and crust } \\
\text { Chernistry of waste } \\
\text { Depth of various layers } \\
\text { Mechanism of gas } \\
\text { generation } \\
\text { Efficiency of mixing and } \\
\text { circulation } \\
\text { Method for circulator }\end{array}$ & $\begin{array}{l}\text { Presence of crust } \\
\text { Pump life-time } \\
\text { Growth/dissolution of } \\
\text { crust } \\
\text { Purnp requirements } \\
\text { Verify that the method } \\
\text { works }\end{array}$ & $\begin{array}{l}\text { Sample waste } \\
\text { Characterize tank } \\
\text { Model tank } \\
\text { Evaluate mechanisms } \\
\text { Design study }\end{array}$ \\
\hline
\end{tabular}


Table 4-4. Mitigation Options. (4 sheets)

\begin{tabular}{|c|c|c|c|c|c|}
\hline Aption & Peature & Approphes & Required lnowledge & ४ै. & Mens to obtain linouledge \\
\hline $\begin{array}{l}\text { Transfer tank } \\
\text { contents }\end{array}$ & $\begin{array}{l}\text { Reduce volume of waste, } \\
\text { thereby lowering total gag } \\
\text { production }\end{array}$ & $\begin{array}{l}\text { Pump waste to another } \\
\text { tank }\end{array}$ & $\begin{array}{l}\text { Physical properties of waste } \\
\text { Compatibility with other } \\
\text { waste } \\
\text { Mechanism of gus } \\
\text { production } \\
\text { Depth of various layers } \\
\text { Available tanil space } \\
\text { Method of purmping }\end{array}$ & $\begin{array}{l}\text { Tank space } \\
\text { Gas generation of } \\
\text { transferred waste } \\
\text { Verify that the method } \\
\text { works }\end{array}$ & $\begin{array}{l}\text { Sample waste } \\
\text { Characterize tank } \\
\text { Evaluate mechanisms } \\
\text { Build new tanks } \\
\text { Evaluate data on other tarls } \\
\text { Engineering study }\end{array}$ \\
\hline $\begin{array}{l}\text { Sparge with } \\
\text { inert gas }\end{array}$ & $\begin{array}{l}\text { Lower gas production } \\
\text { Circulation } \\
\text { Removes other gases } \\
\left(\mathrm{O}_{3}, \mathrm{~N}_{2} \mathrm{O}\right)\end{array}$ & $\begin{array}{l}\text { Install lances } \\
\text { Circulate waste to a } \\
\text { location (some other } \\
\text { position) for gas } \\
\text { injection and retum }\end{array}$ & $\begin{array}{l}\text { Physical properties of waste } \\
\text { Gas content in slurry and } \\
\text { sludge } \\
\text { Mechanism of gas } \\
\text { production } \\
\text { Solubility of gas }\end{array}$ & $\begin{array}{l}\text { May need to dilute the } \\
\text { waste } \\
\text { Number and location of } \\
\text { lanes } \\
\text { Effect on ventilation } \\
\text { system } \\
\text { Verify that the method } \\
\text { works } \\
\text { Distribution of gassy } \\
\text { waste }\end{array}$ & $\begin{array}{l}\text { Sample waste } \\
\text { Evaluate Mechanisms } \\
\text { Tank modeling } \\
\text { Ventilation study } \\
\text { Design and engincering } \\
\text { study } \\
\text { Tank instrumentation }\end{array}$ \\
\hline
\end{tabular}


Table 4-4. Mitigation Options. (4 sheets)

\begin{tabular}{|c|c|c|c|c|c|}
\hline Option & Penture 8 & Approache & Required knowledse & Isvere & Means to oblail luovlodge \\
\hline $\begin{array}{l}\text { Ultrasonic } \\
\text { agitation and } \\
\text { sonic agitate }\end{array}$ & $\begin{array}{l}\text { Cause release of guses at } \\
\text { desired timing intervals }\end{array}$ & $\begin{array}{l}\text { Use ullrasound to } \\
\text { enhance bubble transport } \\
\text { and release }\end{array}$ & $\begin{array}{l}\text { Required frequency } \\
\text { Number of transducers } \\
\text { Time application (pulsed or } \\
\text { continuous) } \\
\text { Mechanism of gas } \\
\text { production } \\
\text { Bubble behavior }\end{array}$ & $\begin{array}{l}\text { Heat deposited in waste } \\
\text { Means to attach } \\
\text { transducers } \\
\text { Verify that the method } \\
\text { works }\end{array}$ & $\begin{array}{l}\text { Evaluate mechanisms } \\
\text { Tank modeling } \\
\text { Laboratory testing and } \\
\text { analyses and demonstration } \\
\text { Tank instrumentation }\end{array}$ \\
\hline $\begin{array}{l}\text { Transfer, } \\
\text { dilute, and } \\
\text { agitate }\end{array}$ & Control release of gases & $\begin{array}{l}\text { Transfer } 100,000 \text { gal of } \\
\text { slurry } \\
\text { Dilute with } 10,000 \text { gal of } \\
\text { water } \\
\text { Maintain opening in } \\
\text { crust } \\
\begin{array}{l}\text { Provide mechanical } \\
\text { energy to trigger release } \\
\text { of gas }\end{array}\end{array}$ & $\begin{array}{l}\text { Solubility of waste } \\
\text { Crust properties } \\
\text { Waste compatibility } \\
\text { Amount and location of } \\
\text { "mechunical energy" } \\
\text { Efficiency of mixing and } \\
\text { circulation } \\
\text { Mechanism of gas } \\
\text { production }\end{array}$ & $\begin{array}{l}\text { Presence of a crust } \\
\text { No free space in tank } \\
101-S Y \\
\text { Verify that the method } \\
\text { workg }\end{array}$ & $\begin{array}{l}\text { Sample waste } \\
\text { Evaluate mechasisms } \\
\text { Tank modeling } \\
\text { Evaluate data on other tanks } \\
\text { Design an engineering study } \\
\text { Build new tank space } \\
\text { Tank instrumentation }\end{array}$ \\
\hline
\end{tabular}


Table 4-4. Mitigation Options. (4 sheets)

\begin{tabular}{|c|c|c|c|c|c|}
\hline$\therefore$ Option & 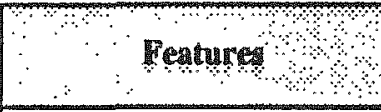 & Approaches & hequired Loviledg & 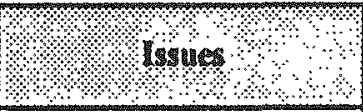 & Mean w pbtain knowlodge \\
\hline $\begin{array}{l}\text { Chemical } \\
\text { ireatment }\end{array}$ & $\begin{array}{l}\text { Destroy or remove } \\
\text { compounds that produce } \\
\text { gases } \\
\text { Dissolve crust }\end{array}$ & $\begin{array}{l}\text { In-situ application } \\
\text { Transfer waste to } \\
\text { treatment facility } \\
\text { Add gas absorber }\end{array}$ & $\begin{array}{l}\text { Characterization of waste } \\
\text { Mechanism of gas } \\
\text { production } \\
\text { ldentify gas absorbers }\end{array}$ & $\begin{array}{l}\text { Construction of } \\
\text { ureatment facility } \\
\text { Mixing of materials in the } \\
\text { waste } \\
\text { Verify that the method } \\
\text { works }\end{array}$ & $\begin{array}{l}\text { Sample wate } \\
\text { Evaluate mechanisms } \\
\text { Design an engineering study } \\
\text { Tank instrumentation } \\
\text { Pilot plant atudies }\end{array}$ \\
\hline $\begin{array}{l}\text { Thermal } \\
\text { Ireatment }\end{array}$ & $\begin{array}{l}\text { Change reaction rate that } \\
\text { generates gas for gas } \\
\text { generation }\end{array}$ & $\begin{array}{l}\text { Cool the lank (reduce } \\
\text { rate) } \\
\text { Heat the lank (destroy } \\
\text { compounds) }\end{array}$ & $\begin{array}{l}\text { Mechanism of gas } \\
\text { generation } \\
\text { Chemistry of waste } \\
\text { Method to heat or cool lank }\end{array}$ & $\begin{array}{l}\text { Tank corrosion } \\
\text { Effects of thermal change } \\
\text { Verify that the method } \\
\text { works }\end{array}$ & $\begin{array}{l}\text { Sample waste } \\
\text { Evaluate mechanisms } \\
\text { Design an engineering study } \\
\text { Tank instrumentation } \\
\text { Pilot plant atudies }\end{array}$ \\
\hline
\end{tabular}


Table 4-5. Relationship of Work Activities and Program Logic.

\begin{tabular}{|c|c|}
\hline Progenan activity & Logic element(s) \\
\hline $\begin{array}{l}\text { Characterization and evaluation } \\
\text { Waste Sampling (Core/Auger) } \\
\text { Gas Monitoring } \\
\text { Evaluation of Waste Behavior } \\
\text { (Data Analyses and Reports) }\end{array}$ & $\begin{array}{l}1.2 .1,1.2 .4 \\
1.2 .1,1.2 .4 \\
1.2 .4,1.2 .5,1.1 .1 .5\end{array}$ \\
\hline $\begin{array}{l}\text { Technology } \\
\text { Laboratory Studies } \\
\text { (Synthetic Waste: Radiolytic, Chemical } \\
\text { Mechanism, Gas Generation) } \\
\text { Tank Models (Flow, Phys., Thermal) } \\
\text { Development of Analytic Methods } \\
\text { (Organics, Physical Prop) } \\
\text { Development of Sampling Techniques (In Situ) }\end{array}$ & $\begin{array}{l}1.1 .1 .4,1.3 .1 .1,1.3 .1 .2 \\
1.1 .1 .6 \\
1.2 .1 \\
1.2 .1\end{array}$ \\
\hline $\begin{array}{l}\text { Safety documentation/USQ resolution } \\
\text { Safety Assessments } \\
\text { Hazard Analyses } \\
\text { Watch List Criteria } \\
\text { Resolution of USQ }\end{array}$ & $\begin{array}{l}1.2 .2,1.2 .3,1.4,1.5 \\
1.2 .6,1.2 .7,1.4,1.7 .4 \\
1.1 .1 .3,1.6 \\
1.4,1.5\end{array}$ \\
\hline Environmental Assessment & 1.2 .3 \\
\hline $\begin{array}{l}\text { Equipment and instrumentation } \\
\text { Ventilation Upgrades } \\
\text { TMACS/Repair TCs } \\
\text { Gas Monitors } \\
\text { Temperature } \\
\text { Surface Level } \\
\text { TV } \\
\text { Equipment Removal }\end{array}$ & $\begin{array}{l}1.7 \\
1.7 \\
1.7 \\
1.7 \\
1.7 \\
1.7 \\
1.7\end{array}$ \\
\hline Mitigation & 3.0 \\
\hline
\end{tabular}




\subsection{PROGRAMMATIC WORK PRIORITY}

Double-shell tank 241-SY-101 poses the greatest safety hazard of the 25 tanks on the Flammable Gas Watch List because of the severity of its gas release events. Other Flammable Gas Watch List tanks include five double-shell tanks and nineteen single-shell tanks. The six double-shell tanks on the Flammable Gas Watch List are as follows: 101-SY, 103-SY, 103-AN, 104-AN, 105-AN, and 101-AW. The nineteen single-shell tanks on the Flammable Gas Watch List are as follows: 101-A, 101-AX, 103-AX, 102-S, 111-S, 112-S, 101-SX, 102-SX, 103-SX, 104-SX, 105-SX, 106-SX, 109-SX, 110-T, 103-U, 105-U, 107-U, 108-U, and 109-U; 103-AX and 109-SX have been interim stabilized. The hazard level of the other tanks is substantially less than that associated with 101-SY. Therefore these other Watch List tanks will probably not require in-situ mitigations; but they will be monitored and studied.

Double-shell tanks on the Flammable Gas Watch List appear to store waste that is similar to that in tank 241-SY-101; therefore they may all be hazardous to some extent. Furthermore, four of the double-shell tanks have periodic gas release events. The tanks that exhibit gas release events may require mitigation (e.g., pumping, heating, and dilution) prior to treatment. Waste in tank 241-SY-103 fills about 280 inches of the 400 inches available. Thus, tank 241-SY-103 could receive waste from 241-SY-101 if the dilution option for 241-SY-101 mitigation is ever used. If flammable gas issues associated with tanks 241-SY-101 and 241-SY-103 are addressed, the unreviewed safety question associated with the 241-SY Tank Farm is disposed of. Therefore, 241-SY-103 receives a priority ranking of two, behind 101-SY. Tank 101-AW exhibits a large pressure increase (almost one-inch water gauge) during gas release events, so it is ranked third among the double-shell tanks. Tanks 104-AN and 105-AN exhibit regular gas release events; tank 103-AN does not. Double-shell tanks are ranked in Table 5-1.

Table 5-1. Double-Shell Tank Ranking.

\begin{tabular}{|c|c|}
\hline Priority & Tark \\
\hline 1 & $101-\mathrm{SY}$ \\
\hline 2 & $103-\mathrm{SY}$ \\
\hline 3 & $101-\mathrm{AW}$ \\
\hline 4 & $104-\mathrm{AN}$ \\
\hline 5 & $105-\mathrm{AN}$ \\
\hline 6 & $103-\mathrm{AN}$ \\
\hline
\end{tabular}

Other considerations for double-shell tanks are given in Table 5-2. 
Table 5-2. Scoring Double-Shell Tanks for Work Prioritization.

\begin{tabular}{|l|c|c|c|c|c|}
\hline $\begin{array}{c}\text { Double-shell } \\
\text { tank }\end{array}$ & $\begin{array}{c}\text { Magntude of gas } \\
\text { release event }\end{array}$ & $\begin{array}{c}\text { Need for } \\
\text { mitigation }\end{array}$ & $\begin{array}{c}\text { Lack of head } \\
\text { space }\end{array}$ & reat load & Score \\
\hline $101-\mathrm{SY}$ & 1 & 1 & 2 & 1 & 5 \\
\hline $103-\mathrm{SY}$ & 4 & 2 & 6 & 6 & 18 \\
\hline $101-\mathrm{AW}$ & 3 & 3 & 3 & 5 & 15 \\
\hline $103-\mathrm{AN}$ & 5 & 4 & 5 & 3 & 17 \\
\hline $104-\mathrm{AN}$ & 2 & 3 & 4 & 2 & 13 \\
\hline $105-\mathrm{AN}$ & 2 & 3 & 1 & 4 & 13 \\
\hline
\end{tabular}

The single-shell tanks on the Flammable Gas Watch List do not appear to exhibit gas release events. Most of the tanks have a ratio of gas space to tank space approaching or exceeding one. These tanks will not require mitigation. Two single-shell tanks (103-AX and 109-AX) have already been interim stabilized. Tank 102-SX may have developed a leak, and tank 101-A has a ratio of gas space to tank space of only 0.25 ; therefore, these two tanks are top priorities for the single-shell tanks. Tanks 102-S and 106-SX are also on the Organic Watch List, and they are ranked next. Single-shell tank rankings are listed by Table 5-3; other considerations for scoring these tanks are given by Table 5-4. Finally, background information on Hanford tank from waste is provided by Table 5-5.

The work schedule for the Flammable Gas Tank Safety Program is given in Table 5-6. 
WHC-SD-WM-SD-019 Rev. 0

Table 5-3. Single-Shell Tank Ranking.

\begin{tabular}{|c|c|}
\hline Prionity & Tast \\
\hline 1 & $102-\mathrm{SX}$ \\
\hline 2 & $101-\mathrm{A}$ \\
\hline 3 & $102-\mathrm{S}$ \\
\hline 4 & $106-\mathrm{SX}$ \\
\hline 5 & $101-\mathrm{AX}$ \\
\hline 6 & $103-\mathrm{U}$ \\
\hline 7 & $111-\mathrm{S}$ \\
\hline 8 & $108-\mathrm{U}$ \\
\hline 9 & $109-\mathrm{U}$ \\
\hline 10 & $112-\mathrm{S}$ \\
\hline 11 & $105-\mathrm{U}$ \\
\hline 12 & $110-\mathrm{T}$ \\
\hline 13 & $105-\mathrm{SX}$ \\
\hline 14 & $103-\mathrm{SX}$ \\
\hline 15 & $101-\mathrm{SX}$ \\
\hline 16 & $104-\mathrm{SX}$ \\
\hline 17 & $109-\mathrm{SX}$ \\
\hline 18 & $103-\mathrm{AX}$ \\
\hline
\end{tabular}


WHC-SD-WM-SD-019 Rev. 0

Table 5-4. Scoring Single-Shell Tanks for Work Prioritization.

\begin{tabular}{|c|c|c|c|c|}
\hline 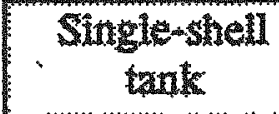 & $\begin{array}{c}\text { Tendency to leak } \\
\text { waste }\end{array}$ & $\begin{array}{l}\text { Lack of heat } \\
\text {-space }\end{array}$ & $\begin{array}{l}\text { Need for interiti } \\
\text { stabitization }\end{array}$ & Score \\
\hline $101-A$ & None & 1 & 4 & 5 \\
\hline $110-A X$ & None & 2 & 5 & 7 \\
\hline $103-A X$ & None & 18 & None & 18 \\
\hline $102-S$ & None & 7 & 1 & 8 \\
\hline $111-S$ & None & 8 & 2 & 10 \\
\hline $112-S$ & None & 12 & 3 & 15 \\
\hline $101-S X$ & None & 16 & 6 & 22 \\
\hline $102-S X$ & Yes & 15 & 11 & 26 \\
\hline 103-SX & None & 11 & 12 & 23 \\
\hline 104-SX & None & 13 & 13 & 26 \\
\hline 105-SX & None & 6 & 14 & 20 \\
\hline 106-SX & None & 14 & 15 & 29 \\
\hline $109-S X$ & None & 18 & None & 18 \\
\hline $110-\mathrm{T}$ & None & 10 & 10 & 20 \\
\hline $103-U$ & None & 3 & 6 & 9 \\
\hline $105-U$ & None & 9 & 7 & 16 \\
\hline $108-U$ & None & 4 & 8 & 12 \\
\hline $109-U$ & None & 5 & 9 & 14 \\
\hline
\end{tabular}




\begin{tabular}{|c|c|c|c|c|c|c|c|c|c|c|c|c|}
\hline \multicolumn{13}{|c|}{ SINGLE SHELL TANKS } \\
\hline Tank Farm & Tank & $\begin{array}{c}\text { Waste } \\
\text { Vol. } \\
\text { (Kgal) }\end{array}$ & $\begin{array}{c}\text { Sr Invtry. } \\
\text { (BQ) }\end{array}$ & $\begin{array}{c}\text { Cs Invtry. } \\
(\mathrm{Bq})\end{array}$ & $\begin{array}{l}\text { Misc. } \\
\text { Invtry. } \\
(\mathrm{Bq})\end{array}$ & $\begin{array}{l}\text { Inventory } \\
\text { (Bq) }\end{array}$ & $\begin{array}{l}\text { Inventory } \\
\text { (Ci) }\end{array}$ & $\begin{array}{c}\text { Power } \\
(\mathrm{kW})\end{array}$ & $\begin{array}{l}\text { NO3- } \\
\text { (M) }\end{array}$ & $\begin{array}{l}\text { Hydrogen } \\
\text { (ft } 3 / \text { day) }\end{array}$ & $\begin{array}{c}\text { Hydrogen } \\
\text { (\%LFL) }\end{array}$ & $\begin{array}{l}\text { TOC } \\
(g / 1)\end{array}$ \\
\hline $241-A$ & 101 & $9 \$ 3$ & $1.62 \mathrm{~T}+16$ & & & $1.625+6$ & 4,36 & 3,03 & 3,76 & I.t. & 2493 & 14 \\
\hline \multirow[t]{5}{*}{ (1 Mgal ea.) } & 102 & 41 & $1.00 \mathrm{E}+10$ & $7.02 \mathrm{E}+15$ & $3.72 \mathrm{E}+12$ & $7.02 \mathrm{E}+15$ & $1.90 \mathrm{E}+05$ & 0.93 & 2.08 & 0.52 & 2.06 & \\
\hline & 103 & 371 & $2.75 \mathrm{E}+15$ & $2.27 \mathrm{E}+16$ & $1.24 E+13$ & $2.55 \mathrm{E}+16$ & $6.88 \mathrm{E}+05$ & 3.53 & 2.46 & 1.75 & 9.51 & \\
\hline & 104 & 28 & $1.54 \mathrm{E}+17$ & $4.13 E+15$ & $6.63 \mathrm{E}+14$ & $1.59 \mathrm{E}+17$ & $4.29 \mathrm{E}+06$ & 29.37 & 2.82 & 13.14 & 50.23 & \\
\hline & 105 & 19 & $9.54 E+16$ & $3.56 \mathrm{E}+15$ & $9.57 \mathrm{E}+15$ & $1.09 \mathrm{E}+17$ & $2.93 E+06$ & 18.33 & - & & 0.00 & \\
\hline & 106 & 125 & $3.63 E+16$ & $2.72 E+15$ & $7.00 \mathrm{E}+13$ & $3.91 E+16$ & $1.06 \mathrm{E}+06$ & 7.15 & 1.87 & 4.33 & 18.23 & \\
\hline $241-A X$ & 101 & 248 & $4.662+14$ & $2.632+16$ & 1.56E+11 & $2.681+16$ & $723 E+05$ & 3.58 & 3.34 & 1.42 & 13.88 & II \\
\hline \multirow[t]{3}{*}{ (1 Mgal ea.) } & 102 & 39 & $7.14 \mathrm{E}+13$ & $1.47 \mathrm{E}+14$ & $4.80 \mathrm{E}+12$ & $2.23 E+14$ & $6.03 E+03$ & 0.03 & 3.70 & 0.01 & 0.05 & \\
\hline & 103 & 112 & $2,065+15$ & $6.37 \mathrm{E}+16$ & $286 \mathrm{E}+111$ & $6.581+16$ & $1.78 \mathrm{E}+06$ & 8.84 & 2.58 & 4.22 & 17.59 & 2.8 \\
\hline & 104 & 7 & $1.07 \mathrm{E}+17$ & $2.47 E+15$ & $1.23 E+16$ & $1.22 \mathrm{E}+17$ & $3.29 \mathrm{E}+06$ & 20.35 & 1.14 & 17.21 & 64.26 & \\
\hline $241-8$ & 101 & 113 & $3.61 \mathrm{E}+16$ & $9.67 \mathrm{E}+15$ & $1.67 \mathrm{E}+13$ & $4.58 \mathrm{E}+16$ & $1.24 \mathrm{E}+06$ & 8.04 & 22 & 5.27 & 37.76 & \\
\hline$(12 \bigcirc 0.53$ & 102 & 32 & $1.74 \mathrm{E}+13$ & $1.34 \mathrm{E}+14$ & $7.13 \mathrm{E}+09$ & $1.51 \mathrm{E}+14$ & $4.09 \mathrm{E}+03$ & 0.02 & 1.84 & 0.01 & 0.08 & \\
\hline Mgal ea. \& & 103 & 59 & $1.03 E+12$ & $3.82 E+14$ & $4.45 E+13$ & $4.28 \mathrm{E}+14$ & $1.16 \mathrm{E}+04$ & 0.05 & 1.06 & 0.05 & 0.30 & \\
\hline \multirow[t]{9}{*}{$4 @ 55 \mathrm{Kgal}$ ea.) } & 104 & 371 & $3.00 E+14$ & $1.90 \mathrm{E}+14$ & $3.00 \mathrm{E}+14$ & $7.90 \mathrm{E}+14$ & $2.14 \mathrm{E}+04$ & 0.08 & $=$ & & 0.00 & \\
\hline & 105 & 306 & $3.64 \mathrm{E}+13$ & $3.94 \mathrm{E}+12$ & $8.45 E+09$ & $4.03 \mathrm{E}+13$ & $1.09 \mathrm{E}+03$ & 0.01 & $=$ & & 0.00 & \\
\hline & 106 & 117 & $8.62 \mathrm{E}+12$ & $1.17 \mathrm{E}+14$ & $2.05 \mathrm{E}+09$ & $1.26 \mathrm{E}+14$ & $3.40 \mathrm{E}+03$ & 0.02 & 3.00 & 0.01 & 0.05 & \\
\hline & 107 & 165 & $5.75 E+14$ & $1.43 \mathrm{E}+14$ & $4.82 \mathrm{E}+14$ & $1.20 \mathrm{E}+15$ & $3.24 \mathrm{E}+04$ & 0.13 & $\overline{-}$ & & 0.00 & \\
\hline & 108 & 94 & $1.90 \mathrm{E}+15$ & $1.10 \mathrm{E}+15$ & $1.90 \mathrm{E}+15$ & $4.90 \mathrm{E}+15$ & $1.32 \mathrm{E}+05$ & 0.50 & - & & 0.00 & \\
\hline & 109 & 127 & $1.15 E+09$ & $3.38 \mathrm{E}+15$ & $3.58 \mathrm{E}+09$ & $3.38 \mathrm{E}+15$ & $9.14 \mathrm{E}+04$ & 0.45 & 2.48 & 0.22 & 1.64 & \\
\hline & 110 & 246 & $2.40 \mathrm{E}+15$ & $2.20 E+15$ & $2.40 E+15$ & $7.00 \mathrm{E}+15$ & $1.89 \mathrm{E}+05$ & 0.74 & - & & 0.00 & \\
\hline & 111 & 237 & $3.70 \mathrm{E}+06$ & $2.20 E+16$ & $3.70 \mathrm{E}+06$ & $2.20 \mathrm{E}+16$ & $5.95 \mathrm{E}+05$ & 2.92 & - & & 0.00 & \\
\hline & 112 & 33 & $3.70 \mathrm{E}+15$ & $7.40 E+15$ & $3.70 \mathrm{E}+15$ & $1.48 \mathrm{E}+16$ & $4.00 \mathrm{E}+05$ & 1.68 & - & & 0.00 & \\
\hline
\end{tabular}




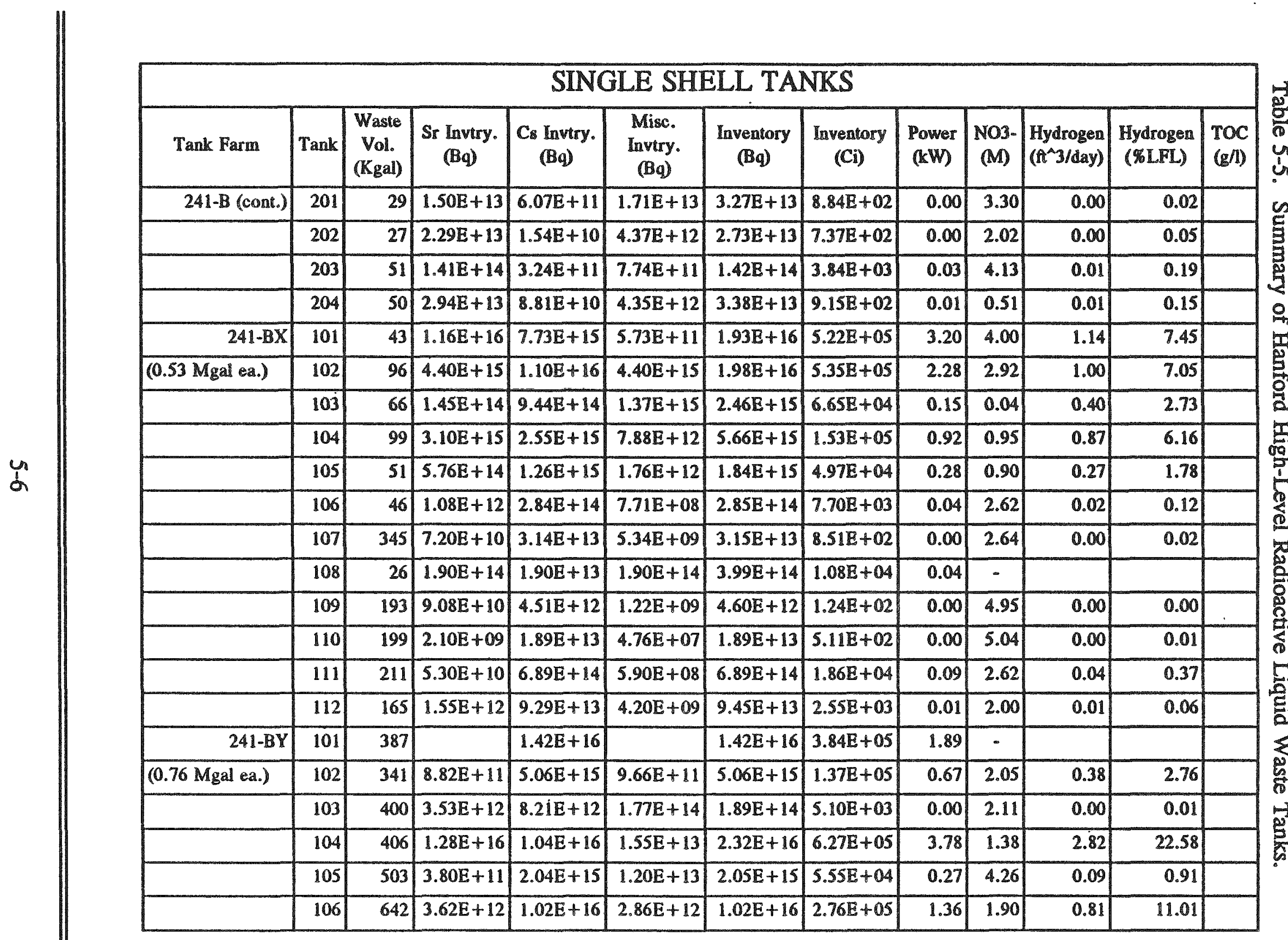




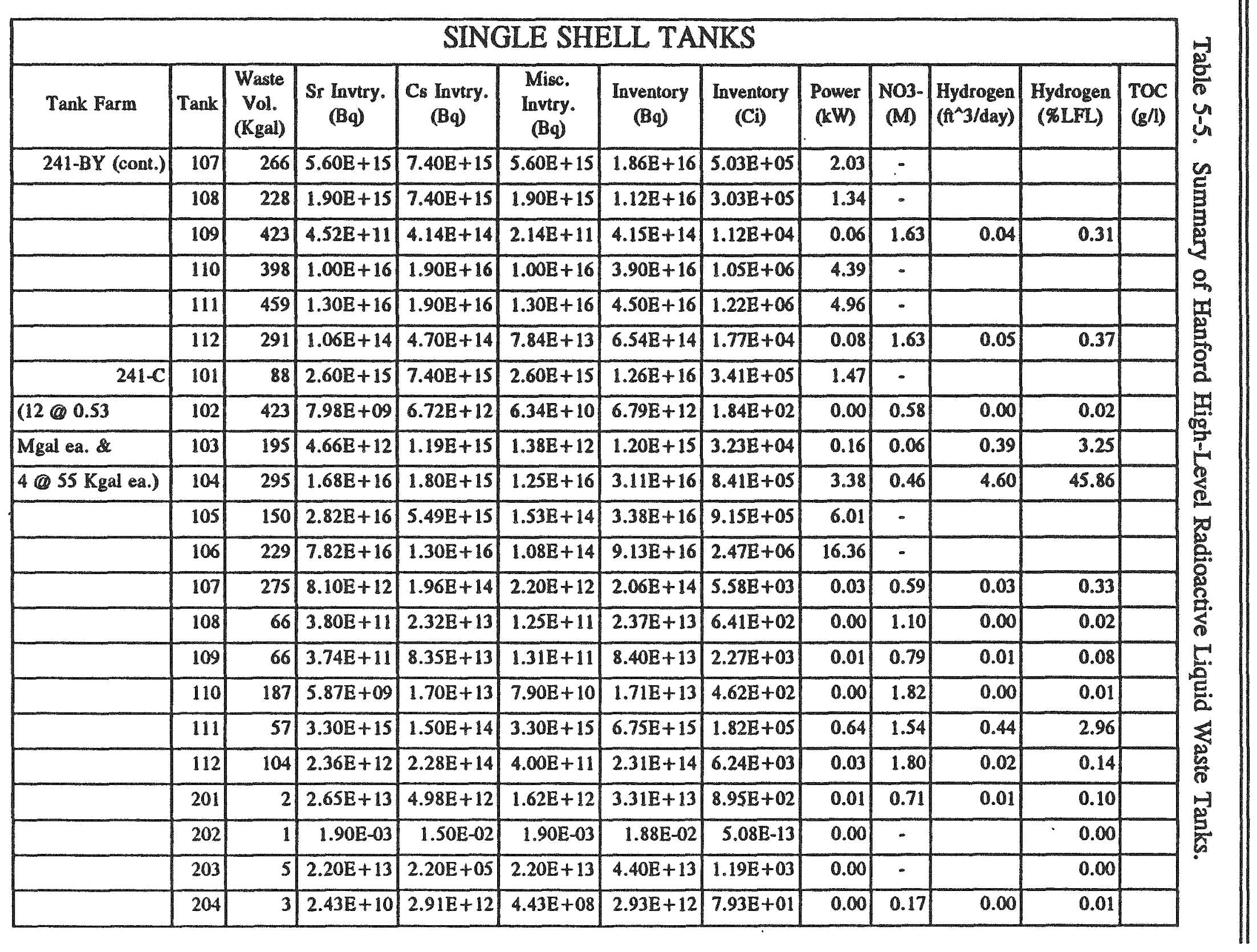




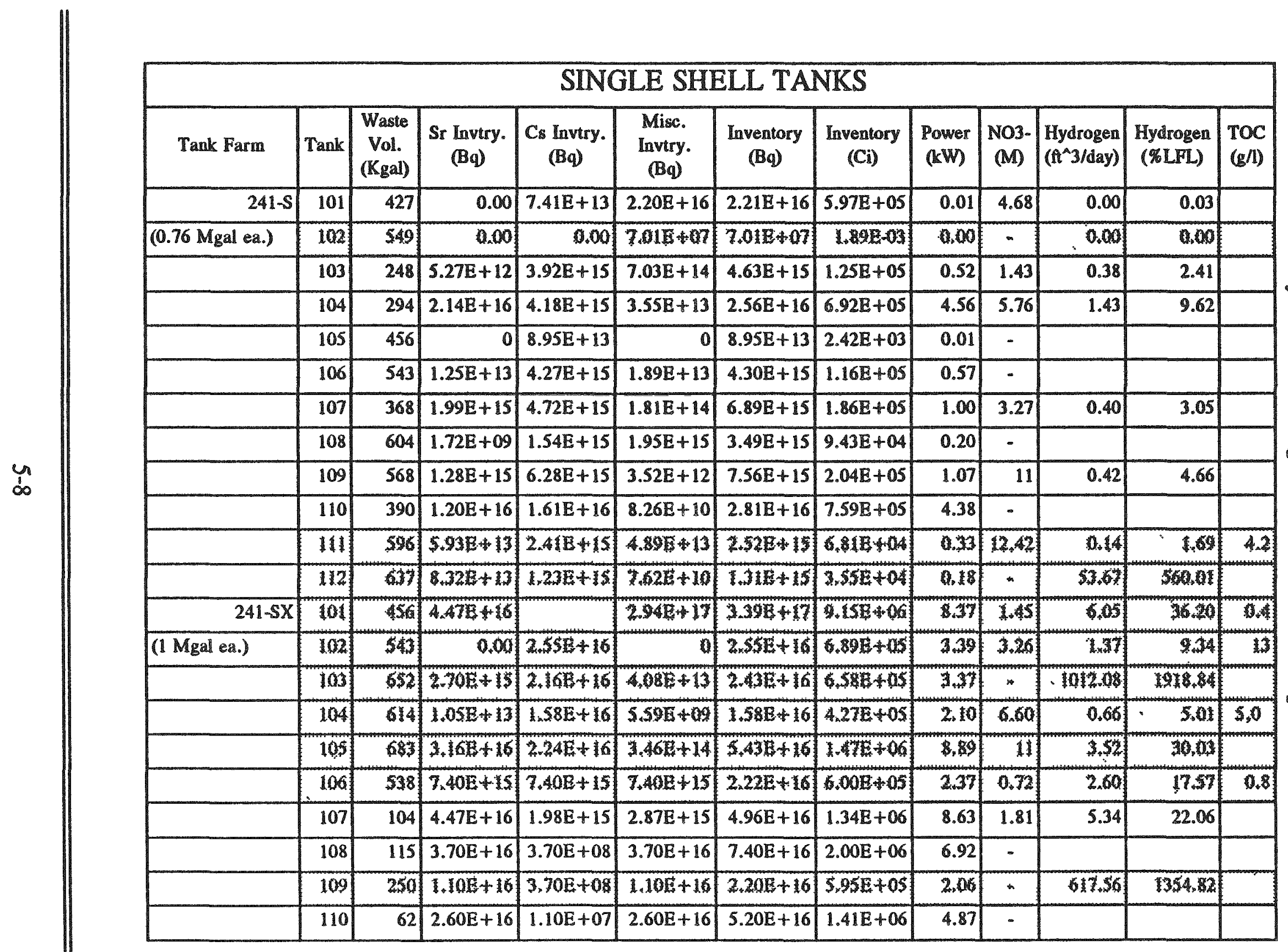




\begin{tabular}{|c|c|c|c|c|c|c|c|c|c|c|c|c|}
\hline \multicolumn{13}{|c|}{ SINGLE SHELL TANKS } \\
\hline Tank Farm & Tank & \begin{tabular}{|c|} 
Waste \\
Vol. \\
(Kgal)
\end{tabular} & $\begin{array}{c}\text { Sr Inviry. } \\
\text { (Bq) }\end{array}$ & $\begin{array}{c}\text { Cs Invtry. } \\
(\mathrm{Bq})\end{array}$ & $\begin{array}{l}\text { Misc. } \\
\text { Invtry. } \\
\text { (Bq) }\end{array}$ & $\begin{array}{l}\text { Inventory } \\
\text { (Bq) }\end{array}$ & $\begin{array}{l}\text { Inventory } \\
\text { (Ci) }\end{array}$ & $\begin{array}{c}\text { Power } \\
(\mathrm{kW})\end{array}$ & $\begin{array}{c}\text { NO3- } \\
\text { (M) }\end{array}$ & $\mid \begin{array}{l}\text { Hydrogen } \\
\left(\mathrm{At}^{\wedge} 3 / \text { day }\right)\end{array}$ & $\begin{array}{c}\text { Hydrogen } \\
\text { (\%LFL) }\end{array}$ & $\begin{array}{l}\text { TOC } \\
(\mathrm{g} / \mathrm{l})\end{array}$ \\
\hline $241-\mathrm{SX}$ (cont) & 111 & 125 & $5.92 \mathrm{E}+16$ & $3.77 \mathrm{E}+15$ & $1.41 E+12$ & $6.30 \mathrm{E}+16$ & $1.70 \mathrm{E}+06$ & 11.58 & 2.70 & 5.35 & 22.50 & \\
\hline & 112 & 92 & $3.70 \mathrm{E}+16$ & $1.10 \mathrm{E}+14$ & $3.70 \mathrm{E}+16$ & $7.41 \mathrm{E}+16$ & $2.00 \mathrm{E}+06$ & 6.94 & - & & & \\
\hline & 113 & 26 & $1.10 \mathrm{E}+16$ & $1.50 \mathrm{E}+16$ & $1.10 \mathrm{E}+16$ & $3.70 \mathrm{E}+16$ & $1.00 \mathrm{E}+06$ & 4.05 & - & & & \\
\hline & 114 & 181 & $3.70 E+16$ & $1.90 \mathrm{E}+01$ & $3.70 \mathrm{E}+16$ & $7.40 \mathrm{E}+16$ & $2.00 \mathrm{E}+06$ & 6.92 & - & & & \\
\hline & 115 & 12 & $7.61 \mathrm{E}+16$ & $1.56 \mathrm{E}+14$ & $7.38 \mathrm{E}+14$ & $7.70 \mathrm{E}+16$ & $2.08 \mathrm{E}+06$ & 14.26 & - & & & \\
\hline $241-T$ & 101 & 102 & $2.12 \mathrm{E}+11$ & $3.95 \mathrm{E}+14$ & $4.50 \mathrm{E}+11$ & $3.96 \mathrm{E}+14$ & $1.07 \mathrm{E}+04$ & 0.05 & 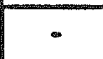 & & 0.00 & \\
\hline$(12 \bigcirc 0.53$ & 102 & 32 & $1.50 \mathrm{E}+12$ & $1.50 \mathrm{E}+13$ & $1.50 \mathrm{E}+12$ & $1.80 \mathrm{E}+13$ & $4.86 E+02$ & 0.00 & 2.18 & 0.00 & 0.02 & \\
\hline Mgal ea. \& & 103 & 27 & $1.50 \mathrm{E}+12$ & $1.50 \mathrm{E}+13$ & $1.50 E+12$ & $1.80 E+13$ & $4.86 E+02$ & 0.00 & 1.31 & 0.00 & 0.03 & \\
\hline $4 \bigcirc 55 \mathrm{Kgal} \mathrm{ea.)}$ & 104 & 445 & $4.43 E+14$ & $1.14 \mathbb{E}+14$ & $2.19 \mathbb{E}+13$ & $5.79 \mathrm{E}+14$ & $1.56 \mathrm{E}+04$ & 0.10 & 1.45 & 0.07 & 1.07 & \\
\hline & 105 & 98 & 0.00 & $5.02 E+13$ & $2.24 E+13$ & $7.26 \mathrm{E}+13$ & $1.96 \mathrm{E}+03$ & 0.01 & 1.57 & 0.00 & 0.03 & \\
\hline & 106 & 21 & $2.31 E+15$ & $1.92 E+15$ & $1.93 \mathrm{E}+15$ & $6.16 \mathrm{E}+15$ & $1.66 \mathrm{E}+05$ & 0.69 & 24 & 0.48 & 8.61 & \\
\hline & 107 & 180 & $4.17 \mathbb{E}+11$ & $2.81 E+13$ & $1.51 E+10$ & $2.85 \mathrm{E}+13$ & $7.71 E+02$ & 0.00 & 2.19 & 0.00 & 0.02 & \\
\hline & 108 & 44 & 0.00 & $7.72 E+14$ & $1.10 \mathrm{E}+10$ & $7.72 \mathrm{E}+14$ & $2.09 E+04$ & 0.10 & 0.80 & 0.11 & 2.11 & \\
\hline & 109 & 58 & $2.60 E+12$ & $1.90 \mathrm{E}+14$ & $2.60 E+12$ & $1.95 \mathrm{E}+14$ & $5.28 \mathrm{E}+03$ & 0.03 & 0.98 & 0.02 & 0.16 & \\
\hline & 110 & 379 & $1.50 \mathrm{E}+14$ & $7.400+03$ & $1,50 \mathrm{E}+1 \mathrm{~A}$ & $3.00 \mathrm{E}+14$ & $8 .+18+03$ & 0.03 & 0.91 & 0,03 & 0.94 & \\
\hline & 111 & 458 & 0 & $1.32 E+13$ & $1.79 \mathrm{E}+13$ & $3.11 E+13$ & $8.41 \mathrm{E}+02$ & 0.00 & - & & & \\
\hline & 112 & 67 & & & $1.81 \mathbb{E}+09$ & $1.81 \mathrm{E}+09$ & $4.89 \mathrm{E}-02$ & 0.00 & 0.4 & 0.00 & 0.00 & \\
\hline & 201 & 29 & - & 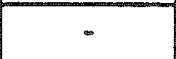 & 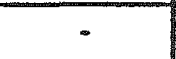 & 0.00 & 0.00 & & - & & & \\
\hline & 202 & 21 & - & - & - & 0.00 & 0.00 & & - & & & \\
\hline & 203 & 35 & - & - & - & 0.00 & 0.00 & & - & & & \\
\hline & 204 & 38 & $1.29 \mathrm{E}+12$ & $6.05 E+11$ & $7.00 E+10$ & $1.97 \mathrm{E}+12$ & $5.31 E+01$ & 0.00 & 0.91 & 0.00 & 0.01 & \\
\hline
\end{tabular}




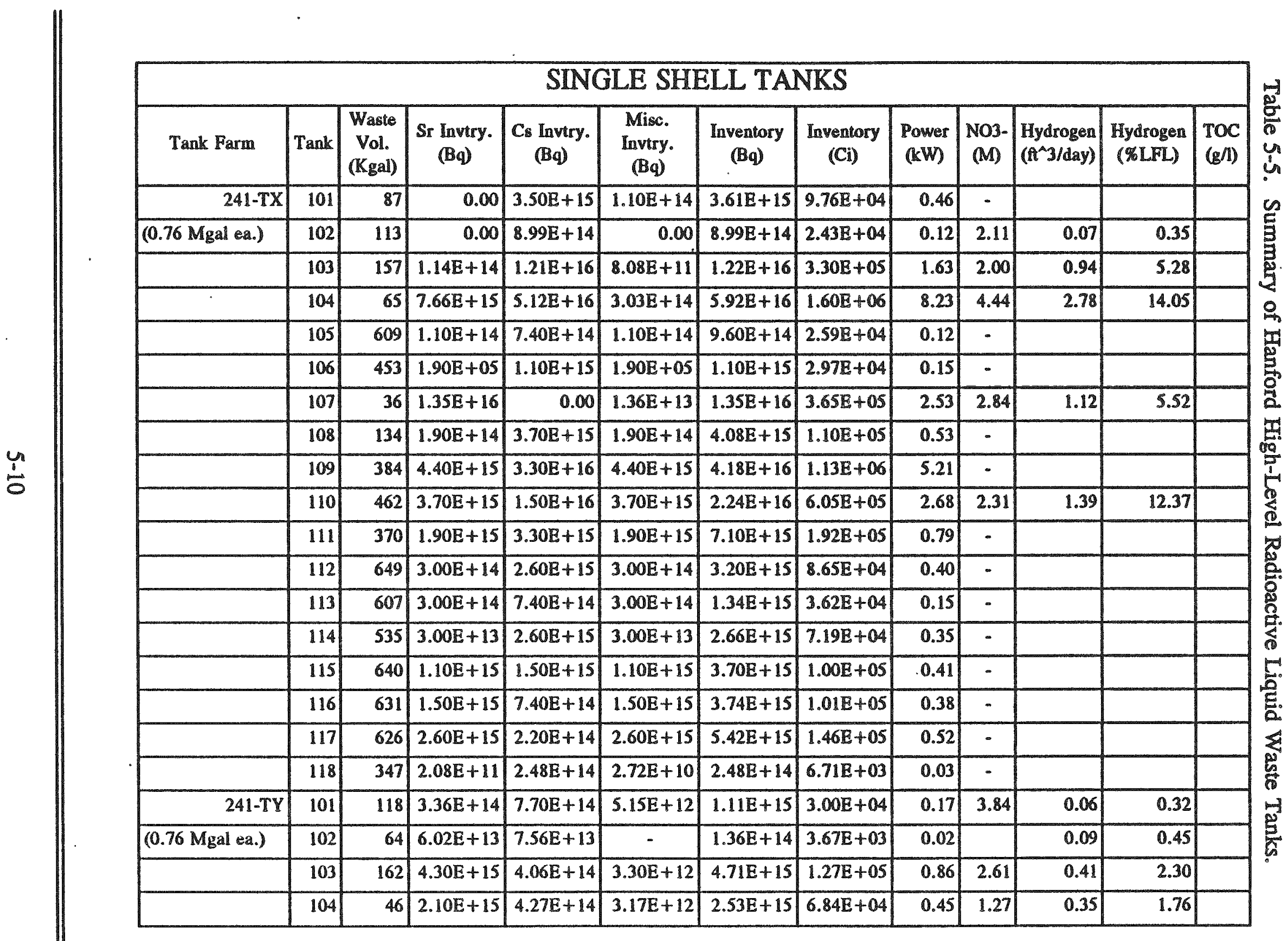




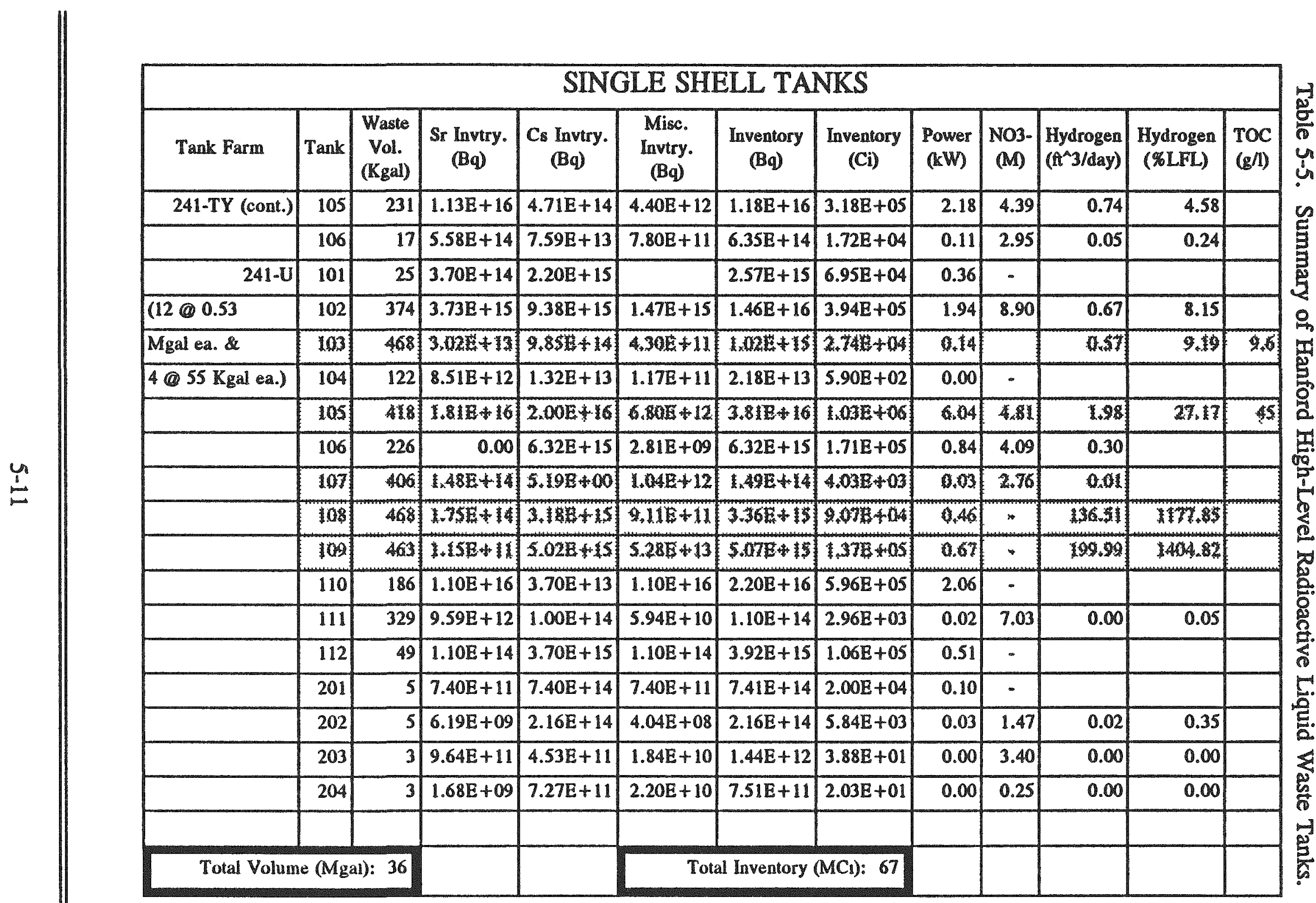

Shading $=$ Flammable Watch List Tanks 


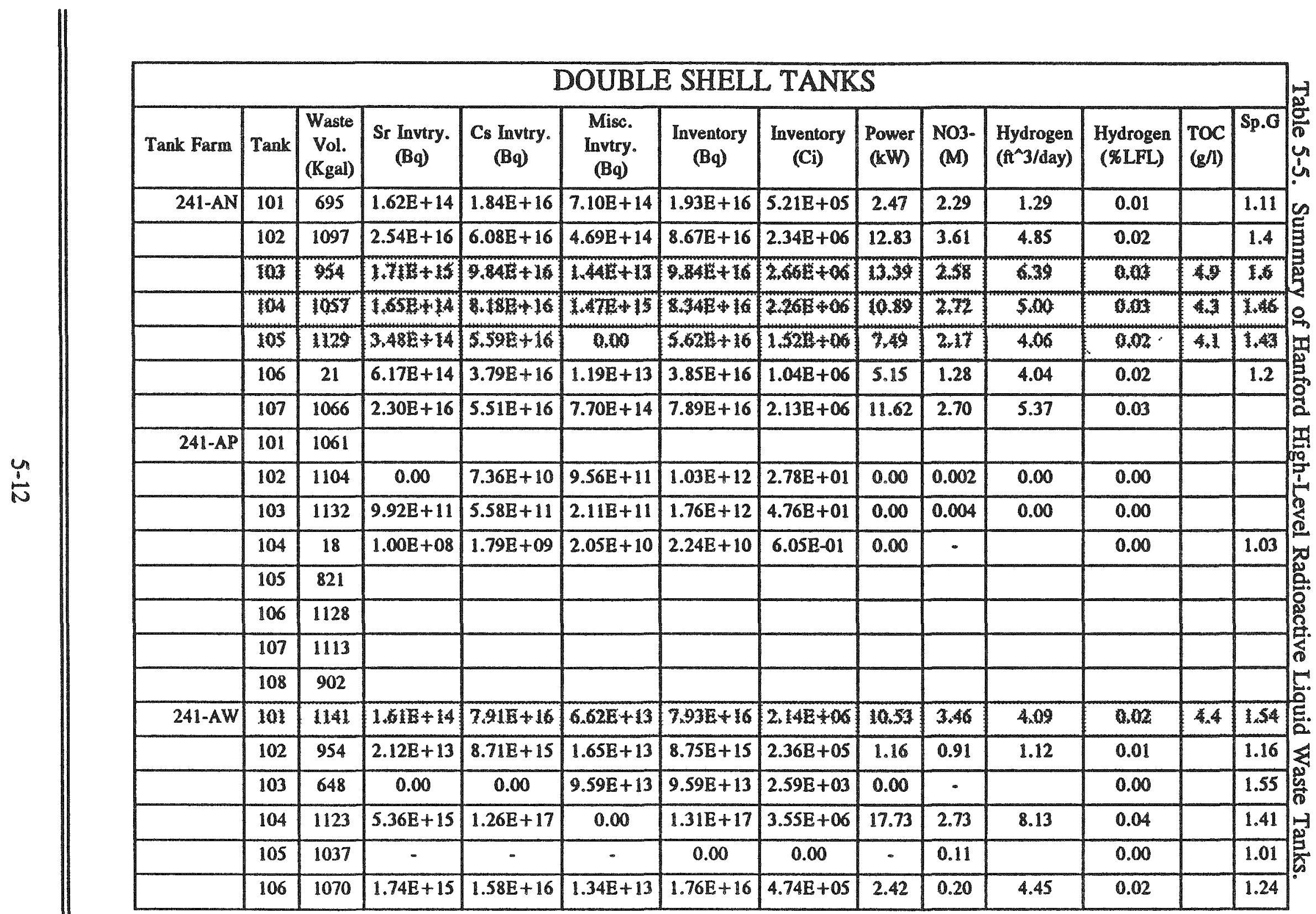




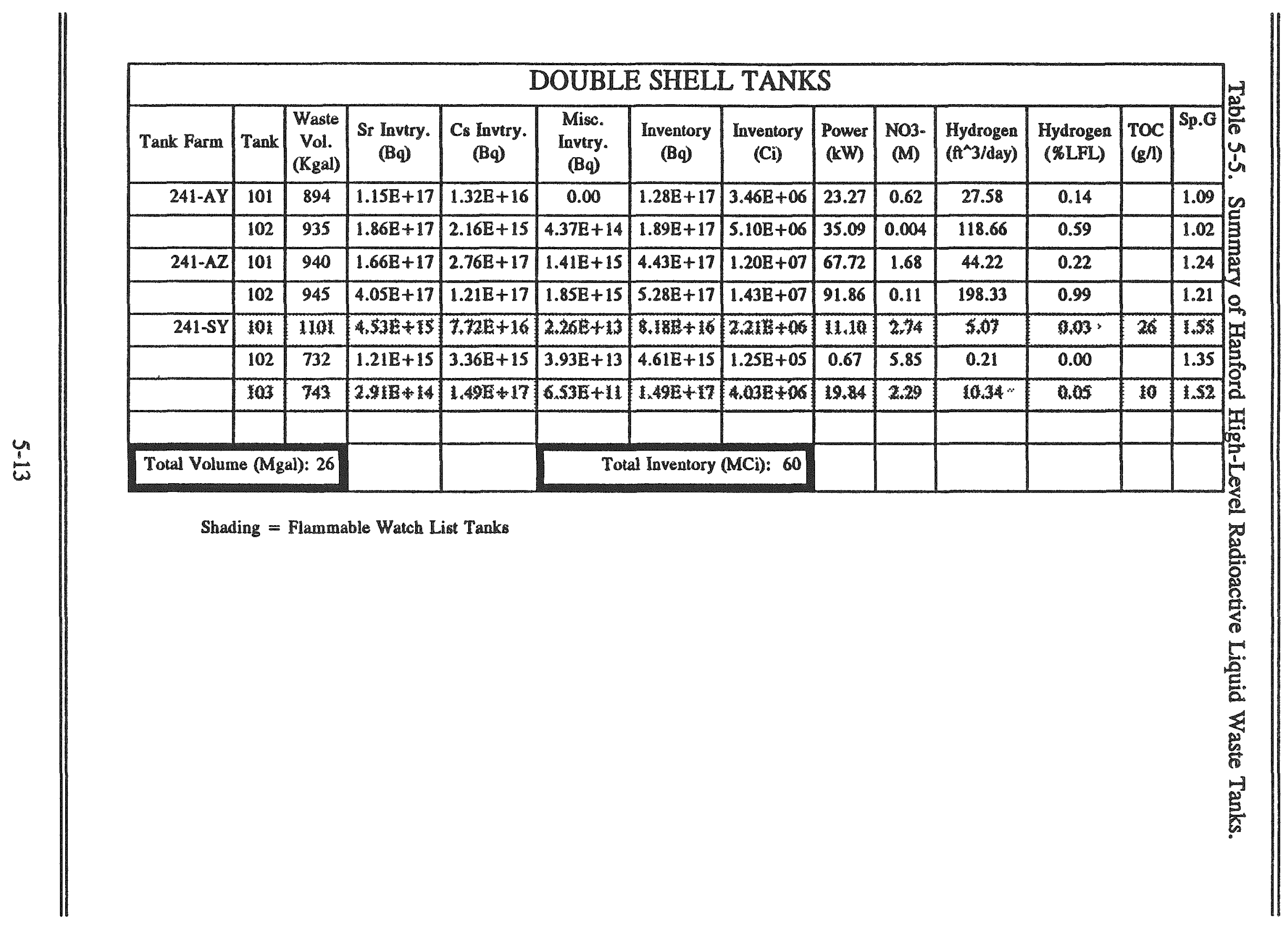




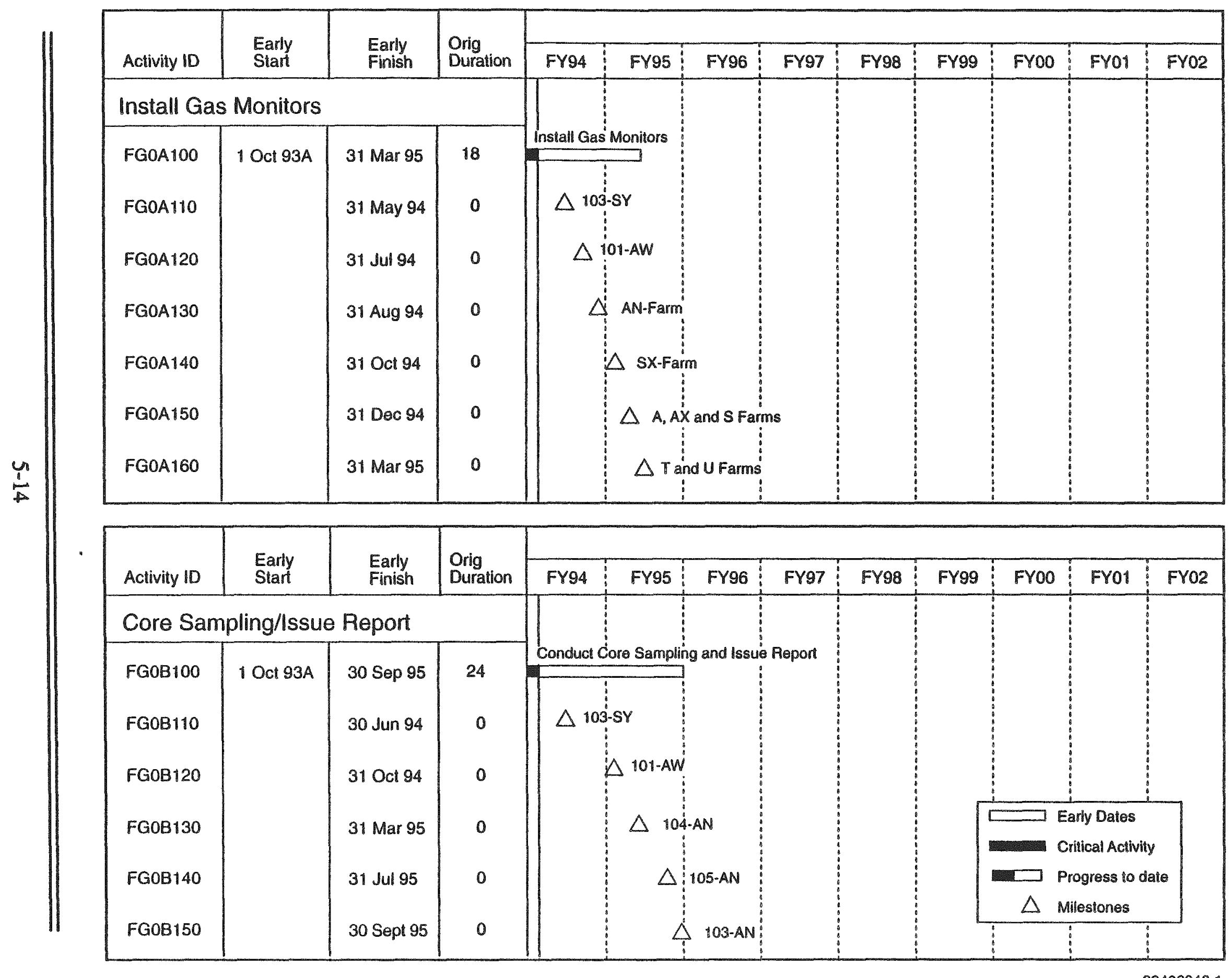




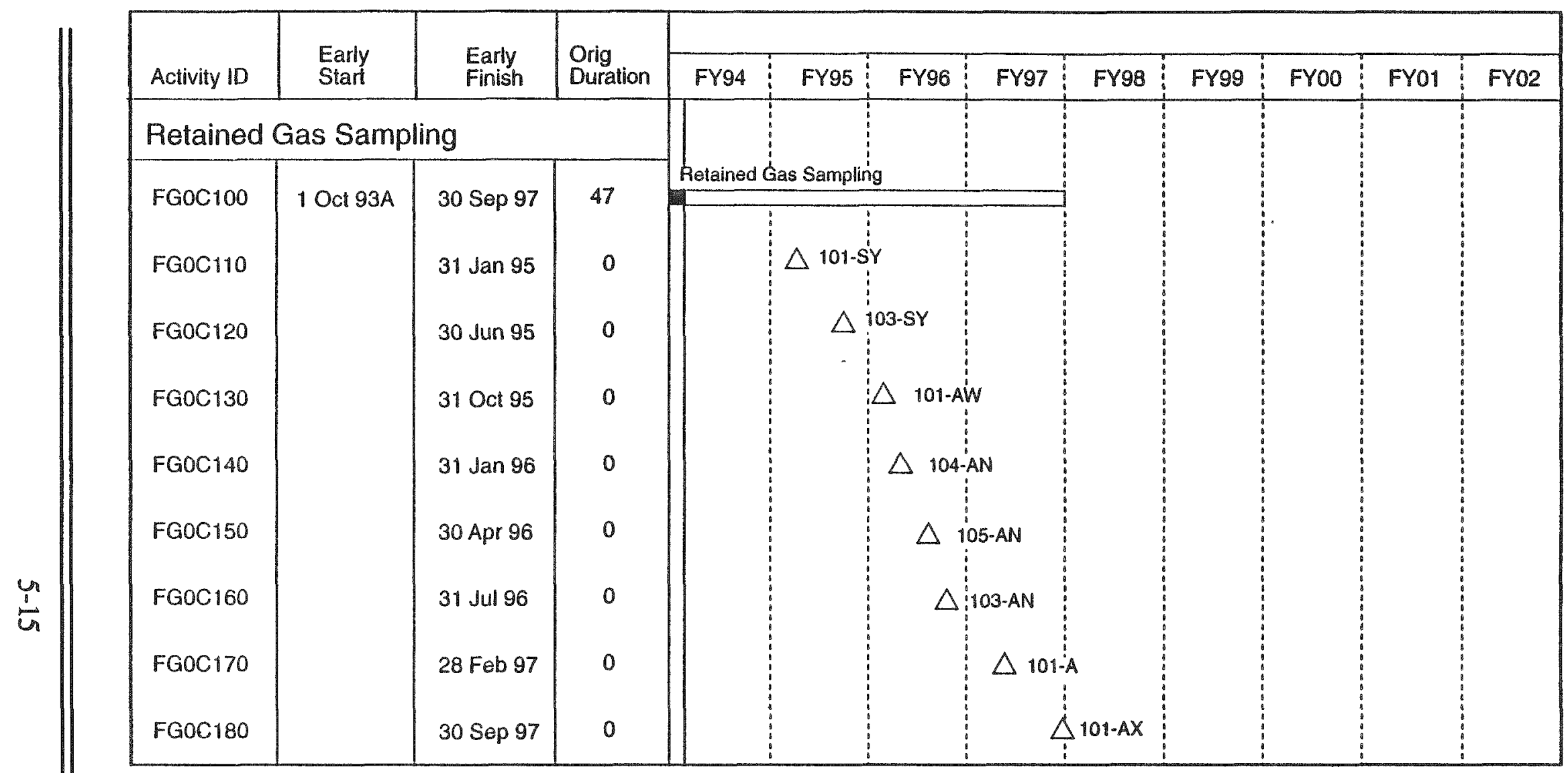

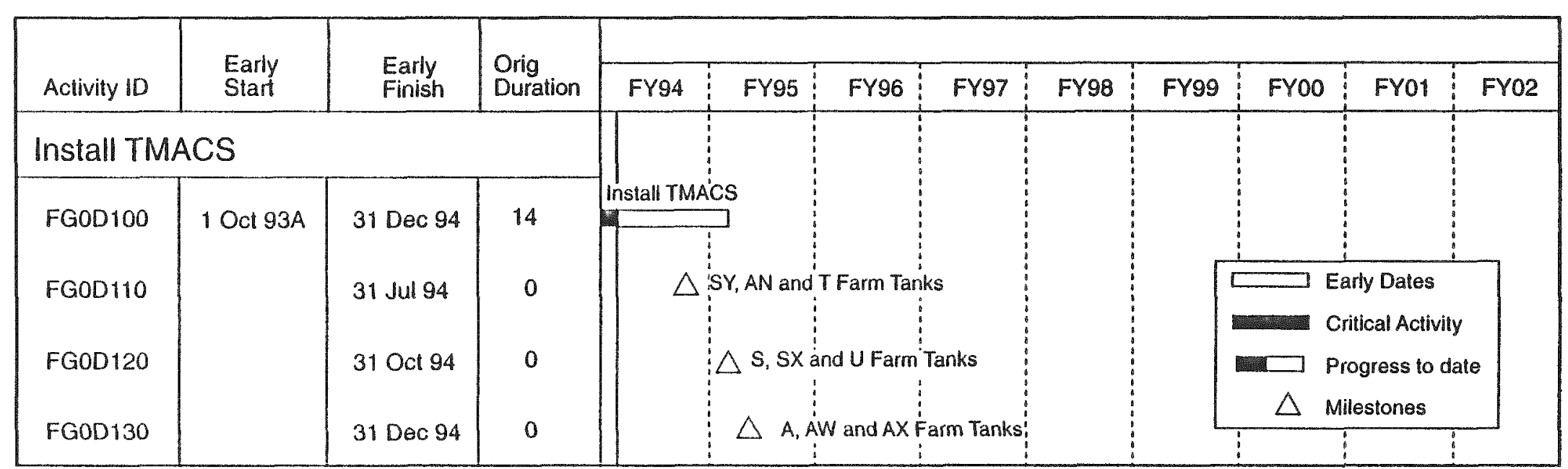

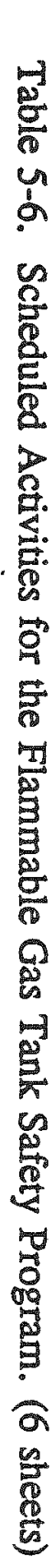




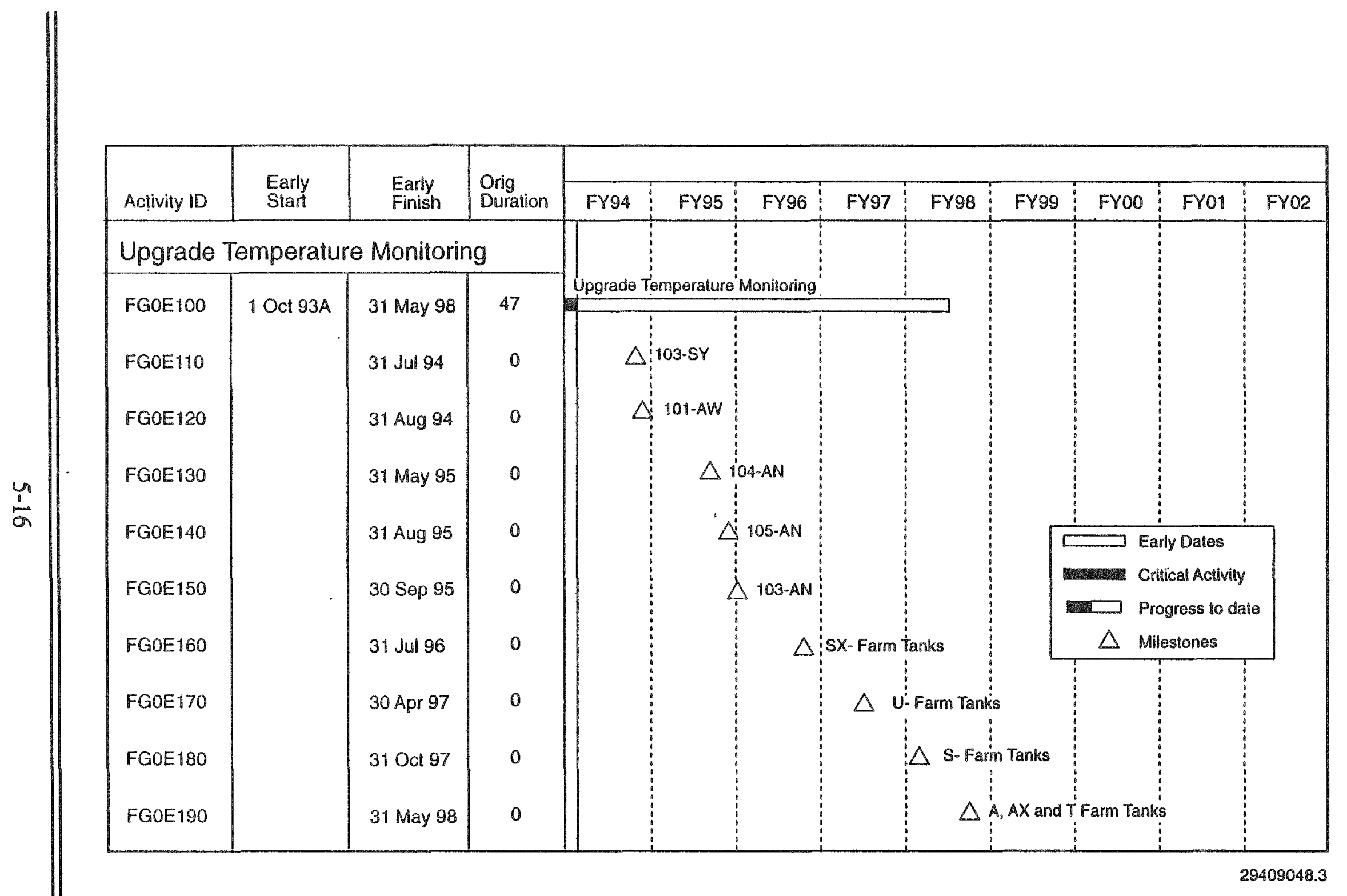




\subsection{WORK ACTIVITTES}

The safety issue exists because of the potential for tank waste to release flammable gas mixtures (primarily hydrogen and nitrous oxide) in concentrations exceeding the lower flammability limit (4 volume percent $\mathrm{H}_{2}$ ). Initial activities of the Flammable Gas Tank Safety Program have been directed at tank 241-SY-101 because this potential is realized. Work has focused on understanding the cyclic venting of flammable gases from tank 241-SY101 which has required analyses of core samples, laboratory studies, modeling studies, tank upgrades, developing mitigation alternatives, and a mitigation test using a mixer pump. Major accomplishments are listed below.

- A mixer pump was modified, installed, and successfully operated in tank 241-SY-101. The following ancillary equipment necessary to support the mitigation test was installed: a data acquisition and control system, multifunction instrument tree, and standard hydrogen monitors. Four air lances and a bent thermocouple tree were removed from the tank.

- Waste sample analysis results are documented in reports on waste chemistry and physical properties.

- A Bureau of Mines study on the flammability of gas mixtures was issued.

- Accident consequence criteria and requirements for resolution of the flammable gas safety issue were documented.

- Methods were developed to analyze tank 241-SY-101 waste for chelating agents and to qualitatively identify low molecular weight degradation products.

- A high-sensitivity mass spectrometer was installed and placed into routine operation at the Pacific Northwest Laboratory. Accurate analysis of gas samples from the vapor space of tank 101-SY are being obtained.

- A hazards assessment for tank 241-SY-101 was completed.

Near-term plans include the following major activities:

- Continuing mixer pump tests in tank 241-SY-101

- Developing heating, dilution and sonic mitigation methods

- Completing upgrades to the 241-SY Farm ventilation system

- Installing gas monitors on all Flammable Gas Watch List tanks

- Core sampling of double-shell tanks 241-SY-103 and 241-AW-101. 
The following types of work will be performed for the Hanford tank farms in order to resolve the flammable gas safety issue:

- Standard Hydrogen Monitoring Systems will be placed on all tanks.

- Crust auger sampling is required for Tanks 241-SY-103 and 241-AW-101 in fiscal year 1994. It is assumed that samples in future fiscal years will be obtained with the rotary mode sampling truck, and that auger sampling will not be needed. Core sampling is required for the double-shell tanks but not for the single-shell tanks.

- Data Quality Objectives are required for all tank sampling activities.

- Development of an evaluation method for the gas content of tank waste is required. All double-shell tanks will be sampled for retained gases.

- Ventilation upgrades (modular exhausters, inlet filter, instrumentation, and data acquisition and control systems) are required for the 241-AW, 241-SY and 241-AN Tank Farms. One portable exhauster will be prepared for use with single-shell tanks.

- One multi-function instrument tree is required for each tank to provide continuous temperature and pressure monitoring for each tank. All multifunction instrument trees and Standard Hydrogen Monitoring Systems will be connected to the Tank Monitor and Control System.

- Television cameras are required to monitor work activities in double-shell tanks. One television system will be developed for use in single-shell tanks.

- Improved surface-level measurement capability is required for all tanks.

- Electrical upgrades may be required in the tank farms. Riser modifications and other minor upgrades may also be required.

- Work activities may require removal and legal disposal of minor equipment (sludge weights and surface level gauges) from tanks.

- Resolution of the unreviewed safety question will be done for the 241-SY Tank Farm first, then the remaining tanks. Safety documents will be incorporated into the Interim Safety Basis. 
- Resolution of the safety issue requires characterization of tank waste and therefore, installation of Standard Hydrogen Monitoring Systems, multifunction instrument trees, and improved surface level devices. All six double-shell tanks will be retrieved, and two double-shell tanks may require organic destruction. Although none of the single-shell tanks will be retrieved for resolution of the safety issue, they may need to be retrieved for Interim Stabilization.

- The mixer pump mitigation option in tank 241-SY-101 will work if any other tanks need mitigation.

- A new mitigation pump for tank 241-SY-101 will be designed, modified, and available for installation in fiscal year 1995.

Specific work activities for the Flammable Gas Tank Safety Program are shown in Table 6-1. 
Table 6-1. Work Activities for the Flammable Gas Tank Safety Program.

\begin{tabular}{|c|c|c|c|c|c|c|c|c|c|}
\hline \multirow{2}{*}{ MORK JOB } & \multirow{2}{*}{ PEDO } & \multicolumn{6}{|c|}{ 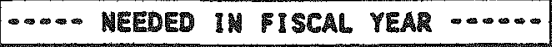 } & \multirow{2}{*}{$\begin{array}{c}\text { JOS } \\
\text { COMPLETE }\end{array}$} & \multirow{2}{*}{ COMMENTS } \\
\hline & & 94 & 95 & 96 & 97 & 98 & 99 & & \\
\hline \multicolumn{10}{|c|}{ 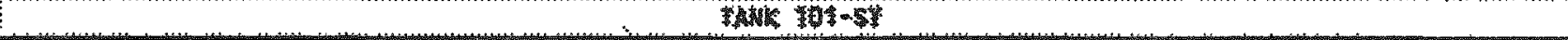 } \\
\hline \multicolumn{10}{|l|}{ Tsol03 Evaluste Define } \\
\hline Auger Sampl ing/Analys is & $Y$ & & & & & & & $Y$ & \\
\hline Core Sampling/Analysis (M4) & $\gamma$ & & & & & & & $\gamma$ & \\
\hline Data interpretation & $\gamma$ & & & & & & & $Y$ & \\
\hline Vapor sempling & $Y$ & & & & & & & $\vartheta$ & \\
\hline Vapor Analysis W/MSMS (PML) & $Y$ & $x$ & & & & & & & \\
\hline Window Work & $Y$ & & & & & & & $Y$ & see also mitigation \\
\hline GRE Meports & $Y$ & $x$ & & & & & & & \\
\hline Gas Analysis Reports & $Y$ & & & & & & & $Y$ & \\
\hline In-situ Gas Sampling & 的 & & & & & & & & dev under 104-AM \\
\hline Haste Behar Daca Eval (PNC) & $\gamma$ & $x$ & & & & & & & \\
\hline \multicolumn{10}{|l|}{ Is0105 Technology for Eval } \\
\hline Radiolytic Mechanisms (AML) & Y & & & & & & & $Y$ & \\
\hline Chemical Mech (GIT/Other) & 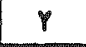 & & & & & & & $Y$ & \\
\hline Gas Generation (HMC/TBO) & $Y$ & & & & & & & $Y$ & \\
\hline Synthetic studies (PML) & $Y$ & & & & & & & $\gamma$ & \\
\hline org Methods Dev (PNL) & $Y$ & & & & & & & H & continue under 103-SY \\
\hline Start-Up New HSMS (PNL) & $Y$ & & & & & & & $Y$ & \\
\hline DeV Methods for HSMS (PML) & $\gamma$ & & & & & & & $\gamma$ & \\
\hline Physical Prop Methods Dev & 1 & & & & & & & & dev under 103-sy \\
\hline Physical Modeling (PNL) & $Y$ & & & & & & & $Y$ & \\
\hline Gas Plow Modeling & $Y$ & & & & & & & $Y$ & see also mitigation \\
\hline Thermal Behavior & $\varphi$ & $x$ & & & & & & & \\
\hline \multicolumn{10}{|l|}{ TS0133 Close USa/Resolve SI } \\
\hline Tech suppt USQ/WL Screening & $Y$ & $x$ & & & & & & & \\
\hline Use Databese Report & $Y$ & $x$ & & & & & & & \\
\hline Hazard Assessment & $Y$ & & & & & & & $Y$ & \\
\hline Safety Documentation & $Y$ & & & & & & & $Y$ & \\
\hline EAs & $Y$ & & & & & & & $\gamma$ & \\
\hline Hydrogen Burn Analysis & $Y$ & & & & & & & $Y$ & \\
\hline Is8/Close uso & $\varphi$ & $x$ & $x$ & & & & & & for st farm \\
\hline Si Resolution & $\gamma$ & & & & & & & & after Retrieval/IPM (9/01) \\
\hline \multicolumn{10}{|l|}{ Ts0121 Monitoring Upgrades } \\
\hline Riser/Mindow Planning & $\varphi$ & & & & & & & $Y$ & \\
\hline Gas Monitoring (SHMS) & $Y$ & & & & & & & Y & \\
\hline Repair Existing TCs & $Y$ & & & & & & & $Y$ & \\
\hline MITs & $Y$ & & & & & & & $Y$ & \\
\hline TMACS & $Y$ & & & & & & & $\gamma$ & \\
\hline Surface Level & $Y$ & & & & & & & $Y$ & \\
\hline TV Camera & $\gamma$ & & & & & & & $Y$ & \\
\hline Vertilation & $Y$ & $x$ & & & & & & & \\
\hline Permitting/NEPA & $\mathbf{Y}$ & $x$ & & & & & & & \\
\hline
\end{tabular}


Table 6-1. Work Activities for the Flammable Gas Tank Safety Program.

\begin{tabular}{|c|c|c|c|c|c|c|c|c|c|}
\hline \multirow{2}{*}{ HORK JOB } & \multirow{2}{*}{ REOO } & \multicolumn{6}{|c|}{ 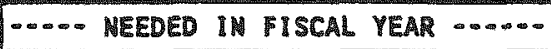 } & \multirow{2}{*}{$\begin{array}{c}\text { JOB } \\
\text { COAPLETE }\end{array}$} & \multirow{2}{*}{ COMHEMTS } \\
\hline & & 94 & 85 & 96 & 97 & 98 & 99 & & \\
\hline Dens ity Trees & M & & & & & & & & VOTTs by Mitigation \\
\hline Lightning Protection & M & & & & & & & $y$ & removed: not reqd \\
\hline Misc Tf Upgrades & $\gamma$ & & & & & & & $Y$ & \\
\hline Equip Removl/o ispos//storage & $Y$ & & & & & & & 1 & \\
\hline \multicolumn{10}{|l|}{ Ts0122 Mitigation } \\
\hline Technology Dev/Model ing & $\gamma$ & $x$ & & & & & & & \\
\hline Mitigation Test & $\gamma$ & $x$ & & & & & & & \\
\hline Design & $Y$ & $x$ & & & & & & & \\
\hline SA/EA & $\gamma$ & $x$ & & & & & & & \\
\hline Procure/fab & $\gamma$ & $x$ & $x$ & & & & & & \\
\hline Window Work/Install & $\gamma$ & & $x$ & & & & & & \\
\hline \multicolumn{10}{|c|}{ 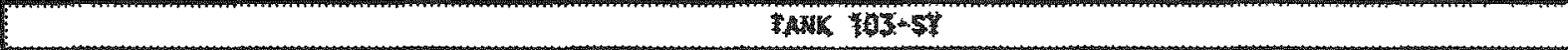 } \\
\hline \multicolumn{10}{|l|}{ Ts0103 Evaluate \& Define } \\
\hline Auger sampling/Analys is & $\gamma$ & $x$ & & & & & & & \\
\hline Core sampling/Analysis (ML) & $\gamma$ & $x$ & $x$ & & & & & & \\
\hline Data Interpretation & $\gamma$ & & $x$ & & & & & & \\
\hline Vapor Sampling & $\gamma$ & $x$ & & & & & & & \\
\hline Vapor Analysis w/HSMS (PML) & $\varphi$ & $x$ & $x$ & & & & & & \\
\hline Window Work & $\gamma$ & $x$ & $x$ & & & & & & see also Mitigation \\
\hline GRE Reports & $Y$ & $x$ & $x$ & & & & & & \\
\hline Gas Analysis Reports & $Y$ & $x$ & $x$ & & & & & & \\
\hline In-situ Gas Sampling & M & & & & & & & & dev under 104-AM \\
\hline Waste Behav Data Eval (PML) & $\gamma$ & $x$ & $x$ & & & & & & \\
\hline \multicolumn{10}{|l|}{ Ts0105 Technology for EVal } \\
\hline Radiolyeic Mechanisms (ANL) & 1 & & & & & & & & done under 101-5Y \\
\hline Chemical Mech (GIT/Other) & $Y$ & $x$ & $x$ & & & & & & \\
\hline Gas Generation (WHC/TBD) & $\gamma$ & $x$ & $x$ & & & & & & \\
\hline Symthetic studies (PML) & $\gamma$ & $x$ & $x$ & & & & & & \\
\hline Org Methods Dev (PML) & $y$ & $x$ & $x$ & & & & & & \\
\hline start-Up Mew HSMS (PML) & W & & & & & & & & done under $101.5 Y$ \\
\hline Dev Methods for HSMS (PML) & * & & & & & & & & done under $101-5 Y$ \\
\hline Physical Prop Methods Dev & $Y$ & & $x$ & & & & & & \\
\hline Physical Modeling (PNL) & $\gamma$ & $x$ & $x$ & & & & & & \\
\hline Gas Flow Model ing & $\gamma$ & & $x$ & & & & & & see also Mitigation \\
\hline Thermal sehavior & $\varphi$ & $x$ & $x$ & & & & & & \\
\hline \multicolumn{10}{|l|}{ Tso133 Close USA/Resolve SI } \\
\hline Tech Suppt USQ/WL Screening & $\gamma$ & $x$ & & & & & & & \\
\hline USa Database Report & $Y$ & $x$ & & & & & & & \\
\hline Hazard Assessment & $Y$ & & & & & & & & \\
\hline Safery Documentation & $\bar{r}$ & $\bar{x}$ & & & & & & & \\
\hline EAs & $Y$ & $x$ & & & & & & & \\
\hline Hydrogen Bum Analysis & $Y$ & $x$ & & & & & & & \\
\hline Ise/close Usa & $\varphi$ & & $x$ & & & & & & \\
\hline
\end{tabular}


Table 6-1. Work Activities for the Flammable Gas Tank Safety Program.

\begin{tabular}{|c|c|c|c|c|c|c|c|c|c|}
\hline \multirow{2}{*}{ WORK JOS } & \multirow{2}{*}{ REOO } & \multicolumn{6}{|c|}{ 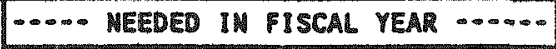 } & \multirow{2}{*}{$\begin{array}{c}\text { JOS } \\
\text { COMPLETE }\end{array}$} & \multirow{2}{*}{ COAMENTS } \\
\hline & & 94 & 95 & 96 & 97 & 98 & 99 & & \\
\hline S1 Resolution & $\varphi$ & & & & & & & & after Retrieval/IPM (9/01) \\
\hline \multicolumn{10}{|l|}{ TS0121 Monitoring Upgrades } \\
\hline Riser/Window Planning & $Y$ & $x$ & & & & & & & \\
\hline Gas Monitoring (SHMS) & $Y$ & & & & & & & $Y$ & \\
\hline Repoir Existing TCs & $Y$ & & & & & & & $Y$ & \\
\hline MITS & $Y$ & $x$ & & & & & & & \\
\hline TMACS & $y$ & & & & & & & $Y$ & \\
\hline Surface Level & $Y$ & $x$ & & & & & & & \\
\hline TV Canera & $Y$ & $x$ & & & & & & & \\
\hline Ventilation & $Y$ & $x$ & & & & & & & \\
\hline Permitting/NEPA & $\gamma$ & $x$ & & & & & & & \\
\hline Density Trees & $Y$ & & $x$ & $x$ & & & & & if required \\
\hline Lightning Protection & H & & & & & & & & \\
\hline Misc Tf Upgrades & $Y$ & & $x$ & & & & & & \\
\hline Equip Removl/o isposl/storage & $Y$ & & $x$ & & & & & & \\
\hline \multicolumn{10}{|l|}{ Ts0122 Mitigation } \\
\hline Technology Dev/Model ing & H & & & & & & & & done under 101-51 \\
\hline Mitigation Test & 4 & & & & & & & & done under 101-5y \\
\hline Design & $\gamma$ & $x$ & & & & & & & \\
\hline SA/EA & $Y$ & & $x$ & & & & & & \\
\hline Procure/Fab & $Y$ & & 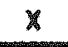 & $x$ & & & & & \\
\hline Window Work/Install & $Y$ & & & $x$ & & & & & \\
\hline \multicolumn{10}{|c|}{ TAXN $301-14$} \\
\hline \multicolumn{10}{|l|}{ Ts0i03 Evaluate Define } \\
\hline Auger Sampling/Analys is & $Y$ & $x$ & $x$ & & & & & & \\
\hline Core sampling/Analysis (NA) & $Y$ & $x$ & $x$ & & & & & & \\
\hline Data Interpretation & $Y$ & & $x$ & & & & & & \\
\hline Vapor sampling & $Y$ & $x$ & & & & & & & \\
\hline Vapor Analysis w/HSMS (PML) & $Y$ & $x$ & $x$ & & & & & & \\
\hline Window Hork & $Y$ & $x$ & $x$ & & & & & & see also Mitigation \\
\hline GRE Reports & $Y$ & $x$ & $x$ & & & & & & \\
\hline Gas Analysis Reports & $y$ & & $x$ & & & & & & \\
\hline In-situ Gas Sampling & $N$ & & & & & & & & dev under 104-AN \\
\hline Waste Behav Data Eval (PNL) & $Y$ & & $x$ & & & & & & \\
\hline \multicolumn{10}{|l|}{ Ts0105 Technology for Eval } \\
\hline Radialytic Mechanisms (AML) & H & & & & & & & & done under 101-5Y \\
\hline Chemical Mech (GIT/Other) & $Y$ & & $x$ & & & & & & \\
\hline Gas Generation (WHC/TBO) & $\checkmark$ & & $x$ & & & & & & \\
\hline Syntheric studies (PML) & $Y$ & & $x$ & & & & & & \\
\hline Org Methods Dev (PNL) & N & & & & & & & & done under $103-5 Y$ \\
\hline Start-Up New ISMS (PML) & H & & & & & & & & done under 101-sY \\
\hline Dev Methads for HSMS (PML) & $M$ & & & & & & & & done under 101-sY \\
\hline Physical Prop Methods Dev & $\sqrt{1}$ & & & & & & & & done under 103-SY \\
\hline
\end{tabular}


Table 6-1. Work Activities for the Flammable Gas Tank Safety Program.

\begin{tabular}{|c|c|c|c|c|c|c|c|c|c|}
\hline \multirow{2}{*}{ MORK JO8 } & \multirow{2}{*}{ Reol } & \multicolumn{6}{|c|}{.... NEEDED IN FISCAL YEAR $\ldots \ldots \ldots$} & \multirow{2}{*}{ JOA } & \multirow{2}{*}{ COMMENTS } \\
\hline & & 94 & 95 & 96 & 97 & 98 & 99 & & \\
\hline Physical Modeling (PML) & $\gamma$ & & $x$ & & & & & & \\
\hline Gas flow Model ing & $Y$ & $x$ & $x$ & & & & & & see also Mitigation \\
\hline Thermal Behavior & $Y$ & & $x$ & & & & & & \\
\hline \multicolumn{10}{|l|}{ TS0133 close Use/Resolve SI } \\
\hline Tech suppt use/wL screening & M & & & & & & & & done under 103-5Y \\
\hline USA Database Report & $Y$ & $x$ & $x$ & & & & & & \\
\hline Hazard Assessment & $\gamma$ & $x$ & & & & & & & \\
\hline Ssfety Documentation & $Y$ & $x$ & & & & & & & \\
\hline EAS & $Y$ & $x$ & & & & & & & \\
\hline Hydrogen Burn Analys is & $\gamma$ & & $x$ & & & & & & \\
\hline ISB/Close UsQ & $Y$ & & $x$ & & & & & & \\
\hline St Resolution & $Y$ & & & & & & & & after Retryl/Grout (12/07) \\
\hline \multicolumn{10}{|l|}{ TS0121 Monitoring Upgrades } \\
\hline Riser/Window Planning & $\gamma$ & $x$ & & & & & & & \\
\hline Gas Monitoring (SHMS) & $\mathbf{Y}$ & $\mathrm{x}$ & & & & & & & \\
\hline Repeir Existing TCs & $\mathbf{Y}$ & $x$ & & & & & & & \\
\hline MITs & $Y$ & $x$ & & & & & & & \\
\hline TMACS & $\gamma$ & $x$ & & & & & & & \\
\hline Surface Level & $\gamma$ & $x$ & & & & & & & \\
\hline TV Camera & $\varphi$ & $x$ & & & & & & & \\
\hline Ventilation & $N$ & & & & & & & & not required per Risk Assmt \\
\hline Permitting/MEPA & $H$ & & & & & & & & not required \\
\hline Density Trees & $Y$ & & $x$ & $x$ & & & & & if required \\
\hline Lightning Protection & M & & & & & & & & \\
\hline Mise IF Upgrades & $Y$ & & $x$ & & & & & & \\
\hline Equip Removl/Disposl/storage & $\gamma$ & & $x$ & & & & & & \\
\hline \multicolumn{10}{|l|}{ IS0122 Mitigation } \\
\hline Technology Dev/Model ing & 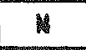 & & & & & & & & done under 101-5Y \\
\hline Mitigation Test & $m$ & & & & & & & & done under 101-sY \\
\hline Design & $Y$ & & $x$ & & & & & & \\
\hline SA/EA & $\varphi$ & & $x$ & $x$ & & & & & \\
\hline Procure/Fab & $Y$ & & $x$ & $x$ & $x$ & & & & \\
\hline Window Hork/Instal! & $y$ & & & & $x$ & & & & \\
\hline & & & & TAN & $906-1$ & & & & \\
\hline \multicolumn{10}{|l|}{ TS0103 Evaluate \& Define } \\
\hline Auger Sampling/Analys is & $Y$ & & $x$ & & & & & & \\
\hline Core Sampling/Analysis (N4) & $Y$ & & $x$ & $x$ & & & & & \\
\hline Data interpretation & $Y$ & & $x$ & $x$ & & & & & \\
\hline Vapor sampling & $Y$ & & $x$ & & & & & & \\
\hline Vapor Analysis w/HSMS (PNL) & $Y$ & & $x$ & $x$ & & & & & \\
\hline Window Work & $Y$ & & $x$ & $x$ & & & & & see also Mitigation \\
\hline GRE Reports & $Y$ & & $x$ & $x$ & & & & & \\
\hline Gas Analysis Reports & $Y$ & & $x$ & $x$ & & & & & \\
\hline
\end{tabular}


Table 6-1. Work Activities for the Flammable Gas Tank Safety Program.

\begin{tabular}{|c|c|c|c|c|c|c|c|c|c|}
\hline \multirow{2}{*}{ HORK JOO } & \multirow{2}{*}{ MEQD } & \multicolumn{6}{|c|}{ 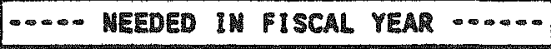 } & \multirow{2}{*}{$\begin{array}{c}\text { JOR } \\
\text { COMPLETE }\end{array}$} & \multirow{2}{*}{ COMMENTS } \\
\hline & & 94 & 95 & 96 & 87 & 98 & 99 & & \\
\hline In-Situ Gas Sampling & $Y$ & & $x$ & $x$ & & & & & \\
\hline Waste Behav Date Eval (PML) & $\gamma$ & & $x$ & $x$ & & & & & \\
\hline \multicolumn{10}{|l|}{ Tsoros Technology for Eval } \\
\hline Radiolytic Mechanism (AML) & $M$ & & & & & & & & Ione under 101.5Y \\
\hline Chemical mech (GIT/Other) & $Y$ & & $x$ & & & & & & \\
\hline Gas Generation (UHC/TBD) & $Y$ & & $x$ & & & & & & \\
\hline Synthetic Studies (PML) & $r$ & & $x$ & $x$ & & & & & \\
\hline Org Methods Dev (PHL) & $M$ & & & & & & & & done under $103-5 \%$ \\
\hline Start-UP Hew HSMS (PML) & 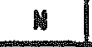 & & & & & & & & done under 101-5Y \\
\hline DeV Methods for HSMS (PML) & 彩 & & & & & & & & done under 101-\$Y \\
\hline Physical Prop Methods Dev & 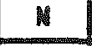 & & & & & & & & done under 103-sY \\
\hline Physical Modeling (PNL) & $Y$ & & $x$ & $x$ & & & & & \\
\hline Gas Flow Model ing & $Y$ & & $x$ & $x$ & & & & & sea also mitigation \\
\hline Thermel Behavior & $Y$ & & $x$ & $x$ & & & & & \\
\hline \multicolumn{10}{|l|}{ Is0133 close Usa/Resolve sI } \\
\hline Tech Suppt Usa/ul Sereming & H & & & & & & & & done under 103-5Y \\
\hline USQ Database Report & $Y$ & & $x$ & $x$ & & & & & \\
\hline Hazard Assessment & $\varphi$ & & $x$ & & & & & & \\
\hline Safety Documentation & $Y$ & & $x$ & & & & & & \\
\hline EAs & $\gamma$ & & $x$ & & & & & & \\
\hline Hydrogen Burn Analysis & 1 & & & $x$ & & & & & \\
\hline ISB/Close USA & $\gamma$ & & & $x$ & & & & & \\
\hline SI Resolution & 1 & & & & & & & & after Retrvl/Grout (12/10) \\
\hline \multicolumn{10}{|l|}{ Is0121 Monitoring Upgrades } \\
\hline Riser/Window Plaming & $\varphi$ & & $x$ & & & & & & \\
\hline Gas Monitoring (SHMS) & $Y$ & & $x$ & & & & & & \\
\hline Repair Existing TCS & $\gamma$ & $x$ & & & & & & & \\
\hline MrTs & $Y$ & & $x$ & & & & & & \\
\hline TMACS & $Y$ & & & & & & & $Y$ & \\
\hline Surface Level & $r$ & & $x$ & & & & & & \\
\hline TV Camera & $r$ & & $x$ & & & & & & \\
\hline Ventilation & $Y$ & & $x$ & & & & & & \\
\hline Permitting/NEPA & $\varphi$ & & $x$ & & & & & & \\
\hline Density Trees & $\gamma$ & & $x$ & $x$ & & & & & if required \\
\hline Lightring Protection & M & & & & & & & & \\
\hline Misc if Upgrades & $Y$ & & & $x$ & & & & & \\
\hline Equip Renovl/D ispos //Storage & $Y$ & & & $x$ & & & & & \\
\hline \multicolumn{10}{|l|}{ TSO122 Mitigation } \\
\hline Technology Dev/Podel ing & $N$ & & & & & & & & done under 101-5y \\
\hline Mitigation Test & $\mathrm{H}$ & & & & & & & & done under 101-sy \\
\hline Design & $Y$ & & & $x$ & & & & & \\
\hline SA/EA & $Y$ & & & $x$ & & & & & \\
\hline Procure/ Fab & $Y$ & & & $x$ & $x$ & & & & \\
\hline
\end{tabular}


Table 6-1. Work Activities for the Flammable Gas Tank Safety Program.

\begin{tabular}{|c|c|c|c|c|c|c|c|c|c|}
\hline \multirow{2}{*}{ HORK JOS } & \multirow{2}{*}{ RECo } & \multicolumn{6}{|c|}{ 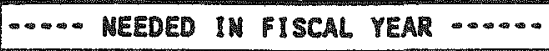 } & \multirow{2}{*}{$\begin{array}{c}\text { LOQ } \\
\text { COMPLETE }\end{array}$} & \multirow{2}{*}{ COAMENTS } \\
\hline & & 94 & 95 & 96 & 97 & 98 & 99 & & \\
\hline Hindow Work/Instal! & $\nabla$ & & & & $x$ & & & & \\
\hline \multicolumn{10}{|c|}{ 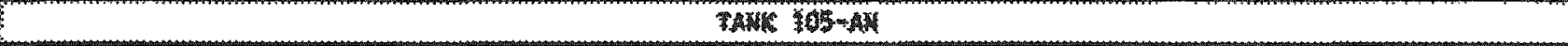 } \\
\hline \multicolumn{10}{|l|}{ T50103 Evaluate \& Define } \\
\hline Auger Sampling/Analys is & M & & & & & & & & crust doesn't trap gas \\
\hline Core Sampling/Analysis (N4) & $\gamma$ & & $x$ & $x$ & & & & & \\
\hline Data Interpretation & $Y$ & & $x$ & $x$ & & & & & \\
\hline Vapor Sampling & $Y$ & & $x$ & & & & & & \\
\hline Vapor Analysis W/HSMS (PNL) & $\varphi$ & & $x$ & $x$ & & & & & \\
\hline Hindow Hork & $y$ & & $x$ & $x$ & & & & & see also mitigation \\
\hline GRE Reports & $\vartheta$ & & $x$ & $x$ & & & & & \\
\hline Gas Analysis Reports & 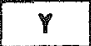 & & $x$ & $x$ & & & & & \\
\hline In-situ Gas sampling & $M$ & & & & & & & & dev under 104-AN \\
\hline Haste Behar Data Eval (PNL) & $Y$ & & $x$ & $x$ & & & & & \\
\hline \multicolumn{10}{|l|}{ Tsolos Technology for Eval } \\
\hline Radiolytic Mechanisms (AML) & 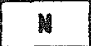 & & & & & & & & done under 101-5Y \\
\hline Chemical Mech (GIT/Other) & $Y$ & & $x$ & & & & & & \\
\hline Gas Generacion (WHC/TBO) & $Y$ & & $x$ & & & & & & \\
\hline Syntheric studies (PNL) & $Y$ & & $x$ & $x$ & & & & & \\
\hline Org Methods DeV (PNL) & $M$ & & & & & & & & done under 103-5y \\
\hline start-UP New HSMS (PML) & 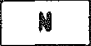 & & & & & & & & done under 101-5Y \\
\hline DeV Methods for HSMS (PNL) & H & & & & & & & & done under 101-sY \\
\hline Physical Prop Methods Dev & n & & & & & & & & done under $103-5 Y$ \\
\hline Physical Modeling (PNL) & $Y$ & & $x$ & $x$ & & & & & \\
\hline Gas flow Model ing & $Y$ & & $x$ & $x$ & & & & & see also Mitigation \\
\hline Thermal Behavior & $Y$ & & $x$ & $x$ & & & & & \\
\hline \multicolumn{10}{|l|}{ Tsol33 close Usa/Resolve 51} \\
\hline Tech Suppt USO/WL Screening & $M$ & & & & & & & & done under 103-sY \\
\hline USa Dacabase Report & $\gamma$ & & $x$ & $x$ & & & & & \\
\hline Hazard Assessment & $y$ & & $x$ & & & & & & \\
\hline Safety Documentation & $Y$ & & $x$ & & & & & & \\
\hline EAS & $\varphi$ & & $x$ & & & & & & \\
\hline Hydrogen Burn Analysis & $\gamma$ & & & $x$ & & & & & \\
\hline IsB/Close USQ & $Y$ & & & $x$ & & & & & \\
\hline Si Resolution & $Y$ & & & & & & & & after Retrvl/Grout (12/10) \\
\hline \multicolumn{10}{|l|}{ Ts0121 Monitoring Upgrades } \\
\hline Riser/Nindow Planning & $\varphi$ & & $x$ & & & & & & \\
\hline Gas Monitoring (SHMS) & $Y$ & & $x$ & & & & & & \\
\hline Repeir Existing TCs & $Y$ & $x$ & & & & & & & \\
\hline MITs & $Y$ & & $x$ & & & & & & \\
\hline TMACS & $Y$ & & & & & & & $Y$ & \\
\hline Surface Level & $Y$ & & $x$ & & & & & & \\
\hline TV Canera & M & & & & & & & & \\
\hline Ventilation & $Y$ & & $x$ & & & & & & \\
\hline
\end{tabular}


Table 6-1. Work Activities for the Flammable Gas Tank Safety Program.

\begin{tabular}{|c|c|c|c|c|c|c|c|c|c|}
\hline \multirow{2}{*}{ HORK JOS } & \multirow{2}{*}{ REOO } & \multicolumn{6}{|c|}{$\ldots \infty$ MEEDEO IM FISCAL YEAR $\cdots \infty$} & \multirow{2}{*}{$\begin{array}{c}\text { JOS } \\
\text { COMPLETE }\end{array}$} & \multirow{2}{*}{ COMPEENTS } \\
\hline & & 96 & 85 & 96 & 97 & 98 & 98 & & \\
\hline Permitting/NEPA & $Y$ & & $x$ & & & & & & \\
\hline Density Trees & M & & & & & & & & \\
\hline Lightning Protection & 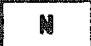 & & & & & & & & \\
\hline Misc If Upgrades & $Y$ & & & $x$ & & & & & \\
\hline Equip Removl/oisposl/storage & $Y$ & & & $x$ & & & & & \\
\hline \multicolumn{10}{|l|}{ Ts0122 Mitigation } \\
\hline Technology Dev/Model ing & N & & & & & & & & done under 101-5Y \\
\hline Mitigation Test & แ & & & & & & & & done under 101-5Y \\
\hline Design & $\gamma$ & & & $x$ & $x$ & & & & \\
\hline SA/EA & $\gamma$ & & & & $x$ & & & & \\
\hline Procure/Fab & $\gamma$ & & & & $x$ & $x$ & & & \\
\hline Window Work/Instal! & $Y$ & & & & & $x$ & & & \\
\hline \multicolumn{10}{|c|}{ 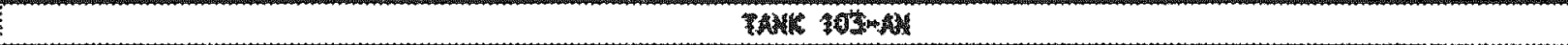 } \\
\hline \multicolumn{10}{|l|}{ TSO103 Evaluat: Define } \\
\hline Auger Szmpling/Analysis & M & & & & & & & & crust doesn't trap gas \\
\hline Core Sampling/Analysis (NA) & $Y$ & & $x$ & $x$ & & & & & \\
\hline Data interpretation & 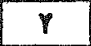 & & $x$ & $x$ & & & & & \\
\hline Vapor Sampling & $Y$ & & $x$ & & & & & & \\
\hline Vapor Analysis W/HSMS (PME) & $\gamma$ & & $x$ & $x$ & & & & & \\
\hline Window Work & $Y$ & & $x$ & $x$ & & & & & see also mitigation \\
\hline GRE Reports & $\gamma$ & & $x$ & $x$ & & & & & \\
\hline Gas Analysis Reports & $Y$ & & $x$ & $x$ & & & & & \\
\hline In-Situ Gas Sampling & N & & & & & & & & dev under $104-A M$ \\
\hline Waste Behav Data Eval (PNL) & $\gamma$ & & $x$ & $x$ & & & & & \\
\hline \multicolumn{10}{|l|}{ Ts0105 Technology for Eval } \\
\hline Radiolytic Mechanisns (AML) & W & & & & & & & & done under $101-5 Y$ \\
\hline Cherical Mech (GIT/Other) & $\varphi$ & & $x$ & & & & & & \\
\hline Gas Generation (WHC/TBO) & $Y$ & & $x$ & & & & & & \\
\hline Synthetic studies (PML) & $Y$ & & $x$ & $x$ & & & & & \\
\hline Org Methods Der (PNL) & M & & & & & & & & done under $103-5 \gamma$ \\
\hline Start-Up New HSMS (PML) & M & & & & & & & & done under 101-5Y \\
\hline Der Methods for MSMS (PNL) & H & & & & & & & & done under 101-5Y \\
\hline Physical Prop Methods Dey & N & & & & & & & & done under 103-sy \\
\hline Physical Modeling (PNL) & $\gamma$ & & $x$ & $x$ & & & & & \\
\hline Gas flow Model ing & $\gamma$ & & $x$ & $x$ & & & & & see also Mitigation \\
\hline Thermal Behavior & $Y$ & & $x$ & $x$ & & & & & \\
\hline \multicolumn{10}{|l|}{ TSO133 close USQ/Resolve SI } \\
\hline Tech Suppt UsQ/ML Screening & $M$ & & & & & & & & done under $103-5 y$ \\
\hline USQ Database Report & $\varphi$ & & $x$ & $x$ & & & & & \\
\hline Hazard Assessment & $Y$ & & $x$ & & & & & & \\
\hline Saf ety Docunentation & $Y$ & & $x$ & $x$ & & & & & \\
\hline EAs & $\gamma$ & & $x$ & & & & & & \\
\hline Hydrogen Burn Analysis & $Y$ & & & $x$ & & & & & \\
\hline
\end{tabular}


Table 6-1. Work Activities for the Flammable Gas Tank Safety Program.

\begin{tabular}{|c|c|c|c|c|c|c|c|c|c|}
\hline \multirow{2}{*}{ WORK LOS } & \multirow{2}{*}{ REOO } & \multicolumn{6}{|c|}{$\ldots \ldots$ MEEDED IN FISCAL YEAR $\cdots \cdots$} & \multirow{2}{*}{$\begin{array}{c}\text { JOQ } \\
\text { COMPLETE }\end{array}$} & \multirow{2}{*}{ COMMEMTS } \\
\hline & & 94 & 95 & 96 & 97 & 98 & 89 & & \\
\hline IS8/Close Usa & $Y$ & & & $x$ & & & & & \\
\hline 51 Resolution & $\gamma$ & & & & & & & & after Retrvl/Grout (12/10) \\
\hline \multicolumn{10}{|l|}{ Ts0121 Monitoring Upgrades } \\
\hline Riserfuindow Plaming & 1 & & $x$ & & & & & & \\
\hline Gas Monitoring (SHMS) & $Y$ & & $x$ & & & & & & \\
\hline Repair Existing TCs & $Y$ & $x$ & & & & & & & \\
\hline MITs & $\gamma$ & & $x$ & & & & & & \\
\hline TMACS & $\gamma$ & & & & & & & $\gamma$ & \\
\hline Surface Level & $Y$ & & $x$ & & & & & & \\
\hline TV Camera & M & & & & & & & & \\
\hline Ventilation & $Y$ & & $x$ & & & & & & \\
\hline Permitting/MEPA & $Y$ & & $x$ & & & & & & \\
\hline Density Trees & 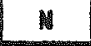 & & & & & & & & \\
\hline Lightning Protection & $M$ & & & & & & & & \\
\hline Misc if Upgrades & 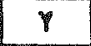 & & & $x$ & & & & & \\
\hline Equip Removl/o ispos//storage & $Y$ & & & $x$ & & & & & \\
\hline \multicolumn{10}{|l|}{ TS0122 Mitigation } \\
\hline Technolagy Dey/Model ing & $y$ & & & & & & & & done under 101-sy \\
\hline Mitigation Test & $M$ & & & & & & & & done under 101-SY \\
\hline Design & $Y$ & & & & & $x$ & & & \\
\hline SA/EA & $y$ & & & & & $x$ & $x$ & & \\
\hline Procure/fab & $Y$ & & & & & $x$ & $x$ & & \\
\hline Hindow Hork/Install & $Y$ & & & & & & & & complete $11 / 99$ \\
\hline \multicolumn{10}{|c|}{7 (1) } \\
\hline \multicolumn{10}{|l|}{ TS0103 Evaluate \& Define } \\
\hline Auger sampling/Analysis & N & & & & & & & & crust doesn't trap gas \\
\hline Cor Sampling/Analysis $(N 4)$ & $Y$ & & & $x$ & $x$ & & & & \\
\hline Data interpretation & $Y$ & & & & $x$ & & & & \\
\hline Vapor sampling & 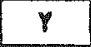 & & & $x$ & & & & & \\
\hline Vapor Analysis w/HSMS (PML) & $\gamma$ & & & $x$ & $x$ & & & & \\
\hline In-Tank/Field Work & 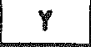 & & & $x$ & $x$ & & & & \\
\hline GRE Reports & $M$ & & & & & & & & no gas releese events \\
\hline Gas Analysis Reports & $\gamma$ & & & $x$ & $x$ & & & & \\
\hline In-situ Gas sampling & M & & & & & & & & dev under 104-AM \\
\hline Waste Behav Data Eval (PNL) & $\gamma$ & & & $x$ & $x$ & & & & \\
\hline \multicolumn{10}{|l|}{ TSO105 Technology for Eval } \\
\hline Radiolytic Mechanisms (AML) & $M$ & & & & & & & & done under 101-5Y \\
\hline Chemical Mech (GIT/Other) & $M$ & & & & & & & & not regd for SST's \\
\hline Gas Generation (WHC/TBO) & $M$ & & & & & & & & not regd for SSTs \\
\hline Syntheric Studies (PNL) & M & & & & & & & & not regd for SSTs \\
\hline Org Methods Dev (PNL) & M & & & & & & & & done under $103-5 y$ \\
\hline Start-UP NeW HSMS (PML) & N & & & & & & & & done under 101-5Y \\
\hline Dev Methods for HSMS (PNL) & N & & & & & & & & done under $101-5 Y$ \\
\hline
\end{tabular}


Table 6-1. Work Activities for the Flammable Gas Tank Safety Program.

\begin{tabular}{|c|c|c|c|c|c|c|c|c|c|}
\hline \multirow{2}{*}{ WORK JOB } & \multirow{2}{*}{ REOO } & \multicolumn{6}{|c|}{$-\infty \cdots$ MEEDED IN FISCAL YEAR $\cdots \cdots$} & \multirow{2}{*}{$\begin{array}{c}\text { JOB } \\
\text { COMPLETE }\end{array}$} & \multirow{2}{*}{ COMMENTS } \\
\hline & & 94 & 95 & 96 & 97 & 98 & 99 & & \\
\hline Physieal Prop Methods Dev & $M$ & & & & & & & & done under 103-5Y \\
\hline Physical Modeling (PNL) & $\gamma$ & & & & $x$ & & & & \\
\hline Gas Plow Model ing & $Y$ & & & & $x$ & & & & conplete under AN farm \\
\hline Thergal Behavior & N & & & & & & & & \\
\hline \multicolumn{10}{|l|}{ Isol33 close Use/Resolve SI } \\
\hline Tech suppt Usa/ML screening & M & & & & & & & & done under $103-5 Y$ \\
\hline USe Database Report & H & & & & & & & & complete under AN farmi \\
\hline Hazard Assessment & $Y$ & & $x$ & $x$ & & & & & \\
\hline Safery Documentetion & $Y$ & & & $x$ & $x$ & & & & \\
\hline EAs & $Y$ & & & $x$ & $x$ & & & & \\
\hline Mydrogen Burn Analys is & $Y$ & & & & $x$ & & & & \\
\hline ISE/Close USA & $Y$ & & & & $x$ & $x$ & & & \\
\hline SI Resolution & $Y$ & & & & & & $x$ & & after monitoring upgrds \\
\hline \multicolumn{10}{|l|}{ IS0121 Monitoring Upgrades } \\
\hline Riserfwindow Plaming & $Y$ & & & $x$ & & & & & \\
\hline Gas Monitoring (SHMS) & $Y$ & & & $x$ & & & & & \\
\hline Repair Existing TCS & $Y$ & $x$ & & & & & & & \\
\hline MITs & $\gamma$ & & & & $x$ & & & & \\
\hline TMACS & $Y$ & & $x$ & & & & & & sx farm by organic Program \\
\hline Surface Level & $\gamma$ & & & & $x$ & & & & \\
\hline IV Canera & M & & & & & & & & \\
\hline Ventilation & $Y$ & & & & & $x$ & & & \\
\hline Permitting/NEPA & $\gamma$ & & & & & $x$ & & & \\
\hline Dens i iy Trees & $M$ & & & & & & & & \\
\hline Lightning Protection & $N$ & & & & & & & & \\
\hline Misc if Upgrades & H & & & & & & & & \\
\hline Equip Removl/D ispos l/storage & $Y$ & & & & $x$ & & & & \\
\hline \multicolumn{10}{|l|}{ TS0122 Mitigation } \\
\hline Technology Dey/Model ing & $M$ & & & & & & & & mitigation not regd \\
\hline Mitigation Test & H & & & & & & & & "18 \\
\hline Design & $N$ & & & & & & & & 8 \\
\hline SA/EA & 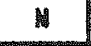 & & & & & & & & "18 \\
\hline Procure/Fab & 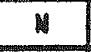 & & & & & & & & 10 \\
\hline Uindow Work/Install & H & & & & & & & & 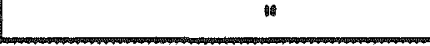 \\
\hline & & & & PANK & $101+1$ & & & & \\
\hline \multicolumn{10}{|l|}{ Tso103 Evaluace \& Define } \\
\hline Auger Sampling/Analysis & N & & & & & & & & crust doesn't trap gas \\
\hline Core Sampling/Analysis (M4) & $Y$ & & & $x$ & $x$ & & & & \\
\hline Data interpretation & $Y$ & & & & $x$ & & & & \\
\hline Vapor sampling & $Y$ & & & $x$ & & & & & \\
\hline Vapor Analysis w/HSMS (PNL) & $Y$ & & & $x$ & $x$ & & & & \\
\hline In-Tank/Field Work & $Y$ & & & $x$ & $x$ & & & & \\
\hline GRE Reports & N & & & & & & & & no gas release svents \\
\hline
\end{tabular}


Table 6-1. Work Activities for the Flammable Gas Tank Safety Program.

\begin{tabular}{|c|c|c|c|c|c|c|c|c|c|}
\hline \multirow{2}{*}{ WORK JOS } & \multirow{2}{*}{ REOQ } & \multicolumn{6}{|c|}{$\ldots \ldots$ MEEDED IN FISCAL YEAR $\cdots \ldots$} & \multirow{2}{*}{$\begin{array}{c}\text { JOS } \\
\text { COMPLETE }\end{array}$} & \multirow{2}{*}{ COAMENTS } \\
\hline & & 94 & 85 & 96 & 97 & 98 & 99 & & \\
\hline Gas Andys is Reports & $Y$ & & & $x$ & $x$ & & & & \\
\hline In-situ cas sampling & H & & & & & & & & dev under $104-A M$ \\
\hline Waste Gehav Data Eval (PML) & $\gamma$ & & & $x$ & $x$ & & & & \\
\hline \multicolumn{10}{|l|}{ Tso105 Technology for Eval } \\
\hline Radiolytic Mechanisms (AML) & M & & & & & & & & done under 101-5\% \\
\hline Chemical Mech (GIT/Other) & 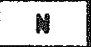 & & & & & & & & nat regd for ssts \\
\hline Gas Generation (HMC/TBO) & N & & & & & & & & not regd for SSTs \\
\hline Synthetic Studies (PML) & H & & & & & & & & not regd for SSTs \\
\hline Org Methods Dev (PNL) & y & & & & & & & & done under 103-5Y \\
\hline Start-Up Nes hSMS (PNL) & * & & & & & & & & done under $101-5 Y$ \\
\hline Dev Methods for HSMS (PML) & M & & & & & & & & done under 101-SY \\
\hline Physical Prop Methods Dev & N & & & & & & & & done under $103-5 Y$ \\
\hline Physical Model ing (PML) & 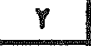 & & & & $x$ & & & & \\
\hline Gas Flow Model ing & $Y$ & & & & $x$ & & & & \\
\hline Thermal Behavior & 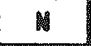 & & & & & & & & complete under AN farm \\
\hline \multicolumn{10}{|l|}{ TSO133 Close USO/Resolve SI } \\
\hline Tech Suppt Usa/ML Sereening & H & & & & & & & & done under 103-sy \\
\hline Usa Database Report & H & & & & & & & & complete under AM farm \\
\hline Hazard Assessment & $\gamma$ & & $x$ & $x$ & & & & & \\
\hline Safery Documentation & $Y$ & & & $x$ & $x$ & & & & \\
\hline EAs & $Y$ & & & $x$ & $x$ & & & & \\
\hline Hydrogen Burn Analysis & $Y$ & & & & $x$ & & & & \\
\hline 158/Close USO & $Y$ & & & & $x$ & $x$ & & & \\
\hline St Resolution & $\gamma$ & & & & & & $x$ & & after monitoring upgrds \\
\hline \multicolumn{10}{|l|}{ TS0121 Monitoring Upgrades } \\
\hline Riser/Hindou Plaming & $\gamma$ & & & $x$ & & & & & \\
\hline Gas Monitoring (SHMS) & $\gamma$ & & & $x$ & & & & & \\
\hline Repair Existing TCs & $\gamma$ & $x$ & & & & & & & \\
\hline MITs & $\varphi$ & & & & $x$ & & & & \\
\hline TMACS & $\gamma$ & & & $x$ & & & & & \\
\hline Surfiace Level & $\gamma$ & & & & $x$ & & & & \\
\hline TV Camera & $y$ & & & & & & & & \\
\hline Ventilarion & $Y$ & & & & $x$ & & & & \\
\hline Permitting/NePA & $\gamma$ & & & & $x$ & & & & \\
\hline Density Trees & $N$ & & & & & & & & \\
\hline Lightning Protection & $n$ & & & & & & & & \\
\hline Misc Tf Upgrades & H & & & & & & & & \\
\hline Equip Renovl/D ispos / / Storage & $Y$ & & & & $x$ & & & & \\
\hline \multicolumn{10}{|l|}{ Ts0122 Mitigation } \\
\hline Technology Dev/Model ing & $H$ & & & & & & & & mitigation not regd \\
\hline Mitigation Test & N & & & & & & & & 8 \\
\hline Design & H & & & & & & & & 118 \\
\hline SA/EA & M & & & & & & & & $\because$ \\
\hline
\end{tabular}


Table 6-1. Work Activities for the Flammable Gas Tank Safety Program.

\begin{tabular}{|c|c|c|c|c|c|c|c|c|c|}
\hline \multirow{2}{*}{ HORK JOS } & \multirow{2}{*}{ REQD } & \multicolumn{6}{|c|}{$\ldots \ldots$ NEEDED IN FISCAL YEAR $\ldots \ldots$} & \multirow{2}{*}{$\begin{array}{c}\text { JOS } \\
\text { COAPLETE }\end{array}$} & \multirow{2}{*}{ COMAENTS } \\
\hline & & 84 & 95 & 96 & 97 & 98 & 99 & & \\
\hline Procure/Fab & H & & & & & & & & 18 \\
\hline Window Hork/Instal! & N & & & & & & & & "9 \\
\hline 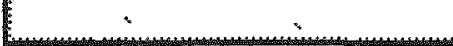 & & & & TAM & 102 & & & & $\therefore$ \\
\hline \multicolumn{10}{|l|}{ IS0103 Evaluate Define } \\
\hline Auger Sampling/Analysis & 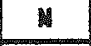 & & & & & & & & erust doesn't trap gas \\
\hline Core Sampling/Analysis (N4) & $\varphi$ & & & $x$ & $x$ & & & & \\
\hline Data interpretation & $\varphi$ & & & & $x$ & & & & \\
\hline Vapor Sempling & $Y$ & & & $x$ & & & & & \\
\hline Vapor Analysis W/HSMS (PML) & 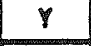 & & & $x$ & $x$ & & & & \\
\hline In-Tank/Field Work & $Y$ & & & $x$ & $x$ & & & & \\
\hline GRE Reports & $M$ & & & & & & & & no gas release events \\
\hline Gas Andys is Reports & $y$ & & & $x$ & $x$ & & & & \\
\hline In-Situ Gas Sampling & 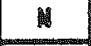 & & & & & & & & dev under 104-AM \\
\hline Haste Behav Data Evil (PNL) & $Y$ & & & $x$ & $x$ & & & & \\
\hline \multicolumn{10}{|l|}{ TSO105 Technology for Eval } \\
\hline Radiolytic Mechanisms (ANL) & N & & & & & & & & done under 101-5y \\
\hline Chenical Mech (GIT/Other) & $M$ & & & & & & & & not regd for ssts \\
\hline Gas Generation (WHC/TBO) & H & & & & & & & & not regd for ssts \\
\hline Syntherfic studies (PML) & H & & & & & & & & not read for ssts \\
\hline Org Methods Dev (PML) & H & & & & & & & & done under 103.5Y \\
\hline Start-UP Mew HSMS (PML) & M & & & & & & & & done under $101-5 Y$ \\
\hline Dev Methods for HSMS (PNL) & N & & & & & & & & done under 101-5Y \\
\hline Phys ical Prop Methods Dev & M & & & & & & & & done under 103-sY \\
\hline Physical Modeling (PNL) & $\gamma$ & & & & $x$ & & & & \\
\hline Gas Flow Model ing & $Y$ & & & & $x$ & & & & \\
\hline Thermal Behavior & M & & & & & & & & complete under AN farm \\
\hline \multicolumn{10}{|l|}{ TSo133 Close USO/Resolve sI } \\
\hline Tech suppt USO/ML screening & M & & & & & & & & done under 103-5Y \\
\hline USO Database Report & H & & & & & & & & complete under AM farm \\
\hline Hazard Assessment & $Y$ & & $x$ & $x$ & & & & & \\
\hline Safety Documentation & $Y$ & & & $x$ & $x$ & & & & \\
\hline EAs & $\gamma$ & & & $x$ & $x$ & & & & \\
\hline Hydrogen Burn Analysis & $Y$ & & & & $x$ & & & & \\
\hline Is8/close Usa & $Y$ & & & & $x$ & $x$ & & & \\
\hline S1 Resolution & $Y$ & & & & & & $x$ & & after monitoring upgrds \\
\hline \multicolumn{10}{|l|}{ Ts0121 Monitoring Upgrades } \\
\hline Riser/Window Planning & $Y$ & & & $x$ & & & & & \\
\hline Gas Moni toring (SHMS) & $Y$ & & & $x$ & & & & & \\
\hline Repair Existing TCS & $r$ & $x$ & & & & & & & \\
\hline MITs & $Y$ & & & & $x$ & & & & \\
\hline TMACS & $Y$ & & $x$ & & & & & & by Organic progran \\
\hline Surface Level & $Y$ & & & & $x$ & & & & \\
\hline TV Camera & $y$ & & & & & & & & \\
\hline
\end{tabular}


Table 6-1. Work Activities for the Flammable Gas Tank Safety Program.

\begin{tabular}{|c|c|c|c|c|c|c|c|c|c|}
\hline \multirow{2}{*}{ HORK JOR } & \multirow{2}{*}{ REOO } & \multicolumn{6}{|c|}{$\ldots \ldots$ NEEDED IN FISCAL YEAR $\ldots \ldots$} & \multirow{2}{*}{$\begin{array}{c}\text { JOB } \\
\text { COAPLETE }\end{array}$} & \multirow{2}{*}{ COMNENTS } \\
\hline & & 94 & 95 & 96 & 97 & 98 & 99 & & \\
\hline Ventilation & $\gamma$ & & & & & $x$ & & & \\
\hline Permitting/MEPA & $\gamma$ & & & & & $x$ & & & \\
\hline Density Trees & $M$ & & & & & & & & \\
\hline Lightning Protection & $M$ & & & & & & & & \\
\hline Misc If Upgrades & N & & & & & & & & \\
\hline Equip Renovl/Disposl/storage & $\gamma$ & & & & $x$ & & & & \\
\hline \multicolumn{10}{|l|}{ TSO122 Mitigation } \\
\hline rechnology Dev/Model ing & N & & & & & & & & mitigation not regd for \\
\hline Mitigation Test & H & & & & & & & & Flam Gas: by Organic if \\
\hline Design & H & & & & & & & & required \\
\hline SA/EA & N & & & & & & & & Ba \\
\hline Procure/fab & H & & & & & & & & 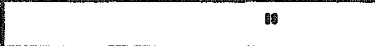 \\
\hline Hindow Hork/Install & 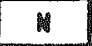 & & & & & & & & "8 \\
\hline \multicolumn{10}{|c|}{ 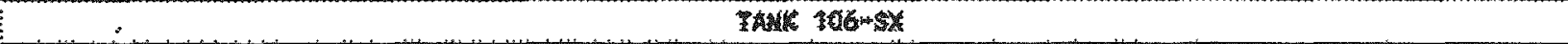 } \\
\hline \multicolumn{10}{|l|}{ Ts0103 Evaluate \& Define } \\
\hline Auger Sampling/Analysis & M & & & & & & & & crust doesn't trap gas \\
\hline Core Sampling/Analys is (NG) & $Y$ & & & $x$ & $x$ & & & & \\
\hline Data interpretation & $Y$ & & & & $x$ & & & & \\
\hline Vepor sampling & $Y$ & & & $x$ & & & & & \\
\hline Vapor Analys is W/HSMS (PML) & $Y$ & & & $x$ & $x$ & & & & \\
\hline in-Tank/field Hork & $Y$ & & & $x$ & $x$ & & & & \\
\hline GRE Reports & M & & & & & & & & no gas releese events \\
\hline Gas Analysis Reports & $Y$ & & & $x$ & $x$ & & & & \\
\hline In-Situ Gas Sampling & N & & & & & & & & dev under 104-AM \\
\hline Waste Behav Data Eval (PNL) & $\gamma$ & & & $x$ & $x$ & & & & \\
\hline \multicolumn{10}{|l|}{ Ts0105 Technology for Eval } \\
\hline Radiolytic Mechanisms (AML) & M & & & & & & & & done under 101-SY \\
\hline Chemical Mech (GIT/Other) & H & & & & & & & & not ragd for SSTs \\
\hline Gas Generation (UMC/TBD) & $M$ & & & & & & & & not regd for SSTs \\
\hline Syntheric studies (PML) & $M$ & & & & & & & & not regd for SSTs \\
\hline Org Methods DeV (PML) & H & & & & & & & & done under $103-5 y$ \\
\hline Start-Up New HSMS (PML) & $M$ & & & & & & & & done under 101-5Y \\
\hline DeV Methods for HSMS (PNL) & M & & & & & & & & done under 101-5Y \\
\hline Physical Prop Methods Dev & H & & & & & & & & done under $103-51$ \\
\hline Physical Model ing (PNL) & $\varphi$ & & & & $x$ & & & & \\
\hline Gas flow Modeling & $Y$ & & & & $x$ & & & & \\
\hline Thermal Behavior & H & & & & & & & & complete under AN farm \\
\hline \multicolumn{10}{|l|}{ Iso133 close Usa/Resolve SI } \\
\hline Tech Suppt USQ/UL Screening & $M$ & & & & & & & & done under 103-5Y \\
\hline Usa Database Report & M & & & & & & & & complete under AN farm \\
\hline Hezard Assessment & $\gamma$ & & $x$ & $x$ & & & & & \\
\hline Safety Documentation & $Y$ & & & $x$ & $x$ & & & & \\
\hline EAs & $Y$ & & & $x$ & $x$ & & & & \\
\hline
\end{tabular}


Table 6-1. Work Activities for the Flammable Gas Tank Safety Program.

\begin{tabular}{|c|c|c|c|c|c|c|c|c|c|}
\hline \multirow{2}{*}{ WORK JOB } & \multirow{2}{*}{ RED } & \multicolumn{6}{|c|}{ 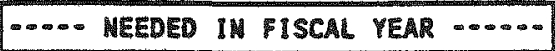 } & \multirow{2}{*}{ COMPLETE } & \multirow{2}{*}{ COMMENTS } \\
\hline & & 96 & 95 & 96 & 97 & 98 & 99 & & \\
\hline Hydrogen Burn Anglys is & $\varphi$ & & & & $x$ & & & & \\
\hline ise/Close USA & $\gamma$ & & & & $x$ & $x$ & & & \\
\hline SI Resolution & $\gamma$ & & & & & & $x$ & & after monitoring upgrds \\
\hline \multicolumn{10}{|l|}{ TS0121 Monitoring Upgradas } \\
\hline Riser/Window Planning & 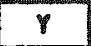 & & & $x$ & & & & & \\
\hline Gas Monitoring (SHMS) & $\gamma$ & & & $x$ & & & & & \\
\hline Repair Existing TCS & $Y$ & $x$ & & & & & & & \\
\hline MITs & $Y$ & & & & $x$ & & & & \\
\hline TMACS & $\gamma$ & & $x$ & & & & & & by Organic program \\
\hline Surface bevel & $\gamma$ & & & & $x$ & & & & \\
\hline TV Camera & $N$ & & & & & & & & \\
\hline Ventilation & $Y$ & & & & & $x$ & & & \\
\hline Permitting/NEPA & 1 & & & & & $x$ & & & \\
\hline Densiby Iroes & H & & & & & & & & \\
\hline Lightning Protection & H & & & & & & & & \\
\hline Misc if Upgrades & $M$ & & & & & & & & \\
\hline Equip Removl/Dispos l/storage & 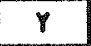 & & & & $x$ & & & & \\
\hline \multicolumn{10}{|l|}{ Ts0122 Mirigation } \\
\hline Technology Dev/Model ing & $M$ & & & & & & & & mitigation not read for \\
\hline Mitigation Test & 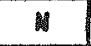 & & & & & & & & Flam Gas: by Organic if \\
\hline Design & 19 & & & & & & & & required \\
\hline SA/EA & 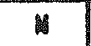 & & & & & & & & "10 \\
\hline Procure/fab & 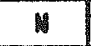 & & & & & & & & " \\
\hline Window Hork/Install & H & & & & & & & & : \\
\hline & & & & 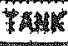 & $00 \%$ & & & & \\
\hline \multicolumn{10}{|l|}{ Tso103 Evaluate \& Define } \\
\hline Auger Sampling/Analysis & M & & & & & & & & erust doesn't trap gas \\
\hline Core Sampling/Analysis (N4) & $Y$ & & & & $x$ & & & & \\
\hline Data Interpretation & $Y$ & & & & $x$ & & & & \\
\hline Vapor Sampl ing & $Y$ & & & $x$ & & & & & \\
\hline Vapor Analysis w/HSMS (PNL) & $\gamma$ & & & $x$ & $x$ & & & & \\
\hline In-Tank/field Hork & $\varphi$ & & & $x$ & $x$ & & & & \\
\hline GRE Reports & w & & & & & & & & no gas release events \\
\hline Gas Analysis Reports & $\gamma$ & & & $x$ & $x$ & & & & \\
\hline In-situ Gas sampling & M & & . & & & & & & dev under 104-AN \\
\hline Waste Behav Data Eval (PNL) & $Y$ & & & $x$ & $x$ & & & & \\
\hline \multicolumn{10}{|l|}{ Tso10s Technology for Eval } \\
\hline Radialytic Mechanisms (ANL) & $H$ & & & & & & & & done under 101-5Y \\
\hline Chemical Mech (GIT/Other) & H & & & & & & & & not reqd for SSTs \\
\hline Gas Generation (WHC/TBD) & H & & & & & & & & not regd for SsTs \\
\hline Synthetic Studies (PML) & $\omega$ & & & & & & & & not regd for SSTs \\
\hline Org Methods Dev (PHL) & N & & & & & & & & done under 103-5Y \\
\hline Start-UP Neน HSMS (PML) & $H$ & & & & & & & & done under 101-5Y \\
\hline
\end{tabular}


Table 6-1. Work Activities for the Flammable Gas Tank Safety Program.

\begin{tabular}{|c|c|c|c|c|c|c|c|c|c|}
\hline \multirow{2}{*}{ MORK } & \multirow{2}{*}{ MeOS } & \multicolumn{6}{|c|}{$\ldots \ldots \infty$ MEEDED IN FISCAL YEAR $\ldots \ldots \ldots$} & \multirow{2}{*}{$\begin{array}{c}\text { JOB } \\
\text { COMPLETE }\end{array}$} & \multirow{2}{*}{ COAMENTS } \\
\hline & & 94 & 95 & 96 & 97 & 98 & 99 & & \\
\hline DeV Methods for HSMS (PML) & 邹 & & & & & & & & done under 101-5Y \\
\hline Physical Prop Methods Dev & $w$ & & & & & & & & done under 103-5Y \\
\hline Physical Model ing (PNL) & $Y$ & & & & $x$ & & & & \\
\hline Gas Flom Model ing & $Y$ & & & & $x$ & & & & \\
\hline Thermal Behavior & M & & & & & & & & complete under AN farm \\
\hline \multicolumn{10}{|l|}{ TS0133 Close USQ/Resolve $\$$} \\
\hline Tech Suppt USQ/ML Screening & $N$ & & & & & & & & done under $103-\$ 4$ \\
\hline Usa Database Report & M & & & & & & & & complete under AN farm \\
\hline Mazard Assessment & $Y$ & & $x$ & $x$ & & & & & \\
\hline Safety Documentation & $\gamma$ & & & $x$ & $x$ & & & & \\
\hline EAs & $P$ & & & $x$ & $x$ & & & & \\
\hline Hydrogen Bum Analysis & $Y$ & & & & $x$ & & & & \\
\hline ISB/Close USO & $\gamma$ & & & & $x$ & $x$ & & & \\
\hline st Resolution & $\gamma$ & & & & & & $x$ & & after monitoring upgrds \\
\hline \multicolumn{10}{|l|}{ Tso121 Monitoring Upgrades } \\
\hline Riser/Mindow Planning & $Y$ & & & $x$ & & & & & \\
\hline Gas Monitoring (SHMS) & $\gamma$ & & & $x$ & & & & & \\
\hline Repair Existing TCS & $\nabla$ & $x$ & & & & & & & \\
\hline MITs & $Y$ & & & & $x$ & & & & \\
\hline TMACS & $Y$ & & & $x$ & & & & & \\
\hline Surface Level & $Y$ & & & & $x$ & & & & \\
\hline TV Camery & N & & & & & & & & \\
\hline Ventilation & $\gamma$ & & & & $x$ & & & & \\
\hline Permitting/NEPA & $Y$ & & & & $x$ & & & & \\
\hline Density Trees & N & & & & & & & & \\
\hline Lightning Protection & N & & & & & & & & \\
\hline Misc if Upgrades & H & & & & & & & & \\
\hline Equip Removl/o isposl/storage & $Y$ & & & & $x$ & & & & \\
\hline \multicolumn{10}{|l|}{ TS0122 mitigation } \\
\hline Technology Dev/Model ing & M & & & & & & & & mitigation not regd \\
\hline Mitigation Test & N & & & & & & & & 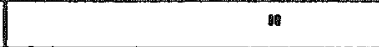 \\
\hline Design & M & & & & & & & & 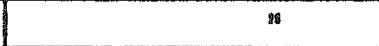 \\
\hline SA/EA & M & & & & & & & & s \\
\hline Procure/Fab & N & & & & & & & & 10 \\
\hline Hindow Work/Install & N & & & & & & & & 18 \\
\hline \multicolumn{10}{|c|}{ TAHAY 10S-U } \\
\hline \multicolumn{10}{|l|}{ Ts0103 Evaluate \& Define } \\
\hline Auger Sampling/Analysis & $M$ & & & & & & & & crust doesn't trap gas \\
\hline Core Sampling/Analysis (NG) & 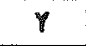 & & & & $x$ & & & & \\
\hline Data interpretation & $\bar{Y}$ & & & & $x$ & & & & \\
\hline Vapor Sampling & $Y$ & & & $x$ & & & & & \\
\hline Vapor Analysis W/HSMS (PML) & $Y$ & & & $x$ & $x$ & & & & \\
\hline In-Tank/Field Work & $y$ & & & $x$ & $x$ & & & & \\
\hline
\end{tabular}


Table 6-1. Work Activities for the Flammable Gas Tank Safety Program.

\begin{tabular}{|c|c|c|c|c|c|c|c|c|c|}
\hline \multirow{2}{*}{ MORK JOS } & \multirow{2}{*}{ REOS } & \multicolumn{6}{|c|}{ 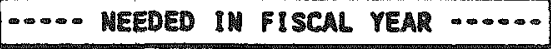 } & \multirow{2}{*}{$\begin{array}{c}\text { JOS } \\
\text { COMPLETE }\end{array}$} & \multirow{2}{*}{ COMMENTS } \\
\hline & & 96 & 95 & 86 & 97 & 98 & 99 & & \\
\hline GRE Reports & N & & & & & & & & no gras release events \\
\hline Gas Anolysis Reports & $y$ & & & $x$ & $x$ & & & & \\
\hline In-Situ Gas sampling & 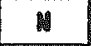 & $\therefore$ & & & & & & & dev under 104-AM \\
\hline Haste Sehav Data Eval (PML) & $Y$ & & & $x$ & $x$ & & & & \\
\hline \multicolumn{10}{|l|}{ Ts0105 Technology for Eval } \\
\hline Radiolytic Mechanisms (AML) & W & & & & & & & & done under 101-5y \\
\hline Chemical Mech (GIT/Other) & $M$ & & & & & & & & not regd for SSTs \\
\hline Gas Generation (WHC/TBD) & H & & & & & & & & not regd for SSTs \\
\hline Synthetic Studies (PNL) & N & & & & & & & & not regd for SSTS \\
\hline Org Methods DeV (PNL) & M & . & & & & & & & done under 103-5Y \\
\hline Start-UP New HSMS (PHL) & H & & & & & & & & done under 101-5Y \\
\hline Dev Methods for HSMS (PNL) & 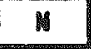 & & & & & & & & done under 101-5Y \\
\hline Physieal Prop Methods Der & $M$ & & & & & & & & done under 103-5Y \\
\hline Physicat Modeling (PML) & $\gamma$ & & & & $x$ & & & & \\
\hline Gas Flow Modeling & $\gamma$ & & & & $x$ & & & & \\
\hline Thermal Behavior & t & & & & & & & & complete under AN farm \\
\hline \multicolumn{10}{|l|}{ Ts0133 Close Usa/Resolve 5} \\
\hline Tech Suppt USQ/UL Screening & $N$ & & & & & & & & done under $103-5 Y$ \\
\hline USa Database Report & N & & & & & & & & complete under AN farm \\
\hline Hazard Assessment & 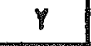 & & & $x$ & $x$ & & & & \\
\hline Safecy Documentation & $\gamma$ & & & $x$ & $x$ & & & & \\
\hline EAs & $Y$ & & & $x$ & $x$ & & & & \\
\hline Hydrogen Burn Analysis & Y & & & & & $x$ & & & \\
\hline Ise/close Usa & 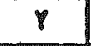 & & & & $x$ & $x$ & & & \\
\hline S1 Resolution & $\vartheta$ & & & & & & $x$ & & [after monitoring upgrds \\
\hline \multicolumn{10}{|l|}{ Ts0121 Monitoring Upgrades } \\
\hline Riser/Window Planning & $Y$ & & & $x$ & & & & & \\
\hline Gas Monitroring (SHMS) & $\gamma$ & & & $x$ & & & & & \\
\hline Repair Existing TCs & $Y$ & $x$ & & & & & & & \\
\hline MITS & $Y$ & & & & $x$ & & & & \\
\hline TMACS & $y$ & & $x$ & & & & & & by Organic Program \\
\hline surface Level & 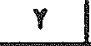 & & & & $x$ & & & & \\
\hline TV Camera & H & & & & & & & & \\
\hline Ventilation & $Y$ & & & & & & $x$ & & \\
\hline Permitting/NEPA & Y & & & & & & $x$ & & \\
\hline Dens ity Trees & $M$ & & & & & & & & \\
\hline Lightning Protection & $M$ & & & & & & & & \\
\hline Mise If Upgrades & $N$ & & & & & & & & \\
\hline Equip Removl/0 ispos //Storage & $\vartheta$ & & & & & $x$ & & & \\
\hline \multicolumn{10}{|l|}{ TS0122 Mitigation } \\
\hline Technology Dev/Modeling & H & & & & & & & & mitigation not regd \\
\hline Mitigation Test & H & & & & & & & & 3 \\
\hline Design & N & & & & & & & & 10 \\
\hline
\end{tabular}


Table 6-1. Work Activities for the Flammable Gas Tank Safety Program.

\begin{tabular}{|c|c|c|c|c|c|c|c|c|c|}
\hline \multirow{2}{*}{ WORK JOS } & \multirow{2}{*}{ RECO } & \multicolumn{6}{|c|}{ 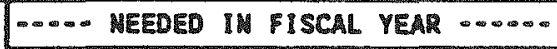 } & \multirow{2}{*}{$\begin{array}{c}\text { JOS } \\
\text { COAPLETE }\end{array}$} & \multirow{2}{*}{ COAAMENTS } \\
\hline & & 94 & 85 & 96 & 97 & 98 & 99 & & \\
\hline SA/EA & N & & & & & & & & "6 \\
\hline Procura/ Pab & M & & & & & & & & "60 \\
\hline Hindow Hork/Install & $N$ & & & & & & & & ti \\
\hline \multicolumn{10}{|c|}{ 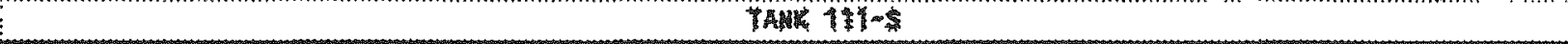 } \\
\hline \multicolumn{10}{|l|}{ TS0103 Evaluate Define } \\
\hline Auger Sampl ing/Analysis & 野 & & & & & & & & crust doesn' trap gas \\
\hline Core Sampling/Analysis (N4) & $Y$ & & & & $x$ & & & & \\
\hline Date interpretation & $Y$ & & & & $x$ & & & & \\
\hline Vapor Sampling & $Y$ & & & & $x$ & & & & \\
\hline Vapor Analysis W/HSAS (PNL) & 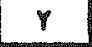 & & & & $x$ & & & & \\
\hline In-Tank/field Work & $Y$ & & & & $x$ & & & & \\
\hline GRE Reports & $N$ & & & & & & & & no gas release events \\
\hline Gas Analys is Reports & $Y$ & & & & $x$ & & & & \\
\hline In-situ Gas Sampling & N & & & & & & & & dev under 104-AM \\
\hline Waste Behav Data Eval (PNL) & $Y$ & & & & $x$ & & & & \\
\hline \multicolumn{10}{|l|}{ Ts0105 Technology for Eval } \\
\hline Radialytic Mechenisms (AML) & H & & & & & & & & done under 101-51 \\
\hline Chemical Mech (GIT/Other) & H & & & & & & & & not regd for SSTs \\
\hline Gas Generstion (WHC/TBD) & 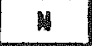 & & & & & & & & not regd for SSTs \\
\hline Synthetic studies (PML) & $H$ & & & & & & & & not regd for sSTs \\
\hline Org Methods Dev (PML) & 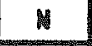 & & & & & & & & done under $103-5 Y$ \\
\hline Start-Up New HSMS (PNL) & $M$ & & & & & & & & done under 101-5Y \\
\hline Dev Mechods for HSMS (PML) & y & & & & & & & & done under $101-5 y$ \\
\hline Physical Prop Methods Dev & M & & & & & & & & done under 103-sY \\
\hline Physical Modeling (PML) & $Y$ & & & & $x$ & & & & \\
\hline Gas Flow Modeling & $\varphi$ & & & & $x$ & & & & \\
\hline Thermal Behavior & $M$ & & & & & & & & complete under AN farm \\
\hline \multicolumn{10}{|l|}{ TS0133 close Usa/Resolve sI } \\
\hline Tech suppt USa/WL screening & $M$ & & & & & & & & done under $103-51$ \\
\hline Uso Database Report & H & & & & & & & & complete under AM farm \\
\hline Hazard Assessment & $Y$ & & $x$ & $x$ & & & & & \\
\hline Safety Documentation & $Y$ & & & $x$ & $x$ & & & & \\
\hline EAs & $Y$ & & & $x$ & $x$ & & & & \\
\hline Hydrogen Burn Anglysis & $Y$ & & & & $x$ & & & & \\
\hline ISB/Close Uso & $Y$ & & & & $x$ & $x$ & & & \\
\hline S1 Resolution & $\varphi$ & & & & & & $x$ & & after monitoring upgrds \\
\hline \multicolumn{10}{|l|}{ Ts0121 Monitoring Upgrades } \\
\hline Riser/Window Planning & $Y$ & & & & $x$ & & & & \\
\hline Gas Monitoring (SHMS) & $Y$ & & & & $x$ & & & & \\
\hline Repair Existing TCS & $Y$ & $x$ & & & & & & & \\
\hline MITs & $Y$ & & & & & $x$ & & & \\
\hline TMACS & $Y$ & & $x$ & & & & & & by Organic Program \\
\hline Surface Lavel & $Y$ & & & & & $x$ & & & \\
\hline
\end{tabular}


Table 6-1. Work Activities for the Flammable Gas Tank Safety Program.

\begin{tabular}{|c|c|c|c|c|c|c|c|c|c|}
\hline \multirow{2}{*}{ WORK JOS } & \multirow{2}{*}{ REQ } & \multicolumn{6}{|c|}{$\cdots \cdots$ MEEDED IM FISCAL YEAR $\cdots \ldots$} & \multirow{2}{*}{$\begin{array}{c}\text { JOB } \\
\text { COMPLETE }\end{array}$} & \multirow{2}{*}{ COMMENTS } \\
\hline & & 94 & 95 & 96 & 97 & 98 & 99 & & \\
\hline TV Camera & $M$ & & & & & & & & \\
\hline Ventilation & $Y$ & & & & & $x$ & & & \\
\hline Permitting/NEPA & $\boldsymbol{Y}$ & & & & & $x$ & & & \\
\hline Density Trees & M & & & & & & & & \\
\hline Lightning Protection & M & & & & & & & & \\
\hline Mise if Upgrades & M & & & & & & & & \\
\hline Equip Renovl/D ispos l/storage & $r$ & & & & & $x$ & & & \\
\hline \multicolumn{10}{|l|}{ Ps0122 mitigation } \\
\hline Technology Dev/Model ing & H & & & & & & & & mitigation not regd \\
\hline Mitigation Test & N & & & & & & & & 18 \\
\hline Design & N & & & & & & & & 18 \\
\hline SA/EA & M & & & & & & & & "18 \\
\hline Procure/Fab & $M$ & & & & & & & & "8 \\
\hline Window Hork/Install & $m$ & & & & & & & & 18 \\
\hline \multicolumn{10}{|c|}{ 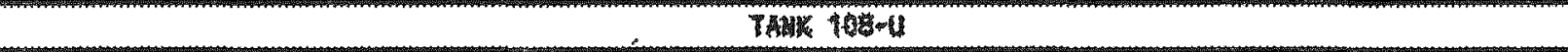 } \\
\hline \multicolumn{10}{|l|}{ Ts0103 Evaluate \& Define } \\
\hline Auger Sampling/Analysis & H & & & & & & & & erust doesn't trap gas \\
\hline Core Sampling/Analysis (N4) & $r$ & & & & $x$ & & & & \\
\hline Data interpretation & $y$ & & & & $\bar{x}$ & & & & \\
\hline Vapor sampling & $r$ & & & & $x$ & & & & \\
\hline Vapor Analysis w/HSMS (PNL) & $r$ & & & & $x$ & & & & \\
\hline In-Tankffield Work & $\gamma$ & & & & $x$ & & & & \\
\hline GRE Reports & N & & & & & & & & no gas release events \\
\hline Gas Analysis Reports & $r$ & & & & $x$ & & & & \\
\hline In-situ Gas Sampling & N & & & & & & & & dev under 104-AM \\
\hline Waste Behar Data Eval (PNL) & $\gamma$ & & & & $x$ & & & & \\
\hline \multicolumn{10}{|l|}{ TS0105 Technology for Eval } \\
\hline Radiolytic Mechanisms (AML) & 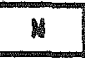 & & & & & & & & done under 101-5Y \\
\hline Chemical Mech (GIT/Other) & N & & & & & & & & not regd for SsTs \\
\hline Gas Generation (MHC/TBD) & N & & & & & & & & not regd for SSTs \\
\hline Synthetic studies (PNL) & $M$ & & & & & & & & not regd for SSTs \\
\hline Org Methods Dev (PNL) & $M$ & & & & & & & & done under $103-5 Y$ \\
\hline Start-Up Nes HSMS (PNL) & N & & & & & & & & done under $101.5 Y$ \\
\hline Dev Methods for HSMS (PNL) & N & & & & & & & & done under $101-5 \gamma$ \\
\hline Physical Prop Mechods Dev & M & & & & & & & & done under $103.5 Y$ \\
\hline Physical Model ing (PNL) & $\gamma$ & & & & $x$ & & & & \\
\hline Gas flow Hodel ing & $r$ & & & & $x$ & & & & \\
\hline Thermal Behavior & $M$ & & & & & & & & complete under AN farm \\
\hline \multicolumn{10}{|l|}{ TS0133 Close USQ/Resolve SI } \\
\hline Tech Suppt USQ/WL Sereening & M & & & & & & & & done under $103-5 Y$ \\
\hline USQ Database Report & $M$ & & & & & & & & complese under AN farm \\
\hline Hazard Assessment & $\gamma$ & & & $x$ & $x$ & & & & \\
\hline Safety Documentation & $r$ & & & $x$ & $x$ & & & & \\
\hline
\end{tabular}


Table 6-1. Work Activities for the Flammable Gas Tank Safety Program.

\begin{tabular}{|c|c|c|c|c|c|c|c|c|c|}
\hline \multirow{2}{*}{ WORK JOB } & \multirow{2}{*}{ RECO } & \multicolumn{6}{|c|}{$\cdots \infty$ MEEDED IN FISCAL VEAR $\cdots \cdots$} & \multirow{2}{*}{$\begin{array}{c}108 \\
\text { COMPLETE }\end{array}$} & \multirow{2}{*}{ COMMENTS } \\
\hline & & 94 & 95 & 86 & 97 & 98 & 89 & & \\
\hline EAs & $Y$ & & & $x$ & $x$ & & & & \\
\hline Hydrogen Burn Analysis & $Y$ & & & & & $x$ & & & \\
\hline Is8/Close Uso & $\gamma$ & & & & $x$ & $x$ & & & \\
\hline S1 Resolution & $\gamma$ & & & & & & $x$ & & after monitoring upgrds \\
\hline \multicolumn{10}{|l|}{ Is0121 Monitoring Upgrades } \\
\hline Riser/vindow Planning & $\gamma$ & & & & $x$ & & & & \\
\hline Gas Monitoring (SHMS) & $\gamma$ & & & & $x$ & & & & \\
\hline Repair Existing TCs & $Y$ & $x$ & & & & & & & \\
\hline MITS & $Y$ & & & & & $x$ & & & \\
\hline TMACS & $\nabla$ & & $x$ & & & & & & by Organic Program \\
\hline Surface Level & $\gamma$ & & & & & $x$ & & & \\
\hline TV Camera & M & & & & & & & & \\
\hline Ventil ation & $\checkmark$ & & & & & & $x$ & & \\
\hline Permi tring/MEPA & 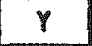 & & & & & & $x$ & & \\
\hline Density Trees & M & & & & & & & & \\
\hline Lightring Protection & $*$ & & & & & & & & \\
\hline Misc if Upgrades & $M$ & & & & & & & & \\
\hline Equip Removl/Dispos //Storage & $\gamma$ & & & & & $x$ & & & \\
\hline \multicolumn{10}{|l|}{ Ts0122 Mitigation } \\
\hline Technology Dev/Model ing & $N$ & & & & & & & & mitigation not reqd \\
\hline Mitigation Test & $n$ & & & & & & & & 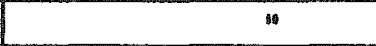 \\
\hline Design & M & & & & & & & & 18 \\
\hline SA/EA & 到 & & & & & & & & " \\
\hline Procure/Fab & $M$ & & & & & & & & 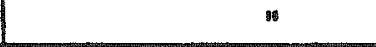 \\
\hline Window Work/Install & $N$ & & & & & & & & 18 \\
\hline \multicolumn{10}{|c|}{ THAX } \\
\hline \multicolumn{10}{|l|}{ Tsolos Evaluate \& Define } \\
\hline Auger Sampling/Analys is & $M$ & & & & & & & & erust doesn't trap gas \\
\hline Core Sampling/Analysis (Nh) & $Y$ & & & & $x$ & & & & \\
\hline Data Interprecation & $\gamma$ & & & & $x$ & & & & \\
\hline Vapor sampling & $\varphi$ & & & & $x$ & & & & \\
\hline Vapor Analysis w/HSAS (PNL) & $\varphi$ & & & & $x$ & & & & \\
\hline In-Tank/Field Work & $Y$ & & & & $x$ & & & & \\
\hline GRE Reports & N & & & & & & & & no gas release events \\
\hline Gas Analys is Reports & $Y$ & & & & $x$ & & & & \\
\hline In-Situ Gas Sampling & H & & & & & & & & dev under $104-\mathrm{AM}$ \\
\hline Waste Behay Data Eval (PNL) & $Y$ & & & & $x$ & & & & \\
\hline \multicolumn{10}{|l|}{ Ts0105 fechnology for Eval } \\
\hline Radiolytic Mechanisms (AML) & N & & & & & & & & done under 101-5Y \\
\hline Chemical Mech (GIT/Other) & N & & & & & & & & not reqd for ssts \\
\hline Gas Generation (WHC/TBO) & H & & & & & & & & not reqd for SSTs \\
\hline Synthetic studies (PML) & N & & & & & & & & not regd for SSTs \\
\hline Org Methods Dev (PML) & H & & & & & & & & cone under $103-5 Y$ \\
\hline
\end{tabular}


Table 6-1. Work Activities for the Flammable Gas Tank Safety Program.

\begin{tabular}{|c|c|c|c|c|c|c|c|c|c|}
\hline \multirow{2}{*}{ WORK JOB } & \multirow{2}{*}{ REOD } & \multicolumn{6}{|c|}{ \#-.. NEEDED IN FISCAL YEAR $\cdots \infty$} & \multirow{2}{*}{$\begin{array}{c}\text { JOS } \\
\text { COMPLETE }\end{array}$} & \multirow{2}{*}{ COMMENTS } \\
\hline & & 94 & 95 & 96 & 97 & 88 & 99 & & \\
\hline Start-Up New HSMS (PML) & N & & & & & & & & done under 101-5Y \\
\hline Dev Methods for MSMS (PNL) & H & & & & & & & & don under $101.5 Y$ \\
\hline Physical Prop Methods Dev & 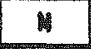 & & & & & & & & done under 103-5Y \\
\hline Physical Modeling (PML) & $Y$ & & & & $x$ & & & & \\
\hline Gas flom Modeling & 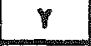 & & & & $x$ & & & & \\
\hline Thermal Behavior & H & & & & & & & & complete under AM farm \\
\hline \multicolumn{10}{|l|}{ Tso133 close usa/Resolve $\$$} \\
\hline Tech Suppt USQ/WL Screening & N & & & & & & & & done under 103-5y \\
\hline Uso Database Report & H & & & & & & & & compl under AM farm \\
\hline Hazard Assessment & $\nabla$ & & & $x$ & $x$ & & & & \\
\hline Safety Documentation & $\gamma$ & & & & $x$ & & & & \\
\hline EAs & $\gamma$ & & & & $x$ & & & & \\
\hline Hydrogen Burn Anslysis & $\nabla$ & & & & & $x$ & & & \\
\hline Is8/Close Usa & $Y$ & & & & & $x$ & & & \\
\hline S\& Resolution & $\varphi$ & & & & & & $x$ & & after monitoring upgrds \\
\hline \multicolumn{10}{|l|}{ TS0121 Monitoring Upgrades } \\
\hline Riser/window Planning & $\gamma$ & & & & $x$ & & & & \\
\hline Gas Monitoring (SHMS) & $\varphi$ & & & & $x$ & & & & \\
\hline Repsir Existing TCs & $Y$ & $x$ & & & & & & & \\
\hline MITs & $Y$ & & & & & $x$ & & & \\
\hline TMACS & $\varphi$ & & $x$ & & & & & & by Organic Program \\
\hline Surface Level & $Y$ & & & & & $x$ & & & \\
\hline TV Camera & $M$ & & & & & & & & \\
\hline Ventilation & $Y$ & & & & & & $x$ & & \\
\hline Permit tTing/NEPA & $Y$ & & & & & & $x$ & & \\
\hline Density Trees & H & & & & & & & & \\
\hline Lightning Protection & 4 & & & & & & & & \\
\hline Mise If Upgrades & M & & & & & & & & \\
\hline Equip Renovl/0isposl/storage & $Y$ & & & & & $x$ & & & \\
\hline \multicolumn{10}{|l|}{ Ts0122 Mitigation } \\
\hline Technology Dev/Model ing & $M$ & & & & & & & & mitigation not regd \\
\hline Mitigation Test & N & & & & & & & & 18 \\
\hline Design & 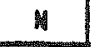 & & & & & & & & : \\
\hline SA/EA & $M$ & & & & & & & & 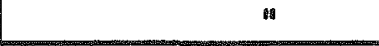 \\
\hline Procure/Fab & M & & & & & & & & "9 \\
\hline Window Work/Install & N & & & & & & & & sis \\
\hline & $\therefore$ & & & TAMK & $112+5$ & & & & \\
\hline \multicolumn{10}{|l|}{ IS0103 Evaluat \& Define } \\
\hline Auger Sampling/Analys is & $M$ & & & & & & & & crust doesn't trap gas \\
\hline Core Sampling/Analys is (NA) & $Y$ & & & & $x$ & & & & \\
\hline Data interpretation & $Y$ & & & & $x$ & & & & \\
\hline Vapor Sampling & 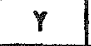 & & & & $x$ & & & & \\
\hline Vapor Analysis w/HSMS (PML) & 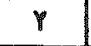 & & & & $x$ & & & & \\
\hline
\end{tabular}


Table 6-1. Work Activities for the Flammable Gas Tank Safety Program.

\begin{tabular}{|c|c|c|c|c|c|c|c|c|c|}
\hline \multirow{2}{*}{ WORK JOS } & \multirow{2}{*}{ MEQO } & \multicolumn{6}{|c|}{ 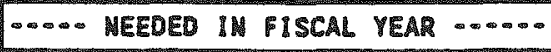 } & \multirow{2}{*}{$\begin{array}{c}\text { JOS } \\
\text { COAPLETE }\end{array}$} & \multirow{2}{*}{ COMMENTS } \\
\hline & & 96 & 85 & 96 & 97 & 98 & 99 & & \\
\hline In-Tank/Field Work & $\varphi$ & & & & $x$ & & & & \\
\hline GRE Reports & H & & & & & & & & no gas release events \\
\hline Gas Analys is Reports & $\gamma$ & & & & $x$ & & & & \\
\hline In-Situ Gas Sampling & W & & & & & & & & dev under 104-AM \\
\hline Haste Behav Datr Eval (PML) & 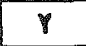 & & & & $x$ & & & & \\
\hline \multicolumn{10}{|l|}{ Iso105 Technology for Eval } \\
\hline Radiolytic Mechanisms (ANL) & M & & & & & & & & done under $101-5 y$ \\
\hline Chermical Mech (GIT/Other) & * & & & & & & & & not regd for SSTS \\
\hline Gas Generation (HHC/TEO) & M & & & & & & & & not regd for SSTs \\
\hline Symthetic studies (PNL) & H & & & & & & & & not regd for SSTs \\
\hline Org Methods Dev (PML) & 觟 & & & & & & & & done under $103-5 Y$ \\
\hline Start-Up MeW HSIS (PML) & $\mathrm{M}$ & & & & & & & & done under 101-5Y \\
\hline Dev Methods for HSMS (PNL) & 1 & & & & & & & & done under 101-\$Y \\
\hline Physical Prop methods Dev & $M$ & & & & & & & & done under $103-5 y$ \\
\hline Physical Modeling (PML) & $\gamma$ & & & & $x$ & & & & \\
\hline Gas Flow Modeling & $r$ & & & & $x$ & & & & \\
\hline Thermal Behavior & N & & & & & & & & complete under AN farm \\
\hline \multicolumn{10}{|l|}{ Tso133 Close Usa/Resolve SI } \\
\hline Tech Suppt Usa/WL Screening & M & & & & & & & & done under 103-5Y \\
\hline USa Database Report & $M$ & & & & & & & & complete under AM farm \\
\hline Hazard Assessment & 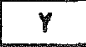 & & & $x$ & $x$ & & & & \\
\hline Safety Documentation & $\gamma$ & & & & $x$ & & & & \\
\hline EAS & $\gamma$ & & & & $x$ & & & & \\
\hline Hydrogen Burn Analysis & $\gamma$ & & & & & $x$ & & & \\
\hline Iso/close Usa & $Y$ & & & & & $x$ & & & \\
\hline SI Resolution & $\varphi$ & & & & & & $x$ & & after monitoring upgrds \\
\hline \multicolumn{10}{|l|}{ TSO121 Monitoring Upgrades } \\
\hline Riser/Window Plaming & $p$ & & & & $x$ & & & & \\
\hline Gas Monitoring (SHMS) & $Y$ & & & & $x$ & & & & \\
\hline Repair Existing TCS & $\gamma$ & $x$ & & & & & & & \\
\hline MITS & $\varphi$ & & & & & $x$ & & & \\
\hline TMACS & $\Upsilon$ & & $x$ & & & & & & by organic Program \\
\hline Surface Level & $\gamma$ & & & & & $x$ & & & \\
\hline TV Camera & $N$ & & & & & & & & \\
\hline Ventilation & $\gamma$ & & & & & $x$ & & & \\
\hline Permitting/NEPA & $\gamma$ & & & & & $x$ & & & \\
\hline Density Trees & M & & & & & & & & \\
\hline Lightning Protection & $M$ & & & & & & & & \\
\hline Misc TF Upgrades & N & & & & & & & & \\
\hline Equip Removl/Dispos//Storage & $Y$ & & & & & $x$ & & & \\
\hline \multicolumn{10}{|l|}{ TSOI22 mitigation } \\
\hline Technology Dev/Model ing & $M$ & & & & & & & & mitigation not regd \\
\hline Mitigation Test & M & & & & & & & & a \\
\hline
\end{tabular}


Table 6-1. Work Activities for the Flammable Gas Tank Safety Program.

\begin{tabular}{|c|c|c|c|c|c|c|c|c|c|}
\hline \multirow{2}{*}{ HORK JOB } & \multirow{2}{*}{ Reoo } & \multicolumn{6}{|c|}{$\ldots-\infty$ NEEDED IN FISCAL YEAR $\ldots \ldots$} & \multirow{2}{*}{$\begin{array}{c}\text { JOS } \\
\text { COMPLETE }\end{array}$} & \multirow{2}{*}{ COMMENTS } \\
\hline & & 84 & 95 & 96 & 97 & 98 & 99 & & \\
\hline Design & $M$ & & & & & & & & a8 \\
\hline SA/EA & 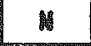 & & & & & & & & 88 \\
\hline Procurelfab & H & & & & & & & & 88 \\
\hline Window Work/Instal! & M & & & & & & & & 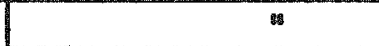 \\
\hline \multicolumn{10}{|c|}{ THXX +054} \\
\hline \multicolumn{10}{|l|}{ Ts0103 Evaluate Define } \\
\hline Auger Sempling/Analysis & M & & & & & & & & crust doesn't trap gas \\
\hline Core Sampling/Analysis (N4) & $Y$ & & & & $x$ & $x$ & & & \\
\hline Data Interpretation & $Y$ & & & & $x$ & $x$ & & & \\
\hline Vapor Sampling & 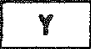 & & & & $x$ & & & & \\
\hline Vopor Anelysis H/HSMS (PML) & $Y$ & & & & $x$ & $x$ & & & \\
\hline In-Tank/field Hork & $Y$ & & & & $x$ & $x$ & & & \\
\hline GRE Reports & 解 & & & & & & & & no gas release events \\
\hline Gas And lysis Reports & $Y$ & & & & $x$ & $x$ & & & \\
\hline In-51 tu Gas Sampling & 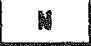 & & & & & & & & dev under $104-\mathrm{AM}$ \\
\hline Waste Behav Data Eval (PML) & $\vartheta$ & & & . & $x$ & $x$ & & & \\
\hline \multicolumn{10}{|l|}{ Tsolos Technology for Eva! } \\
\hline Radiolytic Mechanisms (AML) & n & & & & & & & & done under 101-5Y \\
\hline Chemical Mech (GIT/Other) & $M$ & & & & & & & & not regd for SSTs \\
\hline Gas Generation (WHC/TBO) & $M$ & & & & & & & & not regd for SSTs \\
\hline Synthetic studies (PNL) & $M$ & & & & & & & & not regd for SSTs \\
\hline Org Methods Der (PHL) & * & & & & & & & & done under 103-sy \\
\hline Start-UP NEN MSMS (PML) & H & & & & & & & & done under 101-5Y \\
\hline Dev Methods for HSMS (PML) & M & & & & & & & & done under $101 \cdot \$ Y$ \\
\hline Physical Prop Methods Dey & M & & & & & & & & done under 103-5y \\
\hline Physical Modeling (PML) & $y$ & & & & $x$ & & & & \\
\hline Gas Flow Modeling & $Y$ & & & & $x$ & & & & \\
\hline Thermal Behavior & $M$ & & & & & & & & complete under AN farm \\
\hline \multicolumn{10}{|l|}{ TSO133 Close USA/Resolve SI } \\
\hline Tech Suppt USa/WL Screening & N & & & & & & & & done under 103-sy \\
\hline USQ Database Report & N & & & & & & & & complete under AM farm \\
\hline Hazard Assessment & $\gamma$ & & & $x$ & $x$ & & & & \\
\hline Safety Documentation & $Y$ & & & & $x$ & & & & \\
\hline EAs & $Y$ & & & & $x$ & & & & \\
\hline Hydrogen Burn Analysis & $Y$ & & & & & $x$ & & & \\
\hline Iss/Close use & $Y$ & & & & & $x$ & & & \\
\hline 51 Resolution & $Y$ & & & & & & $x$ & & after monitoring upgros \\
\hline \multicolumn{10}{|l|}{ Ts0121 Monitoring Upgrades } \\
\hline Riser/Window Planning & $\gamma$ & & & & $x$ & & & & \\
\hline Gas Monitoring (SHMS) & $\gamma$ & & & & $x$ & & & & \\
\hline Repair Existing TCs & $Y$ & $x$ & & & & & & & \\
\hline MITs & $Y$ & & & & & $x$ & & & \\
\hline TMACS & $Y$ & & $x$ & & & & & & by Organic Program \\
\hline
\end{tabular}


Table 6-1. Work Activities for the Flammable Gas Tank Safety Program.

\begin{tabular}{|c|c|c|c|c|c|c|c|c|c|}
\hline \multirow{2}{*}{ HORK JOS } & \multirow{2}{*}{ REOO } & \multicolumn{6}{|c|}{$\cdots \cdots$ MEEDED IN FISCAL YEAR $\cdots \cdots$} & \multirow{2}{*}{$\stackrel{108}{\text { COMPLETE }}$} & \multirow{2}{*}{ COMMENTS } \\
\hline & & 94 & 95 & 96 & 97 & 98 & 98 & & \\
\hline Surface Level & $Y$ & & & & & $x$ & & & \\
\hline TV Camera & H & & & & & & & & \\
\hline Ventilation & $Y$ & & & & & & $x$ & & \\
\hline Permitting/NEPA & $\gamma$ & & & & & & $x$ & & \\
\hline Density Trees & H & & & & & & & & \\
\hline Lightning Protection & 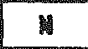 & & & & & & & & \\
\hline Mís if Upgrades & 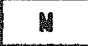 & & & & & & & & \\
\hline Equip Removl/D ispos//storage & $\checkmark$ & & & & & $x$ & & & \\
\hline \multicolumn{10}{|l|}{ Ts0122 Mitigarion } \\
\hline Technology Dev/Model ing & H & & & & & & & & mitigation not reqd \\
\hline Mitigation Test & (1) & & & & & & & & B \\
\hline Design & N & & & & & & & & "s \\
\hline SA/EA & 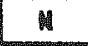 & & & & & & & & 8 \\
\hline Procure/Fab & w & & & & & & & & "8 \\
\hline Window Hork/Install & M & & & & & & & & ) \\
\hline \multicolumn{10}{|c|}{ PMUK $190-5$} \\
\hline \multicolumn{10}{|l|}{ Ts0103 Evaluate Define } \\
\hline Auger Sampling/Analysis & M & & & & & & & & crust doesn' trap gas \\
\hline Core Sampling/Analys is (N4) & $Y$ & & & & $x$ & $x$ & & & \\
\hline Data Interpretation & $Y$ & & & & $x$ & $x$ & & & \\
\hline Vapor Sanpl ing & $Y$ & & & & $x$ & & & & \\
\hline Vapor Analysis w/HSMS (PML) & $Y$ & & & & $x$ & $x$ & & & \\
\hline In-Tank/field Hork & $Y$ & & & & $x$ & $x$ & & & \\
\hline GRE Reports & H & & & & & & & & no gas release events \\
\hline Gas Analysis Reports & $Y$ & & & & $x$ & $x$ & & & \\
\hline In-situ Gas sampling & 1 & & & & & & & & Idev under 104-AM \\
\hline Waste Behav Data Eval (PML) & $Y$ & & & & $x$ & $x$ & & & \\
\hline \multicolumn{10}{|l|}{ T50105 Technology for Eval } \\
\hline Radiolytic Mechanisms (AML) & $\mathrm{N}$ & & & & & & & & done under 101-5Y \\
\hline Chemical Mech (GIT/Other) & $H$ & & & & & & & & not regd for SSTs \\
\hline Gas Generation (HHC/TBD) & $M$ & & & & & & & & not regd for SSTS \\
\hline Synthetic studies (PNL) & H & & & & & & & & not regd for S\$TS \\
\hline Org Methods Dev (PNL) & $M$ & & & & & & & & done under 103-SY \\
\hline Start-UP New HSMS (PML) & $M$ & & & & & & & & dorie under 101-5Y \\
\hline Dev Methods for HSMS (PML) & H & & & & & & & & done under 101-5Y \\
\hline Physical Prop Methods Dev & H & & & & & & & & done under 103-5Y \\
\hline Physical Modeling (PNL) & $\gamma$ & & & & $x$ & & & & \\
\hline Gas Flow Modeling & $Y$ & & & & $x$ & & & & \\
\hline Thermol Behavior & N & & & & & & & & Complete under AM farm \\
\hline \multicolumn{10}{|l|}{ TS0133 close USQ/Resolve SI } \\
\hline Tech Suppt Usa/hl Screening & H & & & & & & & & done under 103-5Y \\
\hline USQ Database Report: & $M$ & & & & & & & & Complete under AM farm \\
\hline Hazard Assessment & $\varphi$ & & & & $x$ & & & & \\
\hline
\end{tabular}


Table 6-1. Work Activities for the Flammable Gas Tank Safety Program.

\begin{tabular}{|c|c|c|c|c|c|c|c|c|c|}
\hline \multirow{2}{*}{ HORT JOS } & \multirow{2}{*}{ REOQ } & \multicolumn{6}{|c|}{ 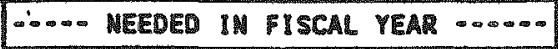 } & \multirow{2}{*}{$\begin{array}{c}\text { JOS } \\
\text { COAPLETE }\end{array}$} & \multirow{2}{*}{ COAMENTS } \\
\hline & & 94 & 95 & 96 & 97 & 98 & 99 & & \\
\hline Safety Docunentation & $Y$ & & & & $x$ & $x$ & & & \\
\hline EAS & $\gamma$ & & & & $x$ & & & & \\
\hline Hydrogen Burn Analysis & 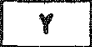 & & & & & $x$ & & & \\
\hline ISB/Close USO & $Y$ & & & & & $x$ & & & \\
\hline S1 Resolution & $Y$ & & & & & & $x$ & & after monitoring upgrds \\
\hline \multicolumn{10}{|l|}{ TSO121 Monitoring Upgrades } \\
\hline Riser/Window Planning & $\checkmark$ & & & & $x$ & & & & \\
\hline Gas Monitoring (SHMS) & $Y$ & & & & $x$ & & & & \\
\hline Repair Existing TCs & $\gamma$ & $x$ & & & & & & & \\
\hline MITs & T & & & & & $x$ & & & \\
\hline IMACS & $Y$ & & & & & & & $Y$ & by Feck Progran \\
\hline Surface Level & $Y$ & & & & & $x$ & & & \\
\hline TV Camera & H & & & & & & & & \\
\hline Ventilation & $\gamma$ & & & & & & $x$ & & \\
\hline Permitting/HEPA & $\gamma$ & & & & & & $x$ & & \\
\hline Density Traes & * & & & & & & & & \\
\hline Lightning Protection & $M$ & & & & & & & & \\
\hline Mise TF Upgrades & 異 & & & & & & & & \\
\hline Equip Renovl/Dispos l/storage & $Y$ & & & & & $x$ & & & \\
\hline \multicolumn{10}{|l|}{ T50122 Mitigation } \\
\hline Technology Dev/Model ing & H & & & & & & & & mitigation not regd \\
\hline Mitigation Test & H & & & & & & & & 80 \\
\hline Design & 4 & & & & & & & & $"$ \\
\hline SA/EA & H & & & & & & & & 8日 \\
\hline Procure/fab & H & & & & & & & & 89 \\
\hline Hindow Work/Install & $N$ & & & & & & & & " \\
\hline \multicolumn{10}{|c|}{ TANK } \\
\hline \multicolumn{10}{|l|}{ TS0103 Evaluat Define } \\
\hline Auger Sampling/Analys is & N & & & & & & & & Crust doesn't trap gas \\
\hline Core Sempling/Analys is (N4) & $Y$ & & & & $x$ & $x$ & & & \\
\hline Data Interpretation & $Y$ & & & & & $x$ & & & \\
\hline Vapor Sempling & $Y$ & & & & $x$ & & & & \\
\hline Vapor Analys is w/HSMS (PML) & $Y$ & & & & & $x$ & & & \\
\hline In-Tank/Field Work & $Y$ & & & & & $x$ & & & \\
\hline GRE Reports & H & & & & & & & & no gas release events \\
\hline Gas Analysis Reports & $\gamma$ & & & & & $x$ & & & \\
\hline In-Situ Gas Sampling & $H$ & & & & & & & & dey under 104-AN \\
\hline Waste Behav Data Eval (PNL) & $Y$ & & & & & $x$ & & & \\
\hline \multicolumn{10}{|l|}{ Ts0105 Technology for Eval } \\
\hline Radiolytic Mechanisms (ANL) & $N$ & & & & & & & & done under 101-sy \\
\hline Chemical Mech (GIT/Other) & * & & & & & & & & not read for SSTs \\
\hline Gas Generation (WHC/TBD) & H & & & & & & & & not regd for SSTS \\
\hline Synthetic studies (PNL) & N & & & & & & & & not regd for SSTs \\
\hline
\end{tabular}


Table 6-1. Work Activities for the Flammable Gas Tank Safety Program.

\begin{tabular}{|c|c|c|c|c|c|c|c|c|c|}
\hline \multirow{2}{*}{ MORK JOS } & \multirow{2}{*}{ REDOO } & \multicolumn{6}{|c|}{-a NEEDEO IV FISCAL YEAR $\cdots \cdots$} & \multirow{2}{*}{$\begin{array}{l}\text { JOS } \\
\text { COMPLETE }\end{array}$} & \multirow{2}{*}{ COMHEMTS } \\
\hline & & 94 & 85 & 96 & 97 & 98 & 89 & & \\
\hline Org Methods DeV (PNL) & 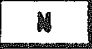 & & & & & & & & done under 103-5y \\
\hline Start-UP NEN HSMS (PNL) & M & & & & & & & & done under 101-5Y \\
\hline Dev Methods for HSMS (PML) & $M$ & & & & & & & & done under 101-5Y \\
\hline Physical Prop Methods Dev & \# & & & & & & & & done under 103-\$Y \\
\hline Physical Modeling (PNL) & $\gamma$ & & & & $x$ & & & & \\
\hline Ges low Model ing & 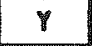 & & & & $x$ & & & & \\
\hline Thermal Behavior & H & & & & & & & & complete under AN farm \\
\hline \multicolumn{10}{|l|}{ Ts0133 Close usa/Resolve sI } \\
\hline Tech Suppt Usa/ML Screening & $M$ & & & & & & & & done under $103-5 Y$ \\
\hline Usa Database Report & W & & & & & & & & compl ere under AN farm \\
\hline Hazard Assessment & $\gamma$ & & & & $x$ & & & & \\
\hline Safety Documentation & $Y$ & & & & $x$ & $x$ & & & \\
\hline EAs & $Y$ & & & & $x$ & & & & \\
\hline Mydrogen Burn Analysis & $\gamma$ & & & & & $x$ & & & \\
\hline 15B/Close Usa & $\gamma$ & & & & & $x$ & & & \\
\hline S1 Resolution & $\varphi$ & & & & & & $x$ & & after monitoring upgrds \\
\hline \multicolumn{10}{|l|}{ TSO121 Monitoring Upgrades } \\
\hline Riser/Window Planning & $y$ & & & & & $x$ & & & \\
\hline Gas Monitoring (sHMS) & $\gamma$ & & & & & $x$ & & & \\
\hline Repair Existing TCs & $\gamma$ & $x$ & & & & & & & \\
\hline MITs & $Y$ & & & & & & $x$ & & \\
\hline TMACS & 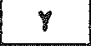 & & $x$ & & & & & & by Organic Program \\
\hline Surface Level & $\vartheta$ & & & & & & $x$ & & \\
\hline TV Camera & 触 & & & & & & & & \\
\hline Ventilation & $Y$ & & & & & $x$ & & & \\
\hline Permitting/NEPA & $Y$ & & & & & $x$ & & & \\
\hline Density Trees & $*$ & & & & & & & & \\
\hline Lightning Protection & H & & & & & & & & \\
\hline Misc If Upgrades & 4 & & & & & & & & \\
\hline Equip Removl/o ispos//Storage & $\varphi$ & & & & & $x$ & & & \\
\hline \multicolumn{10}{|l|}{ Ts0122 mitigation } \\
\hline Technology Dev/Model ing & 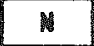 & & & & & & & & mitigation not regd \\
\hline Mitigation Test & N & & & & & & & & is \\
\hline Design & $M$ & & & & & & & & 1" \\
\hline SA/EA & N & & & & & & & & 18 \\
\hline Procure/Fab & H & & & & & & & & "s \\
\hline Window Work/Install & 为 & & & & & & & & 8 \\
\hline & & & & 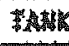 & 803 & & & & \\
\hline \multicolumn{10}{|l|}{ Ts0103 Evaluate \& Detine } \\
\hline Auger Sampl ing/Analys is & $M$ & & & & & & & & crust doesn't trap gas \\
\hline Core Sampling/Analysis (N4) & $Y$ & & & & $x$ & $x$ & & & \\
\hline Data Interpretation & $\gamma$ & & & & & $x$ & & & \\
\hline Yapor Sempl ing & $Y$ & & & & $x$ & & & & \\
\hline
\end{tabular}


Table 6-1. Work Activities for the Flammable Gas Tank Safety Program.

\begin{tabular}{|c|c|c|c|c|c|c|c|c|c|}
\hline \multirow{2}{*}{ HORK LOB } & \multirow{2}{*}{ REO0 } & \multicolumn{6}{|c|}{$\cdots \infty-N E E D E D$ IN FISCAL YEAR $\cdots \infty \cdots$} & \multirow{2}{*}{$\begin{array}{c}\text { JOR } \\
\text { COMPLETE }\end{array}$} & \multirow{2}{*}{ COMMEMTS } \\
\hline & & 94 & 95 & 96 & 87 & 98 & 99 & & \\
\hline Vapor Analys is w/MSAS (PHL) & $Y$ & & & & & $x$ & & & \\
\hline In-Tank/Pield Work & $\gamma$ & & & & & $x$ & & & \\
\hline GRE Reports & $M$ & & & & & & & & no gas release vents \\
\hline Gas Analysis Reports & $Y$ & & & & & $x$ & & & \\
\hline In-sicu Gas Sampling & W & & & & & & & & dev under 104-AM \\
\hline Waste Behav Data Eval (PML) & $\varphi$ & & & & & $x$ & & & \\
\hline
\end{tabular}


Table 6-1. Work Activities for the Flammable Gas Tank Safety Program.

\begin{tabular}{|c|c|c|c|c|c|c|c|c|c|}
\hline \multirow{2}{*}{ MORK JOB } & \multirow{2}{*}{ REQO } & \multicolumn{6}{|c|}{$\ldots \ldots$ MEEDED IM FISCAL YEAR $\ldots \ldots$} & \multirow{2}{*}{$\begin{array}{c}\text { JOB } \\
\text { COMPLETE }\end{array}$} & \multirow{2}{*}{ COMMENTS } \\
\hline & & 94 & 95 & 96 & 97 & 98 & 99 & & \\
\hline \multicolumn{10}{|l|}{ TS0105 Technol ogy for Eval } \\
\hline Radiolytic Mechanisms (AML) & $M$ & & & & & & & & done under 101-5Y \\
\hline Chemical Mech (GIT/Other) & M & & & & & & & & not regd for SSTS \\
\hline Gas Generation (WHC/TBD) & 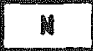 & & & & & & & & not reqd for Ssis \\
\hline Synthetic studies (PNL) & 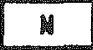 & & & & & & & & not regd for SSTs \\
\hline Org Methods Dev (PNL) & $M$ & & & & & & & & done under $103-5 y$ \\
\hline Start-Up New HSMS (PNL) & 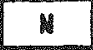 & & & & & & & & done under $101-5 y$ \\
\hline Dev Methods for HSMS (PML) & $M$ & & & & & & & & done under 101-sy \\
\hline Physical Prop Methads Dev & $M$ & & & & & & & & done under $103-5 Y$ \\
\hline Physical Model ing (PNL) & $Y$ & & & & $x$ & & & & \\
\hline Gas Flow Modeling & $r$ & & & & $x$ & & & & \\
\hline Thermal Behavior & M & & & & & & & & complete under AM farm \\
\hline \multicolumn{10}{|l|}{ IS0133 close uSQ/Resolve \$1 } \\
\hline Tech Suppt USQ/WL Sereening & $M$ & & & & & & & & done under $103-5 y$ \\
\hline USQ Database Report & N & & & & & & & & complete under AM farm \\
\hline Mazard Assessment & $\gamma$ & & & & $x$ & & & & \\
\hline Safety Documentation & $Y$ & & & & $x$ & $x$ & & & \\
\hline EAs & $Y$ & & & & $x$ & & & & \\
\hline Hydrogen Burn Analysis & $Y$ & & & & & $x$ & & & \\
\hline IsB/Close usa & $r$ & & & & & $x$ & & & \\
\hline SI Resolution & $\gamma$ & & & & & & $x$ & & after monitoring upgrds \\
\hline \multicolumn{10}{|l|}{ TS0121 Monitoring Upgrades } \\
\hline Riser/Window Plaming & $y$ & & & & & $x$ & & & \\
\hline Gas Monitoring (SHMS) & $Y$ & & & & & $x$ & & & \\
\hline Repair Existing TCs & $\gamma$ & $x$ & & & & & & & \\
\hline MITs & $Y$ & & & & & & $x$ & & \\
\hline TMACS & $Y$ & & $x$ & & & & & & by Organic Program \\
\hline Surface Level & $r$ & & & & & & $x$ & & \\
\hline TV Camera & N & & & & & & & & \\
\hline Ventilation & $\gamma$ & & & & & $x$ & & & \\
\hline Parmitting/NEPA & $Y$ & & & & & $x$ & & & \\
\hline Density Trees & N & & & & & & & & \\
\hline Lightning Protection & $M$ & & & & & & & & \\
\hline Misc TF Upgrades & $M$ & & & & & & & & \\
\hline Equip Renovl/D isposl/Storage & $Y$ & & & & & $x$ & & & \\
\hline \multicolumn{10}{|l|}{ TS0122 Mitigation } \\
\hline Technology Dev/Model ing & $M$ & & & & & & & & mitigation not reqd \\
\hline Mitigation Test & N & & & & & & & & 18 \\
\hline Design & $M$ & & & & & & & & "1 \\
\hline SA/EA & $M$ & & & & & & & & s" \\
\hline Procure/Fab & $N$ & & & & & & & & 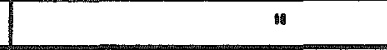 \\
\hline Window Work/Install & M & & & & & & & & "1" \\
\hline
\end{tabular}


Table 6-1. Work Activities for the Flammable Gas Tank Safety Program.

\begin{tabular}{|c|c|c|c|c|c|c|c|c|c|}
\hline \multirow{2}{*}{ MORK JOS } & \multirow{2}{*}{ REDO } & \multicolumn{4}{|c|}{-...- NEEDED IH FISCAL } & \multicolumn{2}{|c|}{ YEAR $\cdots \cdots$} & \multirow{2}{*}{\begin{tabular}{c|} 
JOB \\
COMPLETE
\end{tabular}} & \multirow{2}{*}{ COMMENTS } \\
\hline & & 94 & 95 & 96 & 97 & 98 & 99 & & \\
\hline \multicolumn{10}{|l|}{ IS0103 Evaluate \& Define } \\
\hline Auger Sampling/Analysis & $M$ & & & & & & & & crust doesn't trap gas \\
\hline Coro Sampling/Analysis (M4) & $Y$ & & & & $x$ & $x$ & & & \\
\hline Data Interpretation & $\gamma$ & & & & & $x$ & & & \\
\hline Vapor Sampling & $\gamma$ & & & & $x$ & & & & \\
\hline Vapor Analysis w/HSMS (PNL) & $y$ & & & & & $x$ & & & \\
\hline In-Tank/Field Work & $Y$ & & & & & $x$ & & & \\
\hline GRE Reports & $m$ & & & & & & & & no gas release events \\
\hline Gas Analysis Reports & $\gamma$ & & & & & $\bar{x}$ & & & \\
\hline In-situ Gas Sempling & N & & & & & & & & dev under 104-AM \\
\hline Waste Behar Dota Eval (PML) & $\gamma$ & & & & & $x$ & & & \\
\hline \multicolumn{10}{|l|}{ Tso105 Technology for Eval } \\
\hline Radiolyeic Mechanisms (AML) & $M$ & & & & & & & & done under $101-5 Y$ \\
\hline Chemical Mech (GlT/Other) & w & & & & & & & & not regd for 5sts \\
\hline Gas Generation (WHC/TBD) & $M$ & & & & & & & & not read for SSTs \\
\hline Synthetic studies (PNL) & M & & & & & & & & not regd for SSTs \\
\hline Org Methods Dev (PNL) & W & & & & & & & & done under $103-5 Y$ \\
\hline Start-Up NeH MSMS (PML) & w & & & & & & & & done under 101-5Y \\
\hline Dev Methods for HSMS (PML) & N & & & & & & & & done under 101-5Y \\
\hline Physical Prop Methods Der & $M$ & & & & & & & & done under $103-5 Y$ \\
\hline Physical Modeling (PNL) & $\gamma$ & & & & $x$ & & & & \\
\hline Gas Flow Modeling & $y$ & & & & $x$ & & & & \\
\hline Thermal Sehavior & N & & & & & & & & complete under AM farm \\
\hline \multicolumn{10}{|l|}{ IS0133 Close USO/Resolve SI } \\
\hline Tech Suppt USQ/WL sereening & M & & & & & & & & done under $103-5 Y$ \\
\hline USa Database Report & N & & & & & & & & complete under aN farm \\
\hline Hazard Assessment & $y$ & & & & $x$ & & & & \\
\hline Safety Documentation & $r$ & & & & $x$ & $x$ & & & \\
\hline EAS & $\bar{\gamma}$ & & & & $x$ & & & & \\
\hline Hydrogen Burn Analysis & $y$ & & & & & $x$ & & & \\
\hline ISB/Cloge USQ & $\bar{Y}$ & & & & & $x$ & & & \\
\hline S1 Resolution & $r$ & & & & & & $x$ & & after monitoring upgrds \\
\hline \multicolumn{10}{|l|}{ TS0121 Monitoring Upgrades } \\
\hline Riser/Window Planning & $\bar{\gamma}$ & & & & & $x$ & & & \\
\hline Gas Monitoring (SHMS) & $Y$ & & & & & $x$ & & & \\
\hline Repair Existing TCS & $Y$ & $x$ & & & & & & & \\
\hline MITS & $\bar{Y}$ & & & & & & $x$ & & \\
\hline TMACS & $Y$ & & $x$ & & & & & & by Organic Program \\
\hline surface Level & $Y$ & & & & & & $x$ & & \\
\hline TV Camera & 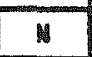 & & & & & & & & \\
\hline Ventilation & $Y$ & & & & & $x$ & & & \\
\hline Permitting/MEPA & $\bar{\gamma}$ & & & & & $\bar{x}$ & & & \\
\hline Density Trees & $M$ & & & & & & & & \\
\hline
\end{tabular}


Table 6-1. Work Activities for the Flammable Gas Tank Safety Program.

\begin{tabular}{|c|c|c|c|c|c|c|c|c|c|}
\hline \multirow{2}{*}{ MORK JOS } & \multirow{2}{*}{ RECD } & \multicolumn{6}{|c|}{-... MEEDED IN FISCAL YEAR ....... } & \multirow{2}{*}{$\begin{array}{c}\text { JOS } \\
\text { COMPLETE }\end{array}$} & \multirow{2}{*}{ COAMENTS } \\
\hline & & 94 & 95 & 96 & 97 & 98 & 99 & & \\
\hline Lightning Protection & H & & & & & & & & \\
\hline Misc if upgrades & H & & & & & & & & \\
\hline Equip enovl/oispos//storage & $\varphi$ & & & & & $x$ & & & \\
\hline \multicolumn{10}{|l|}{ Ts0122 Mitigation } \\
\hline Technology Dev/Model ing & W & & & & & & & & mitigation not regd \\
\hline Hitigation Test & M & & & & & & & & "19 \\
\hline Design & U & & & & & & & & 8 \\
\hline SA/EA & 愔 & & & & & & & & en \\
\hline Procure/fab & W & & & & & & & & 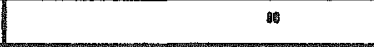 \\
\hline Window Mork/Install & v & & & & & & & & "8 \\
\hline \multicolumn{10}{|c|}{ TAK } \\
\hline \multicolumn{10}{|l|}{ Ts010s Evaluate Define } \\
\hline Auger Sampling/Analysis & $\forall$ & & & & & & & & crugt doesn't trap gas \\
\hline Core sempl ing/Analysis (NG) & $\gamma$ & & & & $x$ & $x$ & & & \\
\hline Data Interpretation & $y$ & & & & & $x$ & & & \\
\hline Vapor Sempling & $Y$ & & & & $x$ & & & & \\
\hline Vapor Analysis w/HSMS (PNL) & $\gamma$ & & & & & $x$ & & & \\
\hline In-Tank/field Hork & $\gamma$ & & & & & $x$ & & & \\
\hline GRE Reports & M & & & & & & & & no gas release events \\
\hline Gas Anelysis Reports & $Y$ & & & & & $x$ & & & \\
\hline In-Situ Gas Sampling & $N$ & & & & & & & & dev under $104=A M$ \\
\hline Waste Behar Data Eval (PML) & $Y$ & & & & & $x$ & & & \\
\hline \multicolumn{10}{|l|}{ T\$0105 Technology for Eval } \\
\hline Radiolytic Mecranisms (AML) & $N$ & & & & & & & & done under 101-5Y \\
\hline Chemical Mech (GIT/Other) & $H$ & & & & & & & & not regd for SSTs \\
\hline Gas Generation (UHC/TBO) & H & & & & & & & & not regd for SSTs \\
\hline Synthetic Studies (PNL) & M & & & & & & & & not regd for SsTs \\
\hline Org Methods DeV (PML) & N & & & & & & & & done under $103-5 Y$ \\
\hline Start-Up MeW HSAS (PML) & M & & & & & & & & done under $101.5 Y$ \\
\hline Dev Methods for HSMS (PNL) & $M$ & & & & & & & & done under $101.5 Y$ \\
\hline Physical Prop Methods Dev & N & & & & & & & & don: under $103-5 Y$ \\
\hline Physical modeling (PNL) & 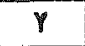 & & & & $x$ & & & & \\
\hline Gas Flow Model ing & $Y$ & & & & $x$ & & & & \\
\hline Thermal Behavior & H & & & & & & & & complete under AN farm \\
\hline \multicolumn{10}{|l|}{ TSO133 close USQ/Resolve SI } \\
\hline Tech Suppt USA/WL Screening & $N$ & & & & & & & & done under $103-5 Y$ \\
\hline USa Databese Report & N & & & & & & & & complete under AN farm \\
\hline Hazard Assessment & $Y$ & & & & $x$ & & & & \\
\hline Safery Documentation & $Y$ & & & & $x$ & $x$ & & & \\
\hline EAీ & $Y$ & & & & $x$ & & & & \\
\hline Hydrogen Burn Analysis & $Y$ & & & & & $x$ & & & \\
\hline ISB/Close USO & $Y$ & & & & & $x$ & & & \\
\hline S1 Resolution & $Y$ & & & & & & $x$ & & after monitoring upgrds \\
\hline
\end{tabular}


Table 6-1. Work Activities for the Flammable Gas Tank Safety Program.

\begin{tabular}{|c|c|c|c|c|c|c|c|c|c|}
\hline \multirow{2}{*}{ WORK JOE } & \multirow{2}{*}{ MEQ } & \multicolumn{6}{|c|}{ 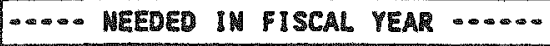 } & \multirow{2}{*}{$\begin{array}{c}\text { JOS } \\
\text { COMPLETE }\end{array}$} & \multirow{2}{*}{ COMMEMTS } \\
\hline & & 94 & 95 & 96 & 97 & 98 & 99 & & \\
\hline \multicolumn{10}{|l|}{ Ts0121 Monitoring Upgrades } \\
\hline Riser/Windos Planning & $Y$ & & & & & $x$ & & & \\
\hline Gas Moni toring (shMS) & $Y$ & & & & & $x$ & & & \\
\hline Repair Existing TCS & 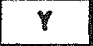 & $x$ & & & & & & & \\
\hline MITs & $\varphi$ & & & & & & $x$ & & \\
\hline TMACS & 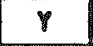 & & $x$ & & & & & & by Organic Program \\
\hline Surface Level & $Y$ & & & & & & $x$ & & \\
\hline TV Camera & $M$ & & & & & & & & \\
\hline Ventilation & $Y$ & & & & & $x$ & & & \\
\hline Permi tring/NEPA & $Y$ & & & & & $x$ & & & \\
\hline Denaity Trees & H & & & & & & & & \\
\hline Lightring Protection & 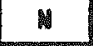 & & & & & & & & \\
\hline Wiac if Upgrades & H & & & & & & & & \\
\hline Equip Removl/oispos//storage & $\gamma$ & & & & & $x$ & & & \\
\hline \multicolumn{10}{|l|}{ TS0122 Mitigation } \\
\hline Technology Dev/Model ing & $M$ & . & & & & & & & Imitigation not"regd \\
\hline Mitigation Test & N & & & & & & & & 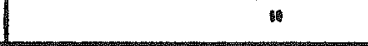 \\
\hline Des ign & H & & & & & & & & 8 \\
\hline SA/EA & M & & & & & & & & at \\
\hline Procure/frab & M & & & & & & & & 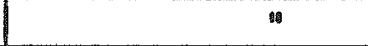 \\
\hline Window Hork/Instal! & H & & & & & & & & a \\
\hline \multicolumn{10}{|c|}{ TANHK TOS.5 } \\
\hline \multicolumn{10}{|l|}{ iso103 Evoluate \& Define } \\
\hline Auger Sampling/Analys is & n & & & & & & & & crust doesn't trap gas \\
\hline Core Sampling/Analys is (Mm) & $Y$ & & & & $x$ & $x$ & & & \\
\hline Data Interpretation & $\gamma$ & & & & & $x$ & & & \\
\hline Vapor sampling & $\Upsilon$ & & & & $x$ & & & & \\
\hline Vapor Analysis H/HSMS (PML) & $Y$ & & & & & $x$ & & & \\
\hline In-Tank/field Work & $Y$ & & & & & $x$ & & & \\
\hline GRE Reports & M & & & & & & & & no gas release events \\
\hline Gas Analysis Reports & $\varphi$ & & & & & $x$ & & & \\
\hline In-Situ Gas Sampling & H & & & & & & & & dev under 104-AM \\
\hline Waste Behav Data Eval (PML) & $Y$ & & & & & $x$ & & & \\
\hline \multicolumn{10}{|l|}{ TS0105 Technology for Eval } \\
\hline Radiolytic Mechanisns (AML) & $N$ & & & & & & & & done under 101-5r \\
\hline Chemical Mech (GIT/Other) & $N$ & & & & & & & & not regd for SSTs \\
\hline Gas Generation (WHC/TBD) & $H$ & & & & & & & & not regd for SSTS \\
\hline Synthetic studies (PNL) & $M$ & & & & & & & & not regd for SSTs \\
\hline Org Hethods Dev (PML) & M & & & & & & & & done under $103-5 Y$ \\
\hline Start-Up New HSAS (PNL) & $M$ & & & & & & & & done under 101-5Y \\
\hline Dev Methods for HSMS (PML) & $M$ & & & & & & & & done under 101-5Y \\
\hline Physical Prop Methods Dey & H & & & & & & & & done under 103-5Y \\
\hline Physical Modeling (PNL) & $\gamma$ & & & & $x$ & & & & \\
\hline
\end{tabular}


Table 6-1. Work Activities for the Flammable Gas Tank Safety Program.

\begin{tabular}{|c|c|c|c|c|c|c|c|c|c|}
\hline \multirow{2}{*}{ HORK JOS } & \multirow{2}{*}{ REOO } & \multicolumn{6}{|c|}{ 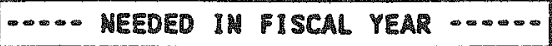 } & \multirow{2}{*}{$\begin{array}{c}\text { JOS } \\
\text { COMPLETE }\end{array}$} & \multirow{2}{*}{ COMMENTS } \\
\hline & & 94 & 95 & 86 & 87 & 98 & 99 & & \\
\hline Gas Flow Modeling & $Y$ & & & & $x$ & & & & \\
\hline Thermal Behavior & H & & & & & & & & complete under AN farm \\
\hline \multicolumn{10}{|l|}{ Tso133 close Usa/Resolve \$I } \\
\hline Tech Suppt USQ/WL Screening & M & & & & & & & & done under 103-5Y \\
\hline USa Database Report & y & & & & & & & & complete under AM farm \\
\hline Hazard Assessment & $\varphi$ & & & & $x$ & & & & \\
\hline Safery Documentation & $Y$ & & & & $x$ & $x$ & & & \\
\hline EAs & $P$ & & & & $x$ & & & & \\
\hline Hydrogen Burn Anelysis & $Y$ & & & & & $x$ & & & \\
\hline IS8/Close UsQ & $\gamma$ & & & & & $x$ & & & \\
\hline SI Resolution & $\gamma$ & & & & & & $x$ & & after monitoring upgrds \\
\hline \multicolumn{10}{|l|}{ PS0121 Monitoring Upgrades } \\
\hline Riser/Mindow Planning & $\gamma$ & & & & & $x$ & & & \\
\hline Gas Monitoring (sHMS) & $Y$ & & & & & $x$ & & & \\
\hline Repair Existing TCs & $\gamma$ & $x$ & & & & & & & \\
\hline MITs & $Y$ & & & & & & $x$ & & \\
\hline TMACS & $Y$ & & $x$ & & & & & & by Organic Program \\
\hline Surface Level & $Y$ & & & & & & $x$ & & \\
\hline TV Camera & M & & & & & & & & \\
\hline Ventilation & $\varphi$ & & & & & $x$ & & & \\
\hline Permitting/MEPA & $Y$ & & & & & $x$ & & & \\
\hline Density Trees & M & & & & & & & & \\
\hline Lighening Protection & $N$ & & & & & & & & \\
\hline Misc Tf Upgrades & M & & & & & & & & \\
\hline Equip Renovl/o ispos l/storage & $y$ & & & & & $x$ & & & \\
\hline \multicolumn{10}{|l|}{ TS0122 Mitigation } \\
\hline Technology Dev/Model ing & N & & & & & & & & mitigation not read \\
\hline Mitigation Test & t & & & & & & & & 3日 \\
\hline Design & 躍 & & & & & & & & " \\
\hline SA/EA & H & & & & & & & & a \\
\hline Procure/Fab & 嘈 & & & & & & & & se \\
\hline Window Hork/Install & * & & & & & & & & 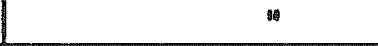 \\
\hline \multicolumn{10}{|c|}{ 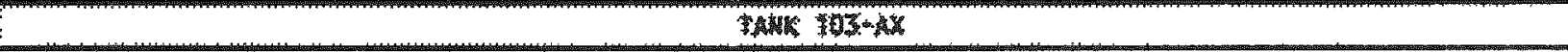 } \\
\hline \multicolumn{10}{|l|}{ TS0103 Evaluate \& Derine } \\
\hline Auger Sampling/Analys is & H & & & & & & & & crust doesn't trap gas \\
\hline Core Sampling/Analys is (NA) & $r$ & & & & $x$ & $x$ & & & \\
\hline Data Interpratation & $Y$ & & & & & $x$ & & & \\
\hline Vapor Sampl ing & $r$ & & & & $x$ & & & & \\
\hline Vapor Analys is w/HSMS (PNL) & $Y$ & & & & & $x$ & & & \\
\hline In-Tank/Field Work & $Y$ & & & & & $x$ & & & \\
\hline GRE Reports & $H$ & & & & & & & & no gas relese events \\
\hline Gas Analysis Reports & $Y$ & & & & & $x$ & & & \\
\hline In-Situ Gas Sampling & $M$ & & & & & & & & dev under $104-\mathrm{AN}$ \\
\hline
\end{tabular}


Table 6-1. Work Activities for the Flammable Gas Tank Safety Program.

\begin{tabular}{|c|c|c|c|c|c|c|c|c|c|}
\hline \multirow{2}{*}{ WORK JOS } & \multirow{2}{*}{ RECO } & \multicolumn{2}{|c|}{$\ldots-\ldots$ MEEDED } & \multicolumn{2}{|c|}{ IN FISCAL } & \multicolumn{2}{|c|}{ YEAR $\cdots \infty-\infty \cdots 0$} & \multirow{2}{*}{$\begin{array}{c}\text { JOB } \\
\text { COMPLETE }\end{array}$} & \multirow{2}{*}{ COAMENTS } \\
\hline & & 94 & 95 & 96 & 97 & 98 & 99 & & \\
\hline Wast Behav Data Eval (PML) & $Y$ & & & & & $x$ & & & \\
\hline \multicolumn{10}{|l|}{ Tso10s Technology for Eval } \\
\hline Rediolytic Mechanisms (AML) & 1 & & & & & & & & done under $101.5 Y$ \\
\hline Chemical Mech (GIT/Other) & 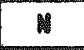 & & & & & & & & not regd for SSTs \\
\hline Gas Generation (HHC/TBD) & $M$ & & & & & & & & not regd for SSTs \\
\hline Synthetic Studies (PNL) & M & & & & & & & & not regd for SSTs \\
\hline Org Methods Dev (PNL) & $M$ & & & & & & & & done under $103-5 Y$ \\
\hline Start-UP New MSMS (PML) & $M$ & & & & & & & & done under $101-5 y$ \\
\hline Dev Methods for HSMS (PML) & $y$ & & & & & & & & done under 101-5Y \\
\hline Physical Prop Methods Dey & M & & & & & & & & done under $103-5 Y$ \\
\hline Physical Model ing (PML) & $\varphi$ & & & & $x$ & & & & \\
\hline Gas flow Model ing & $Y$ & & & & $x$ & & & & \\
\hline Thermal Behavior & N & & & & & & & & complete under All farm \\
\hline \multicolumn{10}{|l|}{ Tso133 Close UsQ/Resolve SI } \\
\hline Tech suppt USQ/ML Screening & $M$ & & & & & & & & done under 103-5Y \\
\hline USa Database Report & W & & & & & & & & compl ete under AM farm \\
\hline Hazard Assessment & $\gamma$ & & & & $x$ & & & & \\
\hline Safety Documentation & $\gamma$ & & & & $x$ & $x$ & & & \\
\hline EAS & $\gamma$ & & & & $x$ & & & & \\
\hline Hydrogen Burn Analysis & $\mathbf{Y}$ & & & & & $x$ & & & \\
\hline Is8/Close use & $Y$ & & & & & $x$ & & & \\
\hline S1 Resolution & $\gamma$ & & & & & & $x$ & & after monitoring upgrds \\
\hline \multicolumn{10}{|l|}{ T50121 Monitoring Upgrades } \\
\hline Riser/Mindow Planning & $Y$ & & & & & $x$ & & & \\
\hline Gas Monitoring (SHMS) & $Y$ & & & & & $x$ & & & \\
\hline Repair Existing TCs & $Y$ & $x$ & & & & & & & \\
\hline MITS & $Y$ & & & & & & $\bar{x}$ & & \\
\hline TMACS & 1 & & & $x$ & & & & & \\
\hline surface Level & $\gamma$ & & & & & & $x$ & & \\
\hline TV Canera & w & & & & & & & & \\
\hline Ventilation & $Y$ & & & & $x$ & & & & \\
\hline Permitting/NEPA & 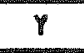 & & & & $x$ & & & & \\
\hline Density Trees & M & & & & & & & & \\
\hline Lightning Protection & $M$ & & & & & & & & \\
\hline Mise if Upgrades & $M$ & & & & & & & & \\
\hline Equip Removl/Disposl/storage & $\gamma$ & & & & & & $x$ & & \\
\hline \multicolumn{10}{|l|}{ Ts0122 Mitigation } \\
\hline Technology Dev/Model ing & $n$ & & & & & & & & mitigation not reqd \\
\hline Mitigation Test & $M$ & & & & & & & & 18 \\
\hline Design & M & & & & & & & & "1 \\
\hline SA/EA & M & & & & & & & & "11 \\
\hline Procure/fab & M & & & & & & & & : \\
\hline Windom Work/Instal! & 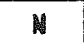 & & & & & & & & 18 \\
\hline
\end{tabular}




\subsection{REFERENCES}

DOE, 1986, Safety of Nuclear Facilities, DOE Order 5480.5, U.S. Department of Energy, Washington, D.C.

Lentsch, J. W., 1992, Tank 101-SY Flammable Gas Mitigation Test Project Plan, WHC-EP-0550, Westinghouse Hanford Company, Richland, Washington.

"Safety Measures for Waste Tanks at Hanford Nuclear Reservation," Section 3137 of National Defense Authorization Act for Fiscal Year 1991, Public Law 101-510, November 5, 1990. 
WHC-SD-WM-SD-019 Rev. 0

This page intentionally left blank. 
APPENDIX A

PROGRAM DRIVERS

A-1 
WHC-SD-WM-SD-019 Rev。 0

This page intentionally left blank. 


\section{APPENDIX A}

\section{PROGRAM DRTVERS}

Several government "requirements" have resulted in the Flammable Gas Tank Safety Program. These program drivers are discussed here.

\section{SAFETY MEASURES LAW}

Concern for radioactive liquid waste tank safety at the Hanford Site was sufficient to cause the U.S. Congress to pass Public Law 101-510, Section 3137, "Safety Measures for Waste Tanks at Hanford Nuclear Reservation" (the Safety Measures Law). This law requires the following actions:

- Identify tanks that "...may have a serious potential for release of high-level waste due to uncontrolled increases in temperature or pressure ..."

- Ensure that "... continuous monitoring to detect a release or excessive temperature or pressure ..." is carried out

- "... develop action plans to respond to excessive temperature or pressure or a release from any tank identified ..."

- Restrict additions of high-level nuclear wastes to the identified tanks unless no safer alternative exists or the serious potential for a release of high-level nuclear waste is no longer a threat

- Report "... on actions taken to promote tank safety, including actions specifically taken pursuant to this section of the law, and the... timetable for resolving the outstanding issues on how to handle the waste in such tanks."

The Waste Tank Safety Program is the key element in responding to this law. 


\section{ATOMIC ENERGY ACT OF 1954}

The orders listed below involve the management of waste containing radioactivity Department of Energy (DOE) under the Atomic Energy Act of 1954, as amended by Public Law 83-703.

- DOE Order 5820.2A, Radioactive Waste Management

- DOE Order 5480.1B, Environmental, Safety, and Health Program for Department of Energy Operations

- DOE Order 5480.21, Unreviewed Safety Questions

- DOE Order 5481.1B, Safety Analysis and Review System

- DOE Order 6430.1A, General Design Criteria.

\section{CODE OF FEDERAL REGULATIONS}

- 10 CFR 962, "Radioactive Waste: Byproduct Material"

- 10 CFR 1021, "Department of Energy NEPA Implementing Procedures"

- $\quad 40$ CFR 191, Environmental Radiation Protection Standards for Management and Disposal of Spent Nuclear Fuel, High-Level and Transuranic Radioactive Wastes"

- 40 CFR 261, "Identification and Listing of Hazardous Waste"

- 40 CFR 262, "Standards Applicable to Generators of Hazardous Waste"

- $\quad 40$ CFR 1500-1508, "Regulations for Implementing the Procedural Provisions of the National Environmental Policy Act."

\section{UNREVIEWED SAFETY QUESTION}

The safety issue of flammable gas generation and release has been identified as an unreviewed safety question (USQ). The safety issue was identified as an USQ because it "represents conditions outside the identified safety envelope" according to Westinghouse Hanford Management Requirement and Procedure 5.12, "Identification and Resolution of Unreviewed Safety Questions," Management Requirements and Procedures Manual (WHC-CH-1-3). 


\section{WASHINGTON ADMINISTRATIVE CODE}

Waste Tank Safety Programs activities must comply with the State of Washington Administrative Codes (WAC) for managing dangerous waste. The specific regulation is WAC 173-303, Section 110, "Dangerous Waste Regulations."

\section{DEFENSE NUCLEAR FACUITUES SAFETY BOARD}

The Defense Nuclear Facilities Safety Board was created to provide advice and formal recommendations to the President and the Secretary of Energy regarding public health and safety issues at DOE nuclear facilities. The board reviews operations practices and occurrences at DOE nuclear facilities and makes appropriate recommendations to protect public health and safety. In the event that any aspect of operations, practices, or occurrences reviewed by the board is determined to present an imminent or severe threat to public health or safety, the board transmits its recommendations directly to the President.

\section{REFERENCES}

Atomic energy Act of 1954, as amended, Public Law 83-703, 66 Stat.919, 42 USC 20H.

DOE, 1986, Safety Analysis and Review System, DOE Order 5481.B, U.S. Department of Energy, Washington, D.C.

DOE, 1988, Environmental, Safety, and Health Program for Department of Energy Operations, DOE Order 5480.1B, U.S. Department of energy, Washington, D.C.

DOE, 1989, General Design Criteria, DOE Order 6430.1A, U.S. Department of Energy, Washington; D.C.

DOE, 1990, Radiation Waste Management, DOE Order 5820.2A, U.S. Department of Energy, Washington, D.C.

DOE, 1991, Unreviewed Safety Questions, DOE Order 5480.21, U.S. Department of Energy, Washington, D.C.

Ecology, 1991, Dangerous Waste Regulations, Washington Administrative Code 173-303, Washington State Department of Ecology, Olympia, Washington.

EPA, 1987, Identification and listing of Hazardous Waste, Title 40, Code of Federal Regulations, Part 261, U.S. Environmental Protection Agency, Washington, D.C. 
"Safety Measures for Waste Tanks at Hanford Nuclear Reservation," Section 3137 of National Defense Authorization Act for Fiscal Year 1991, Public Law 101-510, November 5, 1990.

WHC-CM-1-3, Management Requirements and Procedures Manual, Westinghouse Hanford Company, Richland, Washington. 